\title{
Influenza Vaccination Coverage Among Health Care Personnel - United States, 2014-15 Influenza Season
}

\begin{abstract}
Carla L. Black, $\mathrm{PhD}^{1}$; Xin Yue, MPS, MS ${ }^{1}$; Sarah W. Ball, ScD 2 ; Sara M.A. Donahue, $\mathrm{DrPH}^{2}$; David Izrael, $\mathrm{MS}^{2}$; Marie A. de Perio, MD 3 ; A. Scott Laney, PhD ${ }^{4}$; Walter W. Williams, MD ${ }^{1}$; Megan C. Lindley, $\mathrm{MPH}^{1}$; Samuel B. Graitcer, MD ${ }^{1}$; Peng-jun Lu, MD, PhD ${ }^{1}$; Carolyn B. Bridges, $\mathrm{MD}^{1}$; Charles DiSogra, DrPH${ }^{5}$; John Sokolowski, MA5; Deborah K. Walker, EdD²; Stacie M. Greby, DVM ${ }^{1}$
\end{abstract}

The Advisory Committee on Immunization Practices recommends annual influenza vaccination for all health care personnel (HCP) to reduce influenza-related morbidity and mortality among both HCP and their patients and to decrease absenteeism among HCP (1-5). To estimate influenza vaccination coverage among U.S. HCP for the 2014-15 influenza season, CDC conducted an opt-in Internet panel survey of 1,914 HCP during March 31-April 15, 2015. Overall, 77.3\% of HCP survey participants reported receiving an influenza vaccination during the 2014-15 season, similar to the $75.2 \%$ coverage among HCP reported for the 2013-14 season (G). Vaccination coverage was highest among HCP working in hospitals (90.4\%) and lowest among HCP working in longterm care (LTC) settings (63.9\%). By occupation, coverage was highest among pharmacists $(95.3 \%)$ and lowest among assistants and aides (64.4\%). Influenza vaccination coverage was highest among HCP who were required by their employer to be vaccinated (96.0\%). Among HCP without an employer requirement for vaccination, coverage was higher for HCP working in settings where vaccination was offered on-site at no cost for 1 day (73.6\%) or multiple days (83.9\%) and lowest among HCP working in settings where vaccine was neither required, promoted, nor offered on-site (44.0\%). Comprehensive vaccination strategies that include making vaccine available at no cost at the workplace along with active promotion of vaccination might help increase vaccination coverage among HCP and reduce the risk for influenza to HCP and their patients $(1,6,7)$.

The opt-in Internet panel survey was conducted for CDC by Abt Associates, Inc. (Cambridge, Massachusetts) during March 31-April 15, 2015, to provide estimates of influenza vaccination coverage among HCP during the 2014-15 influenza season. Two preexisting national opt-in Internet sources were used to recruit HCP for the survey. Professional clinical HCP (physicians, nurse practitioners, physician assistants, nurses, dentists, pharmacists, allied health professionals, technicians, and technologists) were recruited from the current membership roster of Medscape, a medical website managed by WebMD Health Professional Network.* Medscape's terms of service explicitly permit WebMD Professional Network to contact members about programming, including survey research; members receive an honorarium for completing surveys. HCP in other occupations (e.g., assistants, aides, and nonclinical personnel such as administrators, clerical support

*Additional information on Medscape is available at http://www.medscape.com.

\section{INSIDE}

1000 Influenza Vaccination Coverage Among Pregnant Women — United States, 2014-15 Influenza Season

1006 Clinical Inquiries Received by CDC Regarding Suspected Ebola Virus Disease in Children United States, July 9, 2014-January 4, 2015

1011 Update: Influenza Activity — United States and Worldwide, May 24-September 5, 2015

1017 Announcements

1019 Notice to Readers: Final 2014 Reports of Nationally Notifiable Infectious Diseases

1034 QuickStats

Continuing Education examination available at http://www.cdc.gov/mmwr/cme/conted_info.html\#weekly.

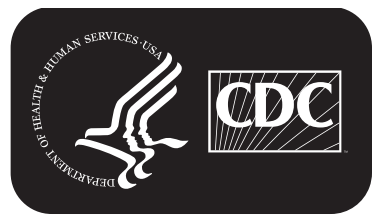

U.S. Department of Health and Human Services Centers for Disease Control and Prevention 
workers, janitors, food service workers, and housekeepers) who met eligibility criteria were recruited for a health survey from general population Internet panels operated by Survey Sampling International (SSI) that provide panel members with online survey opportunities in exchange for nominal incentives. $^{\dagger} \mathrm{HCP}$ were recruited through e-mails and messages on the list or panel websites and were eligible for the survey if they reported working in at least one of eight health care settings or reported any patient contact.

Survey elements included demographic characteristics, occupation, work setting, self-reported influenza vaccination, and employer vaccination policies (i.e., vaccination requirements, vaccination availability at the workplace, and promotion of vaccination including recognition, rewards, reminders, compensation, and free or subsidized vaccination). Survey responses were used to categorize HCP into seven occupation and four work setting groups for this analysis. The occupation types were 1) physicians, 2) nurse practitioners/physician assistants, 3) nurses, 4) pharmacists, 5) assistants/aides, 6) other clinical HCP, ${ }^{\S}$ and 7) nonclinical HCP. The work settings were: 1) hospitals, 2) ambulatory care/physician offices, 3) LTC

\footnotetext{
${ }^{\dagger}$ Additional information on Survey Sampling International and its incentives for online survey participants is available at https://www.surveysampling.com.

$\S$ Other clinical HCP included allied health professionals, technicians, and technologists.
}

settings, and 4) other clinical settings. Respondents could specify working in more than one work setting. Responses were weighted to the distribution of the U.S. population of HCP by occupation, age, sex, race/ethnicity, work setting, and census region. ${ }^{* *}$ Vaccination coverage estimates from opt-in Internet panel surveys conducted during the 2010-11 through 2014-15 influenza seasons were compared with assess trends over time. Similar methodology was used for all five influenza seasons, although Internet panels used to recruit both clinical and nonclinical HCP in 2010-11 differed from those used in subsequent years (G). Because the study sample was based on HCP from opt-in Internet panels rather than probability samples, no statistical tests were performed. ${ }^{\dagger \dagger}$ A change was

\footnotetext{
I Ambulatory care/physician's office included physicians' offices, medical clinics, and other nonhospital outpatient or ambulatory care settings. LTC settings included nursing homes, home health agencies, home health care settings, assisted living facilities, or other LTC settings. Other clinical settings included dental offices or clinics, pharmacies, laboratories, public health settings, health care education settings, emergency medical services settings, or other settings where clinical care or related services were provided to patients.

** Population control totals of U.S. HCP by occupation and work setting were obtained from the Bureau of Labor Statistics, U.S. Department of Labor, Occupational Employment Statistics, May 2013 National Industry-specific Occupational Employment and Wage Estimates (available at http://www.bls. gov/oes/current/oessrci.htm). Population control totals by other demographic characteristics were obtained from the U.S. Census Bureau, Current Population Survey Monthly Labor Force Data, September 2014 (available at http://www. census.gov/cps/data).

$\dagger \dagger$ Additional information on obstacles to inference in non-probability samples is available at http://www.aapor.org/AAPORKentico/AAPOR_Main/media/ MainSiteFiles/NPS_TF_Report_Final_7_revised_FNL_6_22_13.pdf.
}

The MMWR series of publications is published by the Center for Surveillance, Epidemiology, and Laboratory Services, Centers for Disease Control and Prevention (CDC), U.S. Department of Health and Human Services, Atlanta, GA 30329-4027.

Suggested citation: [Author names; first three, then et al., if more than six.] [Report title]. MMWR Morb Mortal Wkly Rep 2015;64:[inclusive page numbers].

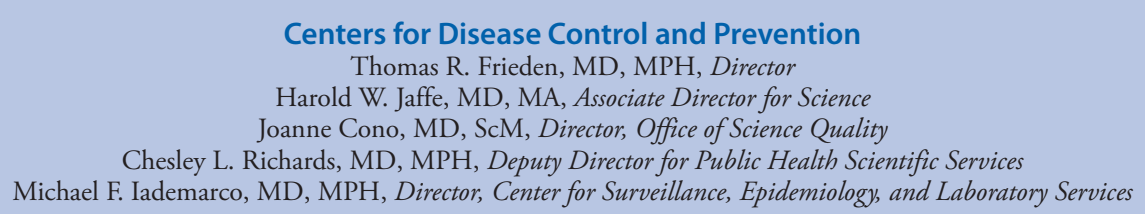

MMWR Editorial and Production Staff (Weekly)

Sonja A. Rasmussen, MD, MS, Editor-in-Chief

Charlotte K. Kent, PhD, MPH, Executive Editor Jacqueline Gindler, MD, Editor

Teresa F. Rutledge, Managing Editor

Douglas W. Weatherwax, Lead Technical Writer-Editor

Teresa M. Hood, MS, Jude C. Rutledge, Writer-Editors

\section{MMWR Editorial Board}

Timothy F. Jones, MD, Nashville, TN, Chairman

Matthew L. Boulton, MD, MPH, Ann Arbor, MI

Virginia A. Caine, MD, Indianapolis, IN

Jonathan E. Fielding, MD, MPH, MBA, Los Angeles, CA

David W. Fleming, MD, Seattle, WA

William E. Halperin, MD, DrPH, MPH, Newark, NJ
Martha F. Boyd, Lead Visual Information Specialist

Maureen A. Leahy, Julia C. Martinroe, Stephen R. Spriggs, Brian E. Wood, Visual Information Specialists Quang M. Doan, MBA, Phyllis H. King, Teresa C. Moreland, Terraye M. Starr Information Technology Specialists

King K. Holmes, MD, PhD, Seattle, WA Rima F. Khabbaz, MD, Atlanta, GA Patricia Quinlisk, MD, MPH, Des Moines, IA Patrick L. Remington, MD, MPH, Madison, WI William L. Roper, MD, MPH, Chapel Hill, NC William Schaffner, MD, Nashville, TN 
FIGURE. Percentage of health care personnel* (HCP) who reported receiving influenza vaccination, by work setting and occupation type Internet panel surveys, United States, 2010-11 through 2014-15 influenza seasons
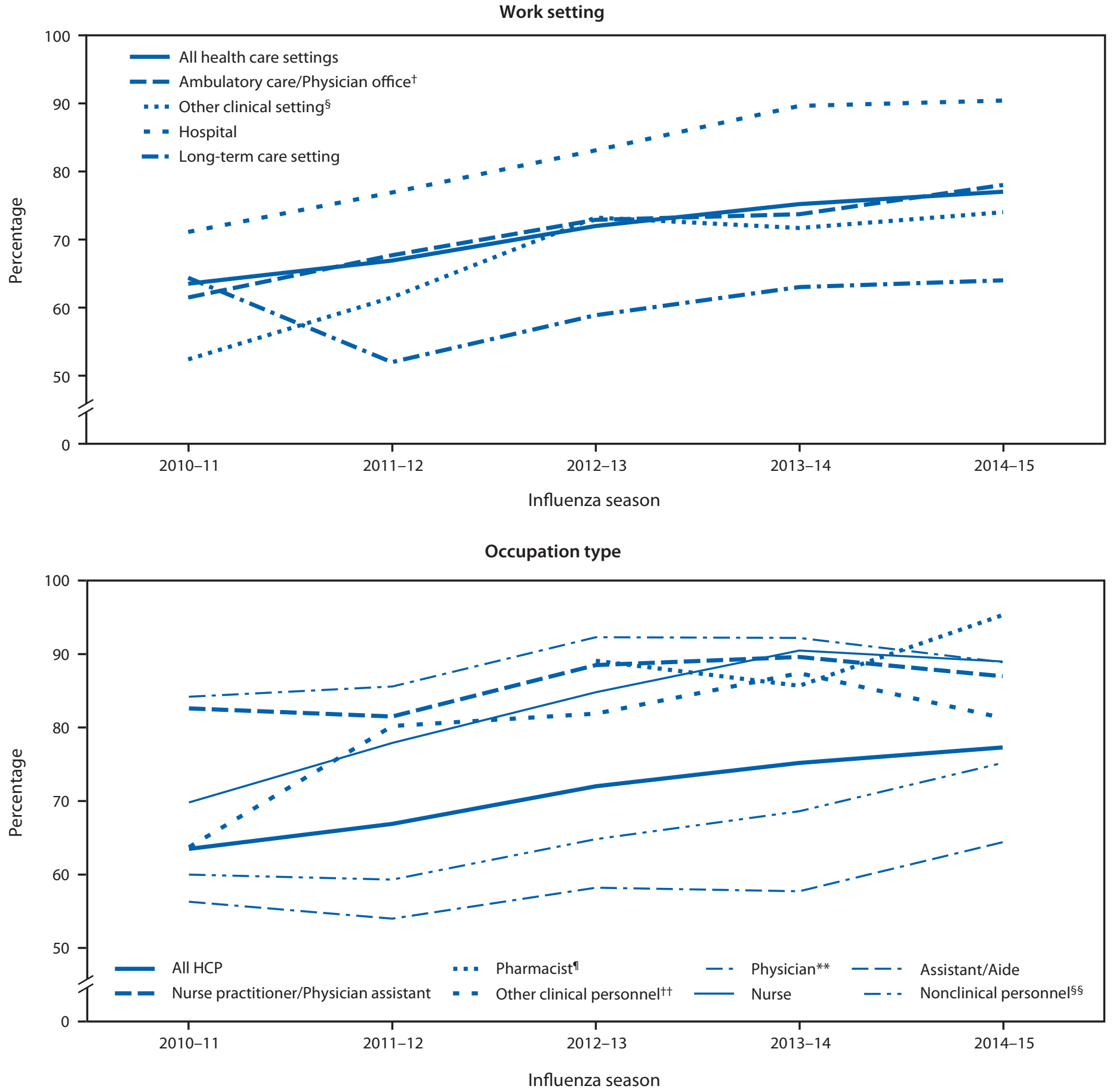

\footnotetext{
* Persons who worked in a place where clinical care or related services were provided to patients, or whose work involved face-to-face contact with patients or who were ever in the same room as patients.

† Ambulatory care (physician's office, medical clinic, and other ambulatory care setting).

$\S$ Dentist office or dental clinic, pharmacy, laboratory, public health setting, health care education setting, emergency medical services setting, or other setting where clinical care or related services was provided to patients.

I Individual data on pharmacists were not collected before the 2012-13 season.

** Included dentists in 2010-11 season.

${ }^{t \dagger}$ Allied health professionals, technicians, and technologists.

$\S \S$ Administrative support staff members or manager and nonclinical support staff members (including food service workers, laundry workers, janitors, and members of the housekeeping and maintenance staffs).
} 
TABLE 1. Percentage of health care personnel ${ }^{*}(\mathrm{HCP})$ who reported receiving influenza vaccination, by work setting and occupation type Internet panel surveys. United States, 2013-14 and 2014-15 influenza seasons

\begin{tabular}{|c|c|c|c|c|c|c|c|}
\hline \multirow[b]{2}{*}{$\begin{array}{l}\text { Work setting/ } \\
\text { Occupation type }\end{array}$} & \multicolumn{3}{|c|}{ 2013-14 influenza season } & \multicolumn{3}{|c|}{ 2014-15 influenza season } & \multirow{2}{*}{$\begin{array}{c}\text { Percentage point } \\
\text { difference from } \\
2013-14 \text { to } 2014-15\end{array}$} \\
\hline & No. & Weighted \%§ & $\begin{array}{l}\text { Weighted } \% \\
\text { vaccinated }\end{array}$ & No. & Weighted \%§ & $\begin{array}{l}\text { Weighted } \% \\
\text { vaccinated }\end{array}$ & \\
\hline Overall & 1,882 & 100 & 75.2 & 1,914 & 100 & 77.3 & 2.1 \\
\hline Hospital & 880 & 40.8 & 89.6 & 681 & 40.4 & 90.4 & 0.8 \\
\hline Physician & 185 & 5.7 & 93.1 & 99 & 3.6 & 92.1 & -1.0 \\
\hline NP/PA & 42 & 0.8 & 97.6 & 61 & 0.9 & 93.4 & -4.2 \\
\hline Nurse & 125 & 27.5 & 94.7 & 70 & 22.1 & 93.4 & -1.3 \\
\hline Pharmacist & 28 & 1.2 & - & 65 & 2.6 & 96.1 & - \\
\hline Assistant/Aide & 19 & 7.2 & - & 51 & 9.8 & 85.8 & - \\
\hline Other clinical HCP** & 271 & 28.3 & 92.3 & 195 & 25.3 & 91.6 & -0.7 \\
\hline Nonclinical HCP ${ }^{\dagger \dagger}$ & 198 & 29.2 & 84.4 & 124 & 35.5 & 88.1 & 3.7 \\
\hline Ambulatory care /Physician office ${ }^{\S \S}$ & 649 & 28.0 & 73.7 & 746 & 30.2 & 78.4 & 4.7 \\
\hline Physician & 250 & 11.4 & 91.6 & 223 & 9.7 & 88.2 & -3.4 \\
\hline NP/PA & 98 & 2.6 & 89.8 & 114 & 2.3 & 85.1 & -4.7 \\
\hline Nurse & 56 & 19.4 & 82.2 & 69 & 23.4 & 90.8 & 8.6 \\
\hline Pharmacist & 9 & 0.8 & - & 6 & 0.3 & - & - \\
\hline Assistant/Aide & 11 & 6.7 & - & 27 & 5.8 & - & - \\
\hline Other clinical HCP** & 125 & 18.2 & 78.9 & 151 & 22.0 & 73.6 & -5.3 \\
\hline Nonclinical HCPt† & 90 & 40.7 & 62.7 & 142 & 36.2 & 70.4 & 7.7 \\
\hline Long-term care setting & 364 & 30.5 & 63.0 & 406 & 30.6 & 63.9 & 0.9 \\
\hline Physician & 19 & 0.8 & - & 26 & 1.3 & - & - \\
\hline NP/PA & 11 & 0.3 & - & 12 & 0.2 & - & - \\
\hline Nurse & 26 & 9.2 & - & 22 & 8.0 & - & - \\
\hline Pharmacist & 1 & 0.0 & - & 4 & 0.3 & - & - \\
\hline Assistant/Aide & 121 & 60.9 & 54.4 & 246 & 57.5 & 59.8 & 5.4 \\
\hline Other clinical HCP** & 47 & 6.2 & 89.4 & 45 & 6.6 & 78.4 & -11.0 \\
\hline Nonclinical HCP ${ }^{\dagger \dagger}$ & 139 & 22.6 & 66.4 & 50 & 26.0 & 67.3 & 0.9 \\
\hline Other clinical setting & 327 & 11.9 & 71.7 & 389 & 11.2 & 74.0 & 2.3 \\
\hline Physician & 8 & 0.9 & - & 6 & 0.7 & - & - \\
\hline NP/PA & 2 & 0.1 & - & 5 & 0.3 & - & - \\
\hline Nurse & 23 & 17.5 & - & 19 & 20.8 & - & - \\
\hline Pharmacist & 64 & 9.4 & 87.6 & 47 & 7.0 & 97.6 & 10.0 \\
\hline Assistant/Aide & 7 & 10.1 & - & 22 & 10.0 & - & - \\
\hline Other clinical HCP** & 167 & 27.0 & 82.0 & 249 & 31.3 & 73.5 & -8.5 \\
\hline Nonclinical $\mathrm{HCP}^{+\dagger}$ & 46 & 34.3 & 52.1 & 35 & 29.7 & 66.6 & 14.5 \\
\hline \multicolumn{8}{|l|}{ Overall occupation } \\
\hline Physician & 326 & 4.1 & 92.2 & 268 & 3.6 & 88.9 & -3.3 \\
\hline NP/PA & 125 & 0.9 & 89.6 & 162 & 1.0 & 87.0 & -2.6 \\
\hline Nurse & 203 & 18.7 & 90.5 & 161 & 18.3 & 89.0 & -1.5 \\
\hline Pharmacist & 75 & 1.3 & 85.7 & 79 & 1.3 & 95.3 & 9.6 \\
\hline Assistant/Aide & 152 & 23.6 & 57.7 & 332 & 23.3 & 64.4 & 6.7 \\
\hline Other clinical HCP** & 533 & 19.3 & 87.4 & 565 & 19.5 & 81.3 & -6.1 \\
\hline Nonclinical HCP+† & 445 & 31.9 & 68.6 & 322 & 32.8 & 75.2 & 6.6 \\
\hline
\end{tabular}

Abbreviations: $\mathrm{NP}=$ nurse practitioner; $\mathrm{PA}=$ physician assistant.

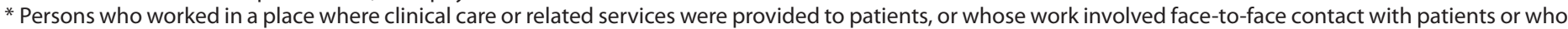
were ever in the same room as patients.

† Respondents could specify working in more than one setting.

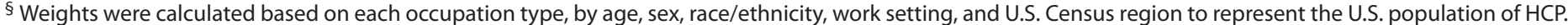

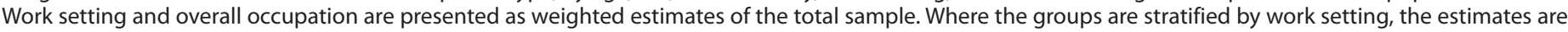
presented as weighted estimates of the occupation group subsample of each work setting subgroup.

I Vaccination coverage estimate not reliable because the sample size was $<30$.

** Allied health professional, technician, or technologist.

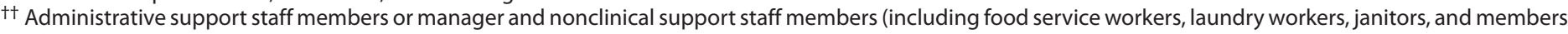
of the housekeeping and maintenance staffs).

$\S \S$ Ambulatory care (physician's office, medical clinic, and other ambulatory care setting).

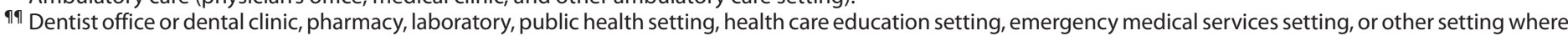
clinical care or related services was provided to patients. 
noted as an increase or decrease when there was at least a 5 percentage point difference between estimates; estimates with smaller differences were considered similar.

Among the 2,012 HCP who started the survey from either source (Medscape or SSI) and had eligible responses to the screening questions, 1,957 (97.3\%) completed the survey. ${ }^{\$ \$}$ Forty-three respondents with completed surveys who reported working in "other health care settings" were excluded because examination of other survey responses indicated that they were either unlikely to have contact with patients or that their work setting was not one of the health care settings of interest for this analysis, leaving a final analytic sample of 1,914 HCP. Overall, 77.3\% of HCP reported receiving an influenza vaccination during the 2014-15 season, an increase of 13.8 percentage points compared with the $2010-11$ season estimate, but similar to the $75.2 \%$ coverage estimate reported in 2013-14 (Figure, Table 1).

With the exception of LTC settings, coverage had increased in all work settings since the 2010-11 season (Figure); however, for all work settings, coverage in the 2014-15 season was similar to coverage in the 2013-14 season (Figure, Table 1). Compared with the 2013-14 season (Table 1), coverage was higher in 2014-15 among pharmacists (95.3\% versus $85.7 \%$ ), assistants/aides (64.4\% versus $57.7 \%)$, and nonclinical personnel $(75.2 \%$ versus $68.6 \%)$. Coverage among other clinical personnel decreased from $87.4 \%$ in $2013-14$ to $81.3 \%$ in 2014-15. Coverage for other occupation types was similar in both seasons.

HCP working in settings with employer vaccination requirements had the highest influenza vaccination coverage (Table 2). During the 2014-15 season, vaccination coverage was $96.0 \%$ among HCP working in settings where vaccination was required. Overall, $40.1 \%$ of surveyed HCP were required to be vaccinated against influenza, an increase from $20.9 \%$ in the 2011-12 season. HCP working in hospitals were most likely to be required to be vaccinated $(64.8 \%)$, with vaccination coverage of $97.2 \%$, and HCP working in LTC settings were least likely to be required to be vaccinated (26.0\%), with vaccination coverage of $97.3 \%$. The lowest vaccination coverage in worksites with employer requirements was $85.7 \%$ among HCP in other clinical settings. Among HCP without an employer requirement for vaccination, vaccination coverage among HCP who worked in locations where their employer made vaccination available on-site at no cost for $>1$ day was $83.9 \%$, compared with coverage of $73.6 \%$ among HCP who

\footnotetext{
$\$ \mathbb{S}$ A survey response rate requires specification of the denominator at each stage of sampling. During recruitment of an online opt-in survey sample, such as the Internet panels described in this report, these numbers are not available; therefore, a response rate cannot be calculated. Instead, the survey cooperation rate is provided.
}

\begin{abstract}
Summary
What is already known on this topic?

The Advisory Committee on Immunization Practices recommends annual influenza vaccination for all health care personnel (HCP) to reduce influenza-related morbidity and mortality in health care settings. Estimated overall HCP vaccination coverage was $75.2 \%$ for the $2013-14$ season.

What is added by this report?

Influenza vaccination coverage among HCP during the 2014-15 influenza season, assessed using an opt-in Internet panel survey, was $77.3 \%$, similar to coverage during the 2013-14 season. Vaccination coverage was highest among physicians, pharmacists, nurse practitioners and physician assistants, nurses, and HCP working in hospital settings. Coverage was lowest among assistants/aides and HCP working in long-term care settings. Offering vaccination at the workplace at no cost was associated with higher vaccination coverage.

What are the implications for public health practice?

Worksites using vaccination requirements or, in the absence of requirements, offering at no cost influenza vaccination on-site over multiple days can achieve high HCP vaccination coverage. Including such measures in comprehensive worksite intervention strategies will be important to ensure HCP and patients are protected against influenza.
\end{abstract}

worked in locations where their employer made vaccination available at no cost for 1 day only and 59.5\% among HCP who worked in locations where their employer did not provide influenza vaccination on-site at no cost but actively promoted vaccination through other mechanisms. 99

Vaccination coverage was lowest (44.0\%) among HCP working in locations where employers neither required vaccination, provided vaccination on-site, nor promoted vaccination. HCP working in LTC settings were most likely to report that their employer neither required, provided, nor promoted vaccination (30.0\%), compared with HCP working in other health care settings. In contrast, only $2.6 \%$ of HCP working in hospitals reported that their employer neither required, provided, nor promoted vaccination (Table 2 ).

\section{Discussion}

The overall $\mathrm{HCP}$ influenza vaccination coverage estimate for the $2014-15$ season was $77.3 \%$, similar to the previous influenza season but higher than the 2010-11 through 2012-13 seasons (G). As in previous influenza seasons, higher vaccination coverage among HCP was associated with employer

\footnotetext{
99 Influenza vaccination was promoted among employees through public identification of vaccinated persons, financial incentives, or rewards to individuals or groups of employees, competition between units or care areas, free or subsidized cost of vaccination, personal reminders to be vaccinated, or publicizing of the number or percentage of employees receiving vaccination.
} 
TABLE 2. Percentage of health care personnel* (HCP) who received influenza vaccination, by work setting, workplace vaccine availability, and employer vaccine requirements status — Internet panel surveys. United States, 2011-12 through 2014-15 influenza seasons

\begin{tabular}{|c|c|c|c|c|c|c|c|c|c|c|c|c|}
\hline \multirow[b]{2}{*}{ Characteristic } & \multicolumn{3}{|c|}{ 2011-12 } & \multicolumn{3}{|c|}{ 2012-13 } & \multicolumn{3}{|c|}{ 2013-14 } & \multicolumn{3}{|c|}{ 2014-15 } \\
\hline & No. & $\begin{array}{l}\text { Weighted } \\
\%^{\dagger}\end{array}$ & $\begin{array}{l}\text { Weighted } \% \\
\text { vaccinated }\end{array}$ & No. & $\begin{array}{c}\text { Weighted } \\
\%^{\dagger}\end{array}$ & $\begin{array}{l}\text { Weighted } \% \\
\text { vaccinated }\end{array}$ & No. & $\begin{array}{c}\text { Weighted } \\
\%^{+}\end{array}$ & $\begin{array}{l}\text { Weighted } \% \\
\text { vaccinated }\end{array}$ & No. & $\begin{array}{c}\text { Weighted } \\
\%^{+}\end{array}$ & $\begin{array}{l}\text { Weighted \% } \\
\text { vaccinated }\end{array}$ \\
\hline $\begin{array}{l}\text { Employer vaccination } \\
\text { requirement }^{\S}\end{array}$ & 496 & 20.9 & 93.7 & 549 & 22.4 & 96.5 & 738 & 35.5 & 97.8 & 725 & 40.1 & 96.0 \\
\hline Hospital & 362 & 32.0 & 95.2 & 388 & 37.1 & 95.1 & 520 & 58.2 & 97.7 & 440 & 64.8 & 97.2 \\
\hline $\begin{array}{l}\text { Ambulatory care/ } \\
\text { Physician office }\end{array}$ & 153 & 21.8 & 95.5 & 191 & 20.9 & 99.8 & 252 & 33.6 & 96.4 & 277 & 34.7 & 96.1 \\
\hline Long-term care & 45 & 10.1 & 86.1 & 61 & 12.8 & 95.8 & 88 & 20.1 & 98.4 & 104 & 26.0 & 97.3 \\
\hline Other clinical setting ${ }^{* *}$ & 21 & 7.1 & ${ }_{-}^{\dagger+}$ & 38 & 10.7 & 100 & 88 & 29.3 & 99.5 & 109 & 35.9 & 85.7 \\
\hline $\begin{array}{l}\text { On-site vaccination } \\
>1 \text { day§§ }\end{array}$ & 971 & 34.4 & 71.6 & 658 & 28.5 & 80.5 & 542 & 25.1 & 80.4 & 407 & 19.1 & 83.9 \\
\hline Hospital & 598 & 47.0 & 72.3 & 382 & 37.3 & 81.9 & 261 & 31.4 & 82.0 & 151 & 21.0 & 86.9 \\
\hline $\begin{array}{l}\text { Ambulatory care/ } \\
\text { Physician office }\end{array}$ & 314 & 32.4 & 70.0 & 189 & 27.8 & 82.3 & 183 & 28.6 & 80.7 & 165 & 23.1 & 87.8 \\
\hline Long-term care & 124 & 19.7 & 61.2 & 115 & 17.3 & 74.8 & 63 & 11.7 & 71.6 & 57 & 12.4 & 67.3 \\
\hline Other clinical setting ${ }^{* *}$ & 88 & 27.8 & 87.1 & 85 & 28.6 & 84.3 & 107 & 22.0 & 85.0 & 97 & 15.6 & 81.9 \\
\hline $\begin{array}{l}\text { On-site vaccination } \\
1 \text { day }\end{array}$ & 245 & 11.7 & 59.9 & 227 & 9.8 & 67.6 & 169 & 7.6 & 61.6 & 230 & 9.8 & 73.6 \\
\hline Hospital & 104 & 10.0 & 60.1 & 89 & 9.9 & 66.3 & 43 & 4.2 & 55.6 & 51 & 7.3 & 72.1 \\
\hline $\begin{array}{l}\text { Ambulatory care/ } \\
\text { Physician office }\end{array}$ & 82 & 12.3 & 52.8 & 88 & 9.3 & 80.1 & 76 & 11.3 & 69.3 & 104 & 10.9 & 80.6 \\
\hline Long-term care & 48 & 12.9 & 53.2 & 58 & 11.3 & 49.7 & 43 & 10.0 & 54.1 & 45 & 10.0 & 67.1 \\
\hline Other clinical setting ${ }^{* *}$ & 40 & 12.5 & 89.7 & 25 & 7.3 & - $^{\dagger+}$ & 31 & 6.5 & 72.9 & 50 & 10.8 & 80.4 \\
\hline $\begin{array}{l}\text { Other vaccination } \\
\text { promotion }\end{array}$ & 231 & 12.2 & 58.4 & 250 & 17.4 & 69.2 & 226 & 15.5 & 61.9 & 216 & 12.4 & 59.5 \\
\hline Hospital & 60 & 6.4 & 56.3 & 77 & 13.4 & 73.4 & 46 & 5.1 & 80.7 & 24 & 4.4 & - \\
\hline $\begin{array}{c}\text { Ambulatory care/ } \\
\text { Physician office }\end{array}$ & 72 & 11.6 & 63.8 & 65 & 13.1 & 76.8 & 66 & 12.2 & 53.5 & 67 & 10.3 & 60.5 \\
\hline Long-term care & 80 & 20.3 & 55.9 & 83 & 23.6 & 63.2 & 90 & 29.8 & 62.2 & 83 & 21.6 & 58.5 \\
\hline Other clinical setting ${ }^{* *}$ & 42 & 18.8 & 54.0 & 55 & 28.8 & 71.0 & 50 & 16.9 & 57.5 & 54 & 14.6 & 64.5 \\
\hline $\begin{array}{l}\text { No requirement, } \\
\text { on-site vaccination } \\
\text { or promotion }\end{array}$ & 405 & 20.7 & 40.0 & 260 & 21.9 & 40.4 & 207 & 16.3 & 36.8 & 336 & 18.7 & 44.0 \\
\hline Hospital & 63 & 4.6 & 62.5 & 25 & 2.3 & - & 10 & 1.2 & - & 15 & 2.6 & - \\
\hline $\begin{array}{l}\text { Ambulatory care/ } \\
\text { Physician office }\end{array}$ & 126 & 22.0 & 46.2 & 103 & 28.9 & 40.2 & 72 & 14.3 & 26.8 & 133 & 21.0 & 46.6 \\
\hline Long-term care & 158 & 37.0 & 35.1 & 110 & 35.0 & 37.5 & 80 & 28.5 & 38.6 & 117 & 30.0 & 36.4 \\
\hline Other clinical setting & 86 & 33.9 & 30.7 & 34 & 24.6 & 48.7 & 51 & 25.3 & 36.9 & 79 & 23.2 & 53.4 \\
\hline
\end{tabular}

* Persons who worked in a place where clinical care or related services were provided to patients, or whose work involved face-to-face contact with patients or who were ever in the same room as patients.

† Weights were calculated based on each occupation type, by age, sex, race/ethnicity, work setting, and U.S. Census region to represent the U.S. population of HCP. Work setting and overall occupation are presented as weighted estimates of the total sample. Where the groups are stratified by work setting, the estimates are presented as weighted estimates of the occupation group subsample of each work setting subgroup.

$\S$ Includes all respondents who indicated that their employer required them to be vaccinated for influenza.

I Ambulatory care (physician's office, medical clinic, and other ambulatory care setting).

** Dentist office or dental clinic, pharmacy, laboratory, public health setting, health care education setting, emergency medical services setting, or other setting where clinical care or related services was provided to patients.

${ }^{+\dagger}$ Vaccination coverage estimate not reliable because the sample size was $<30$

$\S \S$ Employer made influenza vaccination available on-site for $>1$ day during the influenza season at no cost to employees. Restricted to respondents without an employer requirement for vaccination.

१ๆ Employer made influenza vaccination available on-site for 1 day during the influenza season at no cost to employees. Restricted to respondents without an employer requirement for vaccination.

*** Influenza vaccination was promoted among employees through public identification of vaccinated persons, financial incentives, or rewards to individuals or groups of employees, competition between units or care areas, free or subsidized cost of vaccination, personal reminders to be vaccinated, or publicizing of the number or percentage of employees receiving vaccination.

vaccination requirements or access to vaccination at the workplace at no cost for more than 1 day $(6)$. Access to influenza vaccination at the worksite has been associated with higher vaccination coverage among HCP in previous studies $(6,8)$. These findings support recommendations for a comprehensive strategy that includes easy access to vaccination at no cost on multiple days, along with promotion of vaccination, to increase HCP influenza vaccination coverage $(1,7)$.

Coverage among HCP working in LTC settings was the lowest among the work settings examined, a finding that was consistent with the previous three seasons (G). Influenza vaccination among HCP in LTC settings is important because 
influenza vaccine effectiveness is generally lowest in the elderly, making vaccination of close contacts even more critical (3). In addition, multiple studies have demonstrated that vaccination of HCP in LTC settings confers a health benefit to patients, including reduced risk for mortality (2-4). HCP working in LTC settings were least likely to report that their employer required vaccination or made vaccination available on-site at no cost for multiple days. Implementing strategies shown to improve HCP workplace vaccination coverage, including vaccination requirements or offering at no cost on-site vaccinations over multiple days, can help protect LTC patients from influenza $(7)$.

HCP working in hospitals had the highest vaccination coverage and were the most likely to report that their employer required vaccination. Higher vaccination coverage and increased use of vaccination requirements and promotion in hospitals compared with other settings might be partly attributable to the Centers for Medicare and Medicaid Services (CMS) requirement in place since January 2013 to report HCP influenza vaccination levels as part of its hospital quality reporting programs (9). CMS has since added HCP influenza vaccination to quality reporting programs for other HCP work settings, which might affect vaccination coverage in nonhospital settings in future years; however, not all work settings are included in the program.

The findings in this report are subject to at least three limitations, all of which have been described previously (G). First, the sample was not randomly selected from HCP in the United States. The survey used a nonprobability sample of volunteer HCP members of Medscape and SSI Internet panels and the results based on this nonprobability sample might not be representative of the HCP population in the United States, in particular, those without internet access. Second, influenza vaccination coverage among HCP from the opt-in Internet panel survey $(72.0 \%)$ differed from the population-based sample in the National Health Interview Survey in the 2009-10 through 2012-13 influenza seasons (66.9\% for the $2012-13$ season), although trends in coverage were similar across seasons (10) (CDC, unpublished data, 2015). Finally, all results were based on self-report and might be subject to recall bias.

The highest HCP vaccination coverage was reported in worksites with employer requirements for vaccination. In the absence of vaccination requirements, expanding the number of health care locations offering vaccination on-site, over multiple days, and at no cost might help sustain and improve influenza vaccination coverage among HCP. Employers and health care administrators can make use of the Guide to Community Preventive Services, which has found evidence to support onsite vaccination at no or low cost to HCP to increase influenza vaccination coverage among $\mathrm{HCP}(7)$. LTC employers can also use the LTC web-based toolkit*** developed by CDC and the National Vaccine Program Office, which provides access to resources, strategies, and educational materials for increasing influenza vaccination among HCP in LTC settings.

\footnotetext{
*** The long-term care web-based toolkit is available at http://www.cdc.gov/ flu/toolkit/long-term-care/index.htm.
}

\begin{abstract}
${ }^{1}$ Immunization Services Division, National Center for Immunization and Respiratory Diseases, CDC; ${ }^{2} \mathrm{Abt}$ Associates Inc., Cambridge, MA; ${ }^{3}$ Division of Surveillance, Hazard Evaluations, and Field Studies, National Institute for Occupational Safety and Health, CDC; ${ }^{4}$ Division of Respiratory Disease Studies, National Institute for Occupational Safety and Health, CDC; ${ }^{5} \mathrm{Abt}$ SRBI, New York, NY.
\end{abstract}

(Corresponding author: Carla L. Black, cblack2@cdc.gov, 404-639-8436).

\section{References}

1. CDC. Immunization of health-care personnel: recommendations of the Advisory Committee on Immunization Practices (ACIP). MMWR Recomm Rep 2011;60(No. RR-7).

2. Carman WF, Elder AG, Wallace LA, et al. Effects of influenza vaccination of health-care workers on mortality of elderly people in long-term care: a randomised controlled trial. Lancet 2000;355:93-7.

3. Hayward AC, Harling R, Wetten S, et al. Effectiveness of an influenza vaccine programme for care home staff to prevent death, morbidity, and health service use among residents: cluster randomised controlled trial. BMJ 2006;333:1241.

4. Lemaitre M, Meret T, Rothan-Tondeur M, et al. Effect of influenza vaccination of nursing home staff on mortality of residents: a clusterrandomized trial. J Am Geriatr Soc 2009;57:1580-6.

5. Saxén H, Virtanen M. Randomized, placebo-controlled double blind study on the efficacy of influenza immunization on absenteeism of health care workers. Pediatr Infect Dis J 1999;18:779-83.

6. Black CL, Yue X, Ball SW, et al. Influenza vaccination coverage among health care personnel-United States, 2013-14 influenza season. MMWR Morb Mortal Wkly Rep 2014;63:805-11.

7. Community Preventive Services Task Force. Interventions to promote seasonal influenza vaccinations among healthcare workers. Atlanta, GA: The Guide to Community Preventive Services; 2008. Available at http:// www.thecommunityguide.org/worksite/flu-how.html.

8. Hollmeyer H, Hayden F, Mounts A, Buchholz U. Review: interventions to increase influenza vaccination among healthcare workers in hospitals. Influenza Other Respir Viruses 2013;7:604-21.

9. Lindley MC, Bridges CB, Strikas RA, et al. Influenza vaccination performance measurement among acute care hospital-based health care personnel-United States, 2013-14 influenza season. MMWR Morb Mortal Wkly Rep 2014;63:812-5.

10. CDC. Surveillance of influenza vaccination coverage-United States, 2007-08 through 2011-12 influenza seasons. MMWR Surveill Summ 2013;62(No. SS-04). 


\title{
Influenza Vaccination Coverage Among Pregnant Women - United States, 2014-15 Influenza Season
}

\begin{abstract}
Helen Ding, MD ${ }^{1}$; Carla L. Black, $\mathrm{PhD}^{2}$; Sarah Ball, $\mathrm{ScD}^{3}$; Sara Donahue, DrPH³; Rebecca V. Fink, MPH ${ }^{3}$; Walter W. Williams, MD²; Erin D. Kennedy, DVM²; Carolyn B. Bridges, MD²; Peng-Jun Lu, MD, PhD²; Katherine E. Kahn, MPH4; Anna K Dean, MPH ${ }^{2,5}$; Lisa A. Grohskopf, $\mathrm{MD}^{6}$; Indu B. Ahluwalia, $\mathrm{PhD}^{7}$; Rebecca Devlin, $\mathrm{MA}^{8}$; Charles DiSogra, DrPH${ }^{8}$; Deborah K. Walker, EdD ${ }^{3}$; Stacie M. Greby, DVM ${ }^{2}$
\end{abstract}

Pregnant women and infants are at increased risk for influenza-related complications and hospitalization. Influenza vaccination can reduce the risk for influenza-related illness among pregnant women and their infants (1). Since 2004, the Advisory Committee on Immunization Practices (ACIP) and the American College of Obstetricians and Gynecologists (ACOG) have recommended influenza vaccination for all women who are or will be pregnant during the influenza season, regardless of trimester of pregnancy $(1,2)$. To assess influenza vaccination coverage among pregnant women during the 2014-15 influenza season, CDC analyzed data from an Internet panel survey conducted during March 31-April 6, 2015. Among 1,702 survey respondents who were pregnant at any time during October 2014-January 2015, 50.3\% reported receiving influenza vaccination before or during pregnancy, similar to the reported coverage in the preceding season (3). Overall, $64.9 \%$ of respondents reported receiving a provider offer of influenza vaccination, $14.8 \%$ received a recommendation but no offer, and $20.3 \%$ received no recommendation. Vaccination coverage among these groups of women was $67.9 \%, 33.5 \%$, and $8.5 \%$, respectively. Reminder systems and standing orders that allow health care personnel other than the attending provider to assess vaccination status and administer vaccination, can help to ensure that influenza vaccination is recommended and offered to a pregnant woman at each provider visit to increase pregnant women's vaccination coverage $(4,5)$.

Since the 2010-11 influenza season, CDC has conducted an Internet panel survey annually each April to provide end-ofseason influenza vaccination coverage estimates among pregnant women. For the 2014-15 influenza season, the Internet panel survey was conducted during March 31-April 6, 2015 for CDC by Abt Associates, Inc., to 1) provide end-of-season estimates of influenza vaccination coverage among pregnant women; 2) assess respondent-reported provider recommendation for and offer of influenza vaccination; and 3) obtain updated information on pregnant women's knowledge, attitudes, and behaviors related to influenza vaccination. Women aged 18-49 years who reported being pregnant at any time since August 2014 were eligible to participate in the survey. Participants were recruited from a preexisting, national, opt-in, general population Internet panel operated by Survey Sampling
International, which provides panel members with online survey opportunities in exchange for nominal incentives.* Pregnant women panelists were recruited through 1) an email invitation sent to female panel members aged 18-49 years living in the United States, and 2) a message on the panel website inviting panel members to answer a series of screening questions and, if eligible, to take the survey. Among 12,533 women who entered the survey site during March 31-April 6, 2015, 2,171 were determined to be eligible, and 2,053 completed the survey (completion rate ${ }^{\dagger}=94.6 \%$ ). Data were weighted to reflect the age, race/ethnicity, and geographic distribution of the total U.S. population of pregnant women. A woman was considered to be vaccinated if 1 ) vaccination was received during July 1, 2014-April 6, 2015 and 2) vaccination was received before or during the most recent pregnancy. The study population was limited to 1,702 women who reported being pregnant any time during the peak influenza vaccination period (October 2014-January 2015). Vaccination coverage estimates for the preceding five seasons were compared to assess trends over time. Similar survey methodology was used in all five seasons (3).

Survey respondents were asked about their vaccination status (before and/or during pregnancy), whether their provider recommended or offered influenza vaccination, their attitudes regarding influenza and influenza vaccination, and their reasons for receiving or not receiving influenza vaccination. Three composite variables defining attitudes about influenza vaccination efficacy, safety, and concerns about influenza infection were constructed using methods previously described (3). Because the opt-in Internet panel sample is not probability-based, no statistical tests were performed. ${ }^{\S}$ Differences were noted when there was a $\geq 5$ percentage-point difference between any values being compared.

\footnotetext{
*Additional information on the online survey and incentives for participants is available at https://www.surveysampling.com.

$\dagger$ An opt-in Internet panel survey is a nonprobability sampling survey. The denominator for a response rate calculation cannot be determined because no sampling frame with a selection probability is involved at the recruitment stage. Instead, the survey completion rate is provided. Completion rate is the percentage of women who completed the survey, among those that were eligible and started the survey.

$\S$ Additional information on obstacles to inference in non-probability samples is available at http://www.aapor.org/AAPORKentico/default.aspx.
} 
Among the 1,702 women who were pregnant at any time during October 2014-January 2015, 50.3\% reported receiving influenza vaccination before pregnancy $(15.3 \%)$ or during pregnancy $(35.0 \%)$ since July 1, 2014. The overall vaccination coverage was similar to that in the 2013-14 (52.2\%) influenza season (Table 1). Non-Hispanic black women reported lower vaccination coverage $(38.9 \%)$ than did non-Hispanic white women $(51.9 \%)$. Compared with women in the reference category for each comparison stratum, lower influenza vaccination coverage was reported among women who were aged $<35$ years, had a college degree or less, were not married, had public insurance or no medical insurance, were not working for wages, were living below the poverty threshold, reported no high-risk conditions associated with increased influenza risk other than pregnancy, reported fewer than six visits to a health care provider since July 2014 , and had a negative attitude toward efficacy or safety of influenza vaccination or were not concerned about influenza infection (Table 1).

Among women with at least one visit to a health care provider since July 2014, women who reported that a provider both recommended and offered influenza vaccination had higher vaccination coverage $(67.9 \%)$ compared with women who reported receiving a provider recommendation but no offer $(33.5 \%)$ and women who reported receiving no recommendation for vaccination (8.5\%) (Figure). Compared with women in the reference category for each comparison stratum, a recommendation for and offer of influenza vaccination was less frequently reported by women who were aged $<35$ years,

TABLE 1. Influenza vaccination coverage before and during pregnancy among women who were pregnant any time during October 2014January 2015, by selected characteristics - Internet panel surveys, United States, 2014-15 and 2013-2014 influenza seasons

\begin{tabular}{|c|c|c|c|c|c|c|c|}
\hline \multirow[b]{2}{*}{ Characteristic } & \multicolumn{3}{|c|}{ 2013-14 influenza season } & \multicolumn{3}{|c|}{ 2014-15 influenza season } & \multirow{2}{*}{$\begin{array}{c}\text { Percentage point } \\
\text { difference in } \\
\text { vaccination coverage } \\
(2014-15-2013-14)\end{array}$} \\
\hline & Unweighted no. & Weighted \% & $\begin{array}{c}\text { Vaccinated, } \\
\text { weighted } \\
\%\end{array}$ & Unweighted no. & Weighted \% & $\begin{array}{c}\text { Vaccinated, } \\
\text { weighted } \\
\%\end{array}$ & \\
\hline Total & 1,619 & & 52.2 & 1,702 & & 50.3 & -1.9 \\
\hline Vaccinated before pregnancy & 289 & & 17.6 & 265 & & 15.3 & -2.3 \\
\hline Vaccinated during pregnancy & 577 & & 34.6 & 615 & & 35.0 & 0.4 \\
\hline \multicolumn{8}{|l|}{ Age (yrs) } \\
\hline $18-24$ & 373 & 34.0 & $45.6^{*}$ & 436 & 30.5 & $44.1^{*}$ & -1.5 \\
\hline $25-34$ & 942 & 50.4 & 56.5 & 920 & 52.5 & $50.0^{*}$ & $-6.5^{\dagger}$ \\
\hline $35-49^{\S}$ & 304 & 15.6 & 53.0 & 346 & 17.0 & 61.9 & $8.9^{\dagger}$ \\
\hline \multicolumn{8}{|l|}{ Race/Ethnicity } \\
\hline Hispanic & 260 & 23.7 & 56.7 & 425 & 22.3 & 56.5 & -0.2 \\
\hline Black, non-Hispanic & 160 & 18.1 & $42.7^{*}$ & 241 & 19.1 & $38.9^{*}$ & -3.7 \\
\hline White, non-Hispanic $§$ & 1,033 & 50.1 & 52.0 & 887 & 49.9 & 51.9 & -0.1 \\
\hline Other, non-Hispanic & 166 & 8.1 & $61.9^{*}$ & 149 & 8.6 & 49.8 & $-12.1^{\dagger}$ \\
\hline \multicolumn{8}{|l|}{ Education } \\
\hline$<$ College degree & 699 & 47.7 & $44.6^{*}$ & 819 & 50.2 & $42.0^{*}$ & -2.6 \\
\hline College degree & 714 & 41.1 & $57.4^{*}$ & 666 & 37.7 & $56.6^{*}$ & -0.8 \\
\hline$>$ College degree ${ }^{\S}$ & 206 & 11.2 & 65.9 & 217 & 12.1 & 64.7 & -1.2 \\
\hline \multicolumn{8}{|l|}{ Married } \\
\hline Yes $^{\S}$ & 1,128 & 63.4 & $56.6^{*}$ & 1,110 & 62.3 & 54.5 & -2.1 \\
\hline No & 491 & 36.6 & 44.7 & 592 & 37.7 & $43.3^{*}$ & -1.5 \\
\hline \multicolumn{8}{|l|}{ Insurance coverage } \\
\hline Private/Military only ${ }^{\S}$ & 993 & 56.6 & 54.9 & 940 & 53.7 & 54.6 & -0.3 \\
\hline Any public & 579 & 40.0 & 51.0 & 704 & 42.7 & $46.8^{*}$ & -4.2 \\
\hline No insurance & 47 & 3.3 & $22.2^{*}$ & 58 & 3.6 & $27.5^{*}$ & $5.3^{\dagger}$ \\
\hline \multicolumn{8}{|l|}{ Working status? } \\
\hline Yes $^{\S}$ & 855 & 50.8 & 57.3 & 942 & 53.8 & 56.5 & -0.8 \\
\hline No & 764 & 49.2 & $47.0^{*}$ & 760 & 46.2 & $43.1^{*}$ & -3.9 \\
\hline \multicolumn{8}{|l|}{ Poverty status** } \\
\hline At or above ${ }^{\S}$ & 1,369 & 81.5 & 53.9 & 1,337 & 76.7 & 54.3 & 0.4 \\
\hline Below & 250 & 18.5 & $45.0^{*}$ & 362 & 23.3 & $37.4^{*}$ & $-7.6^{\dagger}$ \\
\hline \multicolumn{8}{|l|}{ High-risk conditions ${ }^{\dagger \dagger}$} \\
\hline Yes $^{\S}$ & 538 & 33.0 & $60.5^{*}$ & 658 & 38.3 & 56.4 & -4.1 \\
\hline No & 1,081 & 67.0 & 48.2 & 1,044 & 61.7 & $46.5^{*}$ & -1.7 \\
\hline \multicolumn{8}{|c|}{ No. of visits to a provider since July } \\
\hline None & 16 & 0.9 & —§§ & 18 & 1.1 & —§§ & —§§ \\
\hline $1-5$ & 370 & 23.2 & $42.7^{*}$ & 399 & 23.7 & $37.4^{*}$ & $-5.3^{\dagger}$ \\
\hline $6-10$ & 652 & 40.4 & 55.0 & 657 & 38.1 & 55.1 & 0.1 \\
\hline$>10^{\S}$ & 581 & 35.5 & 56.5 & 628 & 37.1 & 54.8 & -1.7 \\
\hline
\end{tabular}

See table footnotes on the next page. 
had less than a college degree, were unmarried, did not have medical insurance, were not working for wages, were living below the poverty threshold, did not have high-risk conditions, had fewer than 10 visits to a provider, and had a negative attitude toward influenza vaccination efficacy or safety or were not concerned about influenza infection (Table 2). Similarly, across all subgroups, influenza vaccination coverage was highest among women whose provider recommended and offered vaccination, followed by women who received only a recommendation but no offer, and lowest among women who received no provider recommendation. Even among women who reported negative attitudes regarding influenza vaccine efficacy or safety, or were not concerned about influenza infection, coverage was higher among those whose provider recommended and offered vaccination than among women with the same beliefs who reported only receiving a provider recommendation or receiving no recommendation (Table 2). Among vaccinated women, $86.8 \%$ reported that their provider recommended and offered vaccination; among unvaccinated women, the percentage was only $42.3 \%$.

The most common reasons women reported for receiving influenza vaccination were "to protect my baby from flu" (33.1\%), "to protect myself from flu" (21.4\%), and "my doctor, nurse, or other medical professional recommended the flu vaccination" (15.0\%). The most common reasons women reported for not receiving vaccination were "I don't think the vaccination is effective in preventing flu" (17.2\%), "I have concerns about possible safety risk to my baby if I got vaccinated" (14.5\%) and "I am concerned that the vaccination would give me the flu" (13.6\%).

\section{Discussion}

During the 2014-15 influenza season approximately half of surveyed pregnant women had received influenza vaccination, similar to the percentages found for the 2013-14 (52.2\%), 2012-13 (50.5\%), and 2011-12 (46.4\%) influenza seasons,

TABLE 1. (Continued) Influenza vaccination coverage before and during pregnancy among women who were pregnant any time during October 2014-January 2015, by selected characteristics — Internet panel surveys, United States, 2014-15 and 2013-2014 influenza seasons

\begin{tabular}{|c|c|c|c|c|c|c|c|}
\hline \multirow[b]{2}{*}{ Characteristic } & \multicolumn{3}{|c|}{ 2013-14 influenza season } & \multicolumn{3}{|c|}{ 2014-15 influenza season } & \multirow{2}{*}{$\begin{array}{l}\text { Percentage point } \\
\text { difference in } \\
\text { vaccination coverage } \\
(2014-15-2013-14)\end{array}$} \\
\hline & Unweighted no. & Weighted \% & $\begin{array}{c}\text { Vaccinated, } \\
\text { weighted } \\
\%\end{array}$ & Unweighted no. & Weighted \% & $\begin{array}{c}\text { Vaccinated, } \\
\text { weighted } \\
\%\end{array}$ & \\
\hline \multicolumn{8}{|c|}{ Provider recommendation and/or offer of influenza vaccination ${ }^{\text {ๆศ }}$} \\
\hline Recommended, offered & 1,037 & 65.1 & $70.5^{*}$ & 1,107 & 64.9 & $67.9^{*}$ & -2.6 \\
\hline Recommended, no offer & 242 & 15.1 & $32.0^{*}$ & 246 & 14.8 & $33.5^{*}$ & 1.5 \\
\hline No recommendation ${ }^{\S}$ & 324 & 19.8 & 9.7 & 331 & 20.3 & 8.5 & -1.2 \\
\hline \multicolumn{8}{|c|}{ Attitude toward efficacy of influenza vaccination $* * *$} \\
\hline Positive ${ }^{\S}$ & 1,316 & 81.3 & 62.9 & 1,302 & 75.8 & 62.4 & -0.5 \\
\hline Negative & 303 & 18.7 & $5.8^{*}$ & 400 & 24.2 & $12.2^{*}$ & $6.4^{\dagger}$ \\
\hline \multicolumn{8}{|c|}{ Attitude toward safety of influenza vaccination ${ }^{\dagger+\dagger}$} \\
\hline Positive $§$ & 1,241 & 75.2 & 65.1 & 1,278 & 74.0 & 63.5 & -1.7 \\
\hline Negative & 378 & 24.8 & $13.2^{*}$ & 424 & 26.0 & $12.6^{*}$ & -0.6 \\
\hline \multicolumn{8}{|c|}{ Attitude toward influenza infection ${ }^{\S \S}$} \\
\hline Concerned ${ }^{\S}$ & 1,127 & 69.8 & 58.0 & 1,145 & 67.3 & 56.0 & -2.0 \\
\hline Not concerned & 492 & 30.2 & $39.0^{*}$ & 557 & 32.7 & $38.4^{*}$ & -0.6 \\
\hline
\end{tabular}

$* \geq 5$ percentage point difference compared with reference group.

${ }^{\dagger} \geq 5$ percentage point difference from 2013-14 to 2014-15 influenza season.

$\S$ Reference group for comparisons within subgroups.

" Working status: Yes = those employed for wages and self-employed; No = those out of work, homemakers, students, retired, or unable to work

** As determined by the U.S. Census Bureau (http://www.census.gov/hhes/www/poverty/data/threshld), for the 2014-15 season below poverty = total family income of $<\$ 24,008$ for a family of four with two minors as of 2014 ; for the 2013-14 season below poverty = total annual family income of $<\$ 23,624$ for a family of four with two minors as of 2013.

${ }^{+\dagger}$ Conditions associated with increased risk for serious medical complications from influenza, including chronic asthma, a lung condition other than asthma, a heart condition, diabetes, a kidney condition, a liver condition, obesity, or a weakened immune system caused by a chronic illness or by medicines taken for a chronic illness.

$\S \S$ Vaccination coverage estimate was not reliable because sample size was $<30$.

१ๆ Excluding women who had not visited a health care provider since July $2013(n=16)$ for the 2013-14 influenza season, and who had not visited a health care provider since July $2014(n=18)$ for the 2014-15 influenza season.

*** Created based on two questions regarding attitudes toward the efficacy of flu vaccination: 1) "Flu vaccine is somewhat/very effective in preventing flu," and 2) "Flu vaccine a pregnant women received is somewhat/very effective in protecting her baby from the flu." A 1-point score was given for each "yes" answer for either of the two questions. "Positive" attitude = summary score of 1 or $2 ;$ "Negative" attitude = summary score of 0 .

${ }^{+t+}$ Created based on three questions regarding attitudes toward the safety of flu vaccination: 1)"Flu vaccination is somewhat/very/completely safe for most adult women"; 2) "Flu vaccination is somewhat/very/completely safe for pregnant women"; and 3) "Flu vaccination that a pregnant woman receives is somewhat/very/ completely safe for her baby." 1 point was given for each "yes" answer for any of the 3 questions. "Positive" attitude = summary score of 2 or 3 ; "Negative" attitude $=$ summary score of 0 or 1 .

$\S \S \S$ Created based on three questions regarding attitude toward flu infection: 1) "If a pregnant woman gets the flu, it is somewhat/very likely to harm the baby"; 2 ) "Flu infection during pregnancy somewhat/very likely harms pregnant women"; and 3) "somewhat/very worried about getting sick with the flu this season ." 1 point was given for each "yes" answer for any of the 3 questions. "Concerned" = summary score of 2 or 3; "Not concerned" = summary score of 1 or 0. 
FIGURE. Percentage of women vaccinated for influenza before and during pregnancy, overall and by health care provider recommendation and offer* of influenza vaccination, among women pregnant at any time during October 2014-January 2015 - Internet panel survey, United States, 2014-15 influenza season

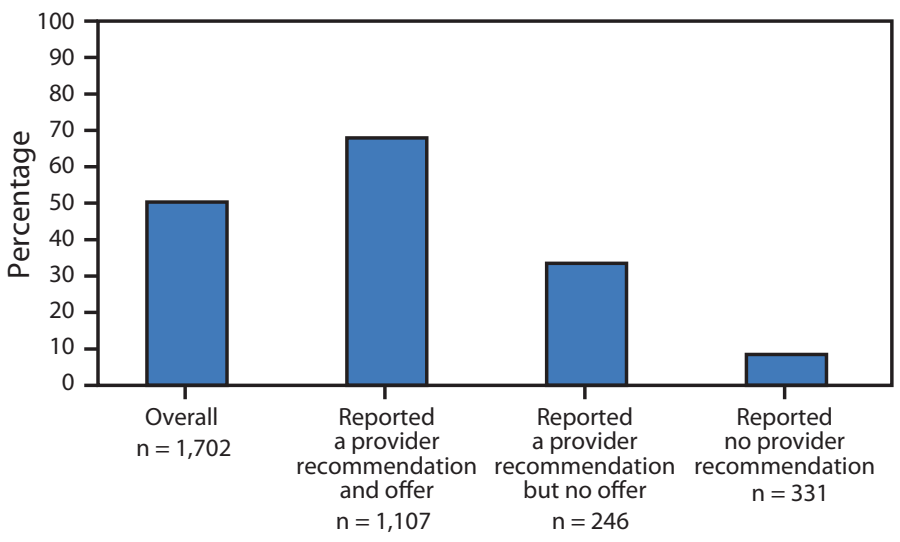

* Excluded women who had not visited a health care provider since July 2014 $(n=18)$.

but higher than those found for the 2010-11 season (44.0\%) (3). A substantially higher percentage of women who reported that their provider both recommended and offered influenza vaccination had received influenza vaccine compared with women who reported receiving only a recommendation but no offer or no recommendation; however, the percentage of women receiving a provider offer and recommendation was similar to last season.

The higher coverage reported among pregnant women whose provider recommended and offered influenza vaccination, including women with negative attitudes about influenza vaccine efficacy or safety, or who were not concerned about getting influenza, highlights the importance of a provider recommendation for influenza vaccination coupled with an offer of influenza vaccination onsite to increase vaccination coverage among pregnant women. Implementing and strengthening systems that support provider ability to recommend and offer influenza vaccination to pregnant women, including standing orders and provider reminder systems, as well as expanded access to vaccination services in expanded health care settings, such as pharmacies, can increase opportunities for vaccination and improve coverage $(4,5)$.

Similar to previous seasons, vaccination coverage was lower among black women than white women, despite a similar percentage of black and white women reporting receiving a provider recommendation and offer of vaccination, highlighting the need to identify and address possible factors contributing to this disparity, which might include weaker or less effective provider recommendations, differences in sociocultural norms, misperception of vaccine effectiveness and safety, vaccination resistance and hesitancy, and poorer quality of provider-patient relationships $(6,7)$.

\section{Summary \\ What is already known on this topic?}

Pregnant women and infants are at increased risk for influenzarelated complications. The risk of influenza among pregnant women and their infants aged $<6$ months can be reduced by vaccinating pregnant women. Influenza vaccination coverage among pregnant women increased substantially during the 2009-10 influenza season and the increased coverage was sustained during the 2010-11 through 2013-14 seasons.

What is added by this report?

During the 2014-15 influenza season, 50.3\% of pregnant women were vaccinated before or during pregnancy, similar to the 2013-14 season. Women who received a provider offer of vaccination had substantially higher vaccination coverage than those who did not receive an offer of vaccination. Barriers to vaccination included negative attitudes about safety and efficacy of influenza vaccination and unfounded concern that vaccination would cause influenza.

What are the implications for public health practice?

To protect mothers and their babies from complications of influenza, efforts are needed to improve influenza vaccination coverage among pregnant women. Interventions should include implementing clinic-based education to ensure access to information about influenza vaccine safety and efficacy and the risk for influenza for pregnant women and their infants, and systems to ensure that providers recommend and offer influenza vaccination to all pregnant women.

Unlike the previous influenza seasons, during the 2014-15 season the most commonly reported reason for not being vaccinated concerned lack of confidence in influenza vaccine efficacy, which might have reflected knowledge about the mismatch of the influenza vaccine with the circulating strain in the 2014-15 season $(3,8)$. In addition to addressing this concern, clinic-based client education for pregnant women should emphasize that influenza vaccination during pregnancy is safe and can protect not only pregnant women themselves but also their infants during the first 6 months of life when they are too young to receive vaccination $(1,2,4)$. This education needs to be supported by provider recommendation for and offer of influenza vaccination during the visit (4). Education messages can be delivered through multiple channels, including prenatal care consultation, social media, and text messaging (e.g., applications such as https://text4baby.org).

The findings in this report are subject to at least four limitations. First, vaccination was self-reported and not validated by medical records; therefore, coverage might be over- or underestimated. Second, the study sample did not include women without Internet access. Therefore, results are not generalizable to all pregnant women in the United States. Third, the Internet panel survey is an opt-in survey and estimates might be biased 
TABLE 2. Percentage of women receiving a provider recommendation/offer of influenza vaccination and influenza vaccination coverage, by provider recommendation and offer of influenza vaccination, among women who visited a provider at least one time since July 2014 and who were pregnant any time during October 2014-January 2015 - Internet panel survey, United States, 2014-15 influenza season

\begin{tabular}{|c|c|c|c|c|c|c|c|c|c|c|}
\hline \multirow[b]{3}{*}{ Characteristic } & \multirow{3}{*}{$\begin{array}{c}\text { Unweighted } \\
\text { no. }\end{array}$} & \multicolumn{3}{|c|}{$\begin{array}{l}\text { Provider recommendation/offer of influenza } \\
\text { vaccination }\end{array}$} & \multicolumn{6}{|c|}{ Vaccination coverage } \\
\hline & & \multirow{2}{*}{$\begin{array}{c}\text { Recommended } \\
\text { offered, } \\
\text { weighted } \\
\%\end{array}$} & \multirow{2}{*}{$\begin{array}{l}\text { Recommended, } \\
\text { no offer, } \\
\text { weighted } \\
\%\end{array}$} & \multirow{2}{*}{$\begin{array}{c}\text { No } \\
\text { recommendation, } \\
\text { weighted } \\
\%\end{array}$} & \multicolumn{2}{|c|}{$\begin{array}{c}\text { Provider } \\
\text { recommended, } \\
\text { offered }\end{array}$} & \multicolumn{2}{|c|}{$\begin{array}{l}\text { Provider } \\
\text { recommended, } \\
\text { no offer }\end{array}$} & \multicolumn{2}{|c|}{ No recommendation } \\
\hline & & & & & $\begin{array}{l}\text { Unweighted } \\
\text { no. }\end{array}$ & $\begin{array}{l}\text { Weighted } \\
\%\end{array}$ & $\begin{array}{l}\text { Unweighted } \\
\text { no. }\end{array}$ & $\begin{array}{l}\text { Weighted } \\
\%\end{array}$ & $\begin{array}{l}\text { Unweighted } \\
\text { no. }\end{array}$ & $\begin{array}{l}\text { Weighted } \\
\%\end{array}$ \\
\hline Total & 1,684 & 64.9 & 14.8 & 20.3 & 1,107 & 67.9 & 246 & 33.5 & 331 & 8.5 \\
\hline $\begin{array}{l}\text { Age (years) } \\
18-24 \\
25-34 \\
35-49^{\dagger}\end{array}$ & $\begin{array}{l}429 \\
911 \\
344\end{array}$ & $\begin{array}{l}57.6^{*} \\
66.5^{*} \\
73.1\end{array}$ & $\begin{array}{l}17.4^{*} \\
14.6 \\
10.8\end{array}$ & $\begin{array}{l}25.0^{*} \\
18.9 \\
16.2\end{array}$ & $\begin{array}{l}250 \\
604 \\
253\end{array}$ & $\begin{array}{l}66.4^{*} \\
65.4^{*} \\
76.6\end{array}$ & $\begin{array}{r}76 \\
133 \\
37\end{array}$ & $\begin{array}{l}27.1^{*} \\
35.9^{*} \\
41.8^{*}\end{array}$ & $\begin{array}{r}103 \\
174 \\
54\end{array}$ & $\begin{array}{l}7.6 \\
8.9 \\
9.6\end{array}$ \\
\hline $\begin{array}{l}\text { Race/ethnicity } \\
\text { Hispanic } \\
\text { Black, non-Hispanic } \\
\text { White, non-Hispanic }^{\dagger} \\
\text { Other, non-Hispanic }\end{array}$ & $\begin{array}{l}421 \\
238 \\
878 \\
147\end{array}$ & $\begin{array}{l}67.4 \\
64.5 \\
63.2 \\
69.7\end{array}$ & $\begin{array}{c}16.8 \\
13.3 \\
15.9 \\
7.0^{*}\end{array}$ & $\begin{array}{l}15.8 \\
22.3 \\
21.0 \\
23.3\end{array}$ & $\begin{array}{l}287 \\
156 \\
562 \\
102\end{array}$ & $\begin{array}{l}75.5^{*} \\
54.9^{*} \\
70.1 \\
63.4^{*}\end{array}$ & $\begin{array}{r}69 \\
31 \\
136 \\
10\end{array}$ & $\begin{array}{l}26.6^{*} \\
21.3^{*} \\
39.4 \\
\ldots \S\end{array}$ & $\begin{array}{r}65 \\
51 \\
180 \\
35\end{array}$ & $\begin{array}{l}9.4 \\
5.4 \\
9.3 \\
9.0\end{array}$ \\
\hline $\begin{array}{l}\text { Education } \\
<\text { College degree } \\
\text { College degree } \\
>\text { College degree }^{\dagger}\end{array}$ & $\begin{array}{l}807 \\
661 \\
216\end{array}$ & $\begin{array}{l}61.4^{*} \\
67.8 \\
70.4\end{array}$ & $\begin{array}{l}16.0 \\
13.0 \\
15.5\end{array}$ & $\begin{array}{l}22.7^{*} \\
19.2^{*} \\
14.1\end{array}$ & $\begin{array}{l}501 \\
454 \\
152\end{array}$ & $\begin{array}{l}60.1^{*} \\
74.7 \\
75.1\end{array}$ & $\begin{array}{r}130 \\
83 \\
33\end{array}$ & $\begin{array}{l}26.1^{*} \\
33.7^{*} \\
64.1\end{array}$ & $\begin{array}{r}176 \\
124 \\
31\end{array}$ & $\begin{array}{c}6.6^{*} \\
9.8^{*} \\
15.3\end{array}$ \\
\hline $\begin{array}{l}\text { Married } \\
\text { Yes }^{\dagger} \\
\text { No }\end{array}$ & $\begin{array}{r}1,101 \\
583\end{array}$ & $\begin{array}{l}67.4 \\
60.8^{*}\end{array}$ & $\begin{array}{l}14.3 \\
15.6\end{array}$ & $\begin{array}{l}18.3 \\
23.6^{*}\end{array}$ & $\begin{array}{l}749 \\
358\end{array}$ & $\begin{array}{l}71.5 \\
61.2^{*}\end{array}$ & $\begin{array}{r}156 \\
90\end{array}$ & $\begin{array}{l}36.1 \\
29.6^{*}\end{array}$ & $\begin{array}{l}196 \\
135\end{array}$ & $\begin{array}{l}8.1 \\
9.0\end{array}$ \\
\hline $\begin{array}{l}\text { Insurance coverage } \\
\text { Private/military only }{ }^{\dagger} \\
\text { Any public } \\
\text { No insurance }\end{array}$ & $\begin{array}{r}936 \\
695 \\
53\end{array}$ & $\begin{array}{l}65.3 \\
65.9 \\
46.0^{*}\end{array}$ & $\begin{array}{l}15.2 \\
14.2 \\
16.2\end{array}$ & $\begin{array}{l}19.5 \\
19.9 \\
37.8^{*}\end{array}$ & $\begin{array}{r}619 \\
463 \\
25\end{array}$ & $\begin{array}{r}71.7 \\
63.9 \\
-\S\end{array}$ & $\begin{array}{r}139 \\
99 \\
8\end{array}$ & $\begin{array}{r}39.7 \\
24.9 \\
-\S\end{array}$ & $\begin{array}{r}178 \\
133 \\
20\end{array}$ & $\begin{array}{l}9.6 \\
8.4 \\
-\$\end{array}$ \\
\hline $\begin{array}{l}\text { Working status" } \\
\text { Yes }^{\dagger} \\
\text { No }\end{array}$ & $\begin{array}{l}932 \\
752\end{array}$ & $\begin{array}{l}67.8 \\
61.5^{*}\end{array}$ & $\begin{array}{l}13.5 \\
16.3\end{array}$ & $\begin{array}{l}18.7 \\
22.2\end{array}$ & $\begin{array}{l}639 \\
468\end{array}$ & $\begin{array}{l}72.8 \\
61.5^{*}\end{array}$ & $\begin{array}{l}123 \\
123\end{array}$ & $\begin{array}{l}39.6 \\
27.6^{*}\end{array}$ & $\begin{array}{l}170 \\
161\end{array}$ & $\begin{array}{l}11.4 \\
5.6^{*}\end{array}$ \\
\hline $\begin{array}{l}\text { Poverty status** } \\
\text { At or above poverty }{ }^{\dagger} \\
\text { Below poverty }\end{array}$ & $\begin{array}{r}1,328 \\
353\end{array}$ & $\begin{array}{l}67.8 \\
61.5^{*}\end{array}$ & $\begin{array}{l}15.2 \\
13.4\end{array}$ & $\begin{array}{l}18.4 \\
26.5^{*}\end{array}$ & $\begin{array}{l}889 \\
217\end{array}$ & $\begin{array}{l}71.0 \\
56.4^{*}\end{array}$ & $\begin{array}{r}198 \\
47\end{array}$ & $\begin{array}{l}37.1 \\
20.7^{*}\end{array}$ & $\begin{array}{r}241 \\
89\end{array}$ & $\begin{array}{l}9.8 \\
5.4\end{array}$ \\
\hline $\begin{array}{l}\text { High-risk conditions }{ }^{\dagger} \\
\text { Yes }^{\dagger} \\
\text { No }\end{array}$ & $\begin{array}{r}655 \\
1,029\end{array}$ & $\begin{array}{l}74.5 \\
58.9^{*}\end{array}$ & $\begin{array}{l}10.1 \\
17.8^{*}\end{array}$ & $\begin{array}{l}26.5 \\
18.4^{*}\end{array}$ & $\begin{array}{l}494 \\
613\end{array}$ & $\begin{array}{l}69.7 \\
66.4\end{array}$ & $\begin{array}{r}66 \\
180\end{array}$ & $\begin{array}{l}32.6 \\
33.8\end{array}$ & $\begin{array}{r}95 \\
236\end{array}$ & $\begin{array}{l}9.5 \\
8.1\end{array}$ \\
\hline
\end{tabular}

See table footnotes on the next page.

if a woman's decision to participate in this particular survey were related to receipt of vaccination. Fourth, the composite variables computed for attitudes toward influenza vaccination and infection were not validated. Despite these limitations, the opt-in Internet panel survey can provide timely estimates of influenza vaccination coverage and in-depth information about knowledge, attitudes, behaviors, and barriers related to influenza vaccination among pregnant women. Trends in vaccination coverage reported from the Internet panel surveys have been consistent with those reported from less timely probability sampling surveys (9).

The data from the current analysis demonstrate that to improve vaccination coverage, pregnant women receiving a provider recommendation for and offer of influenza vaccination is important, as is clinic-based education about the safety and efficacy of vaccination toward pregnant women. Missed opportunities for vaccination can be reduced by implementing standing orders that enable appropriately trained health personnel to administer vaccinations without the need for examination or a direct order from the provider at the time of the interaction, and provider reminders to ensure influenza vaccination is recommended and offered at each visit before and during pregnancy. Providing referrals in situations where a provider is unable to offer vaccination could help pregnant women receive influenza vaccination. Many unvaccinated women in this survey reported receiving a provider recommendation or offer to be vaccinated yet reported being unvaccinated, emphasizing the need for clinic-based education to address concerns about vaccination during pregnancy. Resources are available from CDC (http://www.cdc.gov/flu/protect/vaccine/pregnant.htm) to help providers communicate the risk for influenza and benefits of vaccination for pregnant women. 
TABLE 2. (Continued) Percentage of women receiving a provider recommendation/offer of influenza vaccination and influenza vaccination coverage, by provider recommendation and offer of influenza vaccination, among women who visited a provider at least one time since July 2014 and who were pregnant any time during October 2014-January 2015 - Internet panel survey, United States, 2014-15 influenza season

\begin{tabular}{|c|c|c|c|c|c|c|c|c|c|c|}
\hline \multirow[b]{3}{*}{ Characteristic } & \multirow{3}{*}{$\begin{array}{c}\text { Unweighted } \\
\text { no. }\end{array}$} & \multicolumn{3}{|c|}{$\begin{array}{l}\text { Provider recommendation/offer of influenza } \\
\text { vaccination }\end{array}$} & \multicolumn{6}{|c|}{ Vaccination coverage } \\
\hline & & \multirow{2}{*}{$\begin{array}{c}\text { Recommendec } \\
\text { offered, } \\
\text { weighted } \\
\%\end{array}$} & \multirow{2}{*}{$\begin{array}{c}\text { commended, } \\
\text { no offer, } \\
\text { weighted } \\
\%\end{array}$} & \multirow{2}{*}{$\begin{array}{c}\text { No } \\
\text { recommendation, } \\
\text { weighted } \%\end{array}$} & \multicolumn{2}{|c|}{$\begin{array}{c}\text { Provider } \\
\text { recommended, } \\
\text { offered }\end{array}$} & \multicolumn{2}{|c|}{$\begin{array}{c}\text { Provider } \\
\text { recommended, } \\
\text { no offer }\end{array}$} & \multicolumn{2}{|c|}{ No recommendation } \\
\hline & & & & & $\begin{array}{l}\text { Unweighted } \\
\text { no. }\end{array}$ & $\begin{array}{l}\text { Weighted } \\
\%\end{array}$ & $\begin{array}{l}\text { Unweighted } \\
\text { no. }\end{array}$ & $\begin{array}{l}\text { Weighted } \\
\%\end{array}$ & $\begin{array}{l}\text { Unweighted } \\
\text { no. }\end{array}$ & $\begin{array}{l}\text { Weighted } \\
\%\end{array}$ \\
\hline \multicolumn{11}{|c|}{ No. of visits to a provider since July } \\
\hline $1-5$ & 399 & $48.1^{*}$ & 16.0 & $35.9^{*}$ & 194 & $61.1^{*}$ & 62 & 32.5 & 143 & 7.6 \\
\hline $6-10$ visits & 657 & $66.1^{*}$ & 15.1 & $18.9^{*}$ & 446 & $72.5^{*}$ & 96 & 35.8 & 115 & 9.4 \\
\hline$>10$ visits $^{\dagger}$ & 628 & 74.4 & 13.8 & 11.8 & 467 & 66.4 & 88 & 31.7 & 73 & 8.6 \\
\hline \multicolumn{11}{|c|}{ Attitude toward efficacy of influenza vaccination $\S^{\S}$} \\
\hline Positive $^{\dagger}$ & 1,293 & 69.8 & 13.3 & 16.9 & 913 & 78.2 & 170 & 45.6 & 210 & 12.1 \\
\hline Negative & 391 & $49.2^{*}$ & $19.7^{*}$ & $31.1^{*}$ & 194 & $21.0^{*}$ & 76 & $7.5^{*}$ & 121 & $2.2^{*}$ \\
\hline \multicolumn{11}{|c|}{ Attitude toward safety of influenza vaccination ใ१ } \\
\hline Positive $^{\dagger}$ & 1,268 & 71.1 & 13.6 & 15.4 & 907 & 78.2 & 170 & 43.4 & 210 & 14.1 \\
\hline Negative & 416 & $47.2^{*}$ & 18.4 & $34.4^{*}$ & 200 & $21.0^{*}$ & 76 & $12.6^{*}$ & 121 & $1.2^{*}$ \\
\hline \multicolumn{11}{|c|}{ Attitude toward influenza infection ${ }^{* * *}$} \\
\hline Concerned $^{\dagger}$ & 1,134 & 68.4 & 14.2 & 17.4 & 907 & 71.7 & 157 & 39.7 & 190 & 10.1 \\
\hline Not concerned & 550 & $57.8^{*}$ & 16.0 & $26.3^{*}$ & 200 & $58.4^{*}$ & 89 & $22.1^{*}$ & 141 & 6.2 \\
\hline
\end{tabular}

$* 2$ percentage point difference compared with reference group.

† Reference group for comparisons within subgroups.

$\S$ Vaccination coverage estimate was not reliable because sample size was $<30$.

"Working status, Yes = those employed for wages and self-employed; No = those out of work, homemakers, students, retired, or unable to work.

** Below poverty $=$ a total family income of $<\$ 24,008$ for a family of four with two minors as of 2014 , as categorized by the U.S. Census Bureau (https://www.census. gov/hhes/www/poverty/data/threshld/).

${ }^{+\dagger}$ Conditions associated with increased risk for serious medical complication from influenza, including chronic asthma, a lung condition other than asthma, a heart condition, diabetes, a kidney condition, a liver condition, obesity, or a weakened immune system caused by a chronic illness or by medicines taken for a chronic illness.

$\S \S$ Created based on two questions regarding attitudes toward the efficacy of flu vaccination: 1 ) "Flu vaccine is somewhat/very effective in preventing flu," and 2 ) “Flu vaccine a pregnant women received is somewhat/very effective in protecting her baby from the flu." A 1-point score was given for each "yes" answer for either of the two questions. "Positive" attitude = summary score of 1 or 2 ; "Negative" attitude = summary score of 0 .

१ๆ Created based on three questions regarding attitudes toward the safety of flu vaccination: 1)"Flu vaccination is somewhat/very/completely safe for most adult women"; 2) "Flu vaccination is somewhat/very/completely safe for pregnant women"; and 3) "Flu vaccination that a pregnant woman receives is somewhat/very/ completely safe for her baby." A 1-point score was given for each "yes" answer for any of the 3 questions. "Positive" attitude = summary score of 2 or 3 ; "Negative" attitude = summary score of 0 or 1 .

*** Created based on three questions regarding attitude toward flu infection: 1) "If a pregnant woman gets the flu, it is somewhat/very likely to harm the baby"; 2 ) "Flu infection during pregnancy somewhat/very likely harms pregnant women"; and 3) "somewhat/very worried about getting sick with the flu this season." A 1-point score was given for each "yes" answer for any of the 3 questions. "Concerned" = summary score of 2 or 3; "Not concerned" = summary score of 1 or 0.

${ }^{1}$ Eagle Medical Services, LLC, San Antonio, Texas; ${ }^{2}$ Immunization Services Division, National Center for Immunization and Respiratory Diseases, CDC; ${ }^{3}$ Abt Associates, Inc., Cambridge, Massachusetts; ${ }^{4}$ Leidos, Atlanta, Georgia; ${ }^{5} \mathrm{Oak}$ Ridge Institute for Science and Education (ORISE) fellow, CDC; ${ }^{6}$ Influenza Division, National Center for Immunization and Respiratory Diseases, CDC; ${ }^{7}$ Division of Reproductive Health, National Center for Chronic Disease Prevention and Health Promotion, CDC; ${ }^{8}$ Abt SRBI, New York, New York.

Corresponding author: Helen Ding, hding@cdc.gov, 404-639-8513.

\section{References}

1. CDC. Prevention and control of influenza with vaccines: recommendations of the Advisory Committee on Immunization Practices (ACIP), United States, 2013-14. MMWR Recomm Rep 2013;62(No. RR-07):1-43.

2. American Congress of Obstetricians and Gynecologists Committee on Obstetric Practice and Immunization Expert Work Group. ACOG committee opinion no. 468: influenza vaccination during pregnancy. Obstet Gynecol 2014;124:648-51.

3. Ding H, Black CL, Ball S, et al. Influenza vaccination coverage among pregnant women-United States, 2013-14 influenza season. MMWR Morb Mortal Wkly Rep 2014;63:816-21.
4. The Community Preventive Services Task Force. Increasing appropriate vaccination: health care system-based interventions implemented in combination. Washington, DC: US Department of Health and Human Services, the Community Preventive Services Task Force; 2015. Available at http://www.thecommunityguide.org/vaccines/healthsysteminterventions.html.

5. American College of Obstetricians and Gynecologists. ACOG committee opinion no. 558: Integrating immunizations into practice. Obstet Gynecol 2013;121:897-903.

6. Lindley MC, Wortley PM, Winston CA, Bardenheier BH. The role of attitudes in understanding disparities in adult influenza vaccination. Am J Prev Med 2006;31:281-5.

7. Fiscella K. Commentary-anatomy of racial disparity in influenza vaccination. Health Serv Res 2005;40:539-49.

8. Flannery B, Clippard J, Zimmerman RK, et al. Early estimates of seasonal influenza vaccine effectiveness-United States, January 2015. MMWR Morb Mortal Wkly Rep 2015;64:10-5.

9. Lu P-J, Santibanez TA, Williams WW, et al. Surveillance of influenza vaccination coverage-United States, 2007-2008 through 2011-12 influenza seasons. MMWR Surveill Summ 2013;62(No. SS-04):1-28. 


\title{
Clinical Inquiries Received by CDC Regarding Suspected Ebola Virus Disease in Children — United States, July 9, 2014-January 4, 2015
}

\author{
Alyson B. Goodman, MD ${ }^{1,2}$; Elissa Meites, MD ${ }^{1,3}$; Erica H. Anstey, PhD ${ }^{1,4}$; Kathleen E. Fullerton, $\mathrm{MPH}^{1,5}$; Achala Jayatilleke, PhD ${ }^{1,5}$; Wendy Ruben, \\ MS $^{1,2}$; Emily Koumans, MD ${ }^{1,6}$; Alexandra M. Oster, MD ${ }^{1,3}$; Mateusz P. Karwowski, MD ${ }^{1,7,8}$; Eric Dziuban, MD ${ }^{1,6}$; Robert D. Kirkcaldy, MD ${ }^{1,3}$; \\ Maleeka Glover, ScD ${ }^{1,9}$; Luis Lowe, MS, MPH ${ }^{1,10}$; Georgina Peacock, MD ${ }^{1,2}$; Barbara Mahon, MD ${ }^{1,10}$; Stephanie E. Griese, MD ${ }^{1,11}$
}

The 2014-2015 Ebola virus disease (Ebola) epidemic is the largest in history and represents the first time Ebola has been diagnosed in the United States (1,2). On July 9, 2014, CDC activated its Emergency Operations Center and established an Ebola clinical consultation service to assist U.S. state and local public health officials and health care providers with the evaluation of suspected cases. CDC reviewed all 89 inquiries received by the consultation service during July $9,2014-$ January 4, 2015, about children (persons aged $\leq 18$ years). Most (56 [63\%]) children had no identifiable epidemiologic risk factors for Ebola; among the $33(37 \%)$ who did have an epidemiologic risk factor, in every case this was travel from an Ebola-affected country. Thirty-two of these children met criteria for a person under investigation (PUI) because of clinical signs or symptoms $(3,4)$. Fifteen PUIs had blood samples tested for Ebola virus RNA by reverse transcription-polymerase chain reaction; all tested negative. Febrile children who have recently traveled from an Ebola-affected country can be expected to have other common diagnoses, such as malaria and influenza, and in the absence of epidemiologic risk factors for Ebola, the likelihood of Ebola is extremely low. Delaying evaluation and treatment for these other more common illnesses might lead to poorer clinical outcomes. Additionally, many health care providers expressed concerns about whether and how parents should be allowed in the isolation room. While maintaining an appropriate level of vigilance for Ebola, public health officials and health care providers should ensure that pediatric PUIs receive timely triage, diagnosis, and treatment of other more common illnesses, and care reflecting best practices in supporting children's psychosocial needs (5).

CDC's Emergency Operations Center was activated to respond to the Ebola outbreak in West Africa. A clinical consultation service was established to assist state and local health departments and health care providers evaluate persons possibly at risk for Ebola. Children with any signs or symptoms consistent with Ebola (fever, nausea, vomiting, headache, diarrhea, abdominal pain, muscle pain, fatigue, or unexplained bleeding) and an epidemiologic risk factor (i.e., exposure to a person with Ebola or travel from an affected country during the 21 days before symptom onset) were considered PUIs $(3,4)$. Ebola assessment can take $\geq 3$ days, because the diagnosis cannot be ruled out until a blood specimen obtained 72 hours after symptom onset is negative for Ebola (G). Ebola testing might not be necessary if an alternative diagnosis is made or if symptoms resolve. All domestic Ebola diagnoses are confirmed at CDC or at local or state public health laboratories, most of which are part of the CDC Laboratory Response Network (7). All Ebola-related inquiries about children during July 9, 2014-January 4, 2015 were reviewed, including call logs and e-mails, as well as databases that contain the inquiry source, demographic information, epidemiologic risk factors, clinical presentation and course, isolation measures, Ebola virus test results, and discharge diagnoses, if available (3).

During July 9, 2014-January 4, 2015, CDC responded to clinical inquiries regarding 89 children in 27 states and the District of Columbia. CDC received an average of 1-2 Ebolarelated inquiries about children per week (range $=$ zero to eight) before September 30, 2014, when CDC confirmed the first imported Ebola case identified in the United States (Figure) (2). In the subsequent 4 weeks, calls increased, with CDC receiving an average of 12 pediatric Ebola-related inquiries per week $($ range $=$ five to 25$)$. However, only 20\% (10 of 49) of these inquiries turned out to involve actual PUIs, significantly lower than the $55 \%$ (22 of $40[\mathrm{p}<0.01])$ of pediatric Ebola-related inquires that involved PUIs during all other weeks combined.

Overall, 57 (64\%) children about whom an Ebola-related inquiry was made did not meet PUI criteria. Among these, 56 had no identifiable epidemiologic risk factors for Ebola but nevertheless were perceived by the inquirer to be at risk. The most common misperception about risk involved confusion about which countries were affected by Ebola: 30 (54\%) children had traveled from an unaffected country, seven (12\%) had contact with a traveler from an unaffected country, and $15(27 \%)$ were perceived erroneously to have been exposed to Ebola inside the United States. Most of these inquiries (49 of 56) were initiated by a health care provider; most (37) occurred during the 4 weeks after the first Ebola case was diagnosed in the United States.

Demographic characteristics were similar for children with and without epidemiologic risk factors (Table 1). Among 33 children with an epidemiologic risk factor for Ebola, all had traveled to an Ebola-affected country, and none had known contact with an Ebola patient; 32 (97\%) also had one or more signs or symptoms consistent with Ebola and thus were 


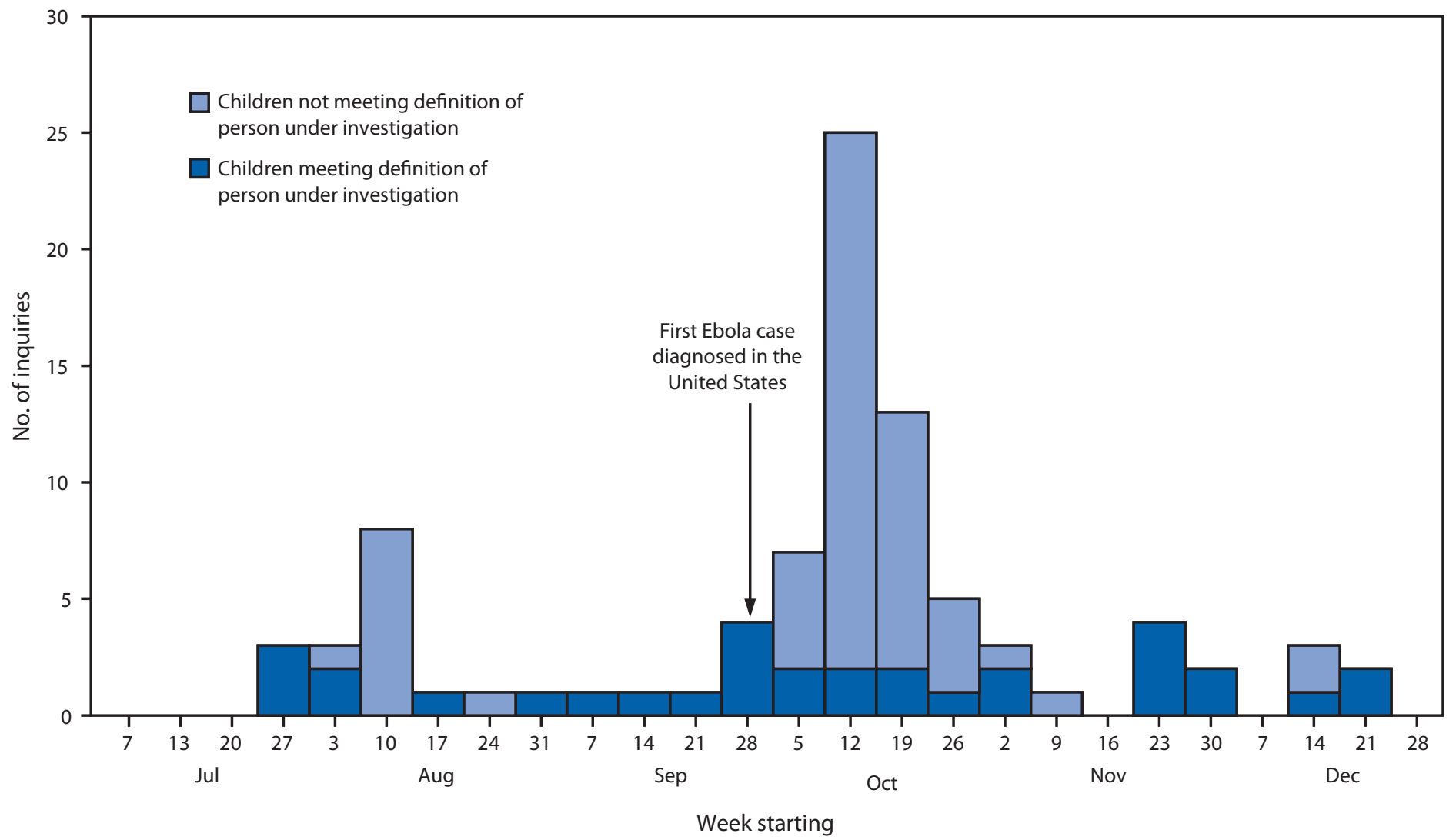

considered PUIs. Fifteen (47\%) of the 32 PUIs were tested for Ebola, and all tested negative. The most frequently reported sign or symptom among the 32 PUIs was subjective or objective fever $(25$ [78\%]). Eight (25\%) children had signs or symptoms suggestive of an alternative diagnosis, such as an upper respiratory tract infection (Table 2). Discharge diagnosis information was available for 19 (59\%) PUIs; diagnoses included malaria (five), influenza (five), other viral illness (three), and other nonviral illness (six).

At health care facilities, at least 15 PUIs were placed in some form of isolation during evaluation, and at least 10 were transferred to another hospital for Ebola assessment. Intensive care was required for at least three children while they were being evaluated; diagnoses included malaria, dehydration, and nonspecific viral illness. Written records suggest that appropriate clinical care was delayed for at least five children, either because of difficulty finding a hospital to evaluate a pediatric PUI or hospital reluctance to perform testing in the laboratory for illnesses such as malaria and influenza, because of concern about potential laboratory contamination or exposure of staff members to Ebola. One PUI who received routine vaccinations within 21 days of travel from an Ebola-affected country developed a fever 2 days later and required a full clinical evaluation to determine whether the fever was related to the vaccines, Ebola, or another travel-related illness. During pediatric Ebola assessments, many health care providers expressed concerns about whether children's parents should be permitted in the isolation room and how to manage their presence. Health care facility challenges included a lack of established policies about parental presence with children in isolation, limited supplies of personal protective equipment (PPE), lack of available staff to supervise parental donning and doffing of PPE, and insufficient time to teach parents proper PPE use. In several instances, cell phone or laptop-based video connections were used to connect isolated school-aged children with their relatives in another room.

\section{Discussion}

Pediatric clinical care presents unique challenges during an Ebola assessment $(5,8)$, and routine pediatric care for common pediatric illnesses (e.g., bacterial and viral infections, or malaria, a disease that is endemic in West Africa) was sometimes delayed because of concerns about Ebola. No child evaluated for Ebola had any known contact with an Ebola patient or their body fluids, or with a deceased patient, and to date, no pediatric Ebola case has been identified or managed in the United 
TABLE 1. Characteristics of children (aged $\leq 18$ years) about whom CDC received an Ebola-related clinical inquiry — United States, July 9 , 2014-January 4, 2015

\begin{tabular}{|c|c|c|c|c|c|c|}
\hline \multirow[b]{3}{*}{ Characteristic } & \multicolumn{2}{|c|}{ All children } & \multicolumn{2}{|c|}{$\begin{array}{l}\text { Children with any epidemiologic } \\
\text { risk factor for Ebola }\end{array}$} & \multicolumn{2}{|c|}{ Children tested for Ebola } \\
\hline & No. & (\%) & No. & (\%) & No. & (\%) \\
\hline & 89 & $(100)$ & 33 & $(100)$ & 15 & $(100)$ \\
\hline \multicolumn{7}{|l|}{ Age group (yrs) } \\
\hline $0-4$ & 28 & $(31)$ & 9 & (27) & 3 & (20) \\
\hline $5-12$ & 41 & $(46)$ & 14 & (43) & 7 & (47) \\
\hline $13-18$ & 14 & (16) & 8 & (24) & 4 & (26) \\
\hline Not reported & 6 & (7) & 2 & (6) & 1 & (7) \\
\hline \multicolumn{7}{|l|}{ Sex } \\
\hline Male & 46 & $(52)$ & 15 & (45) & 5 & (33) \\
\hline Female & 35 & (39) & 17 & (52) & 9 & (60) \\
\hline Not reported & 8 & (9) & 1 & (3) & 1 & (7) \\
\hline \multicolumn{7}{|l|}{ Epidemiologic risk factor } \\
\hline Travel from an Ebola-affected country* within 21 days & 33 & (37) & 33 & $(100)$ & 15 & (100) \\
\hline Contact with an Ebola patient or patient's body fluids & 0 & - & 0 & - & 0 & - \\
\hline None & 56 & $(63)$ & 0 & - & 0 & - \\
\hline \multicolumn{7}{|l|}{ Person under investigation (PUI) status } \\
\hline Met PUI criteria & 32 & (36) & 32 & (97) & 15 & $(100)$ \\
\hline Did not meet PUI criteria & 57 & (64) & 1 & (3) & 0 & - \\
\hline \multicolumn{7}{|l|}{ Ebola testing } \\
\hline Positive & 0 & - & 0 & - & 0 & - \\
\hline Negative & 15 & (17) & 15 & $(45)$ & 15 & $(100)$ \\
\hline Not tested & 74 & (83) & 18 & (55) & NA & NA \\
\hline \multicolumn{7}{|l|}{ Source of inquiry } \\
\hline Health care provider & 66 & (74) & 17 & (51) & 5 & (33) \\
\hline State or local health department & 23 & (26) & 16 & (49) & 10 & (67) \\
\hline
\end{tabular}

Abbreviation: $\mathrm{NA}=$ not available.

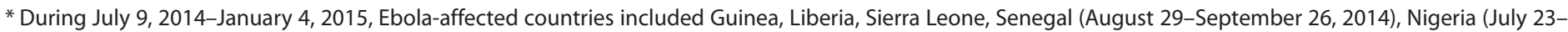
September 30, 2014), and Mali (October 24, 2014-January 4, 2015).

States. In light of this low risk, children can be expected to have other more common causes of febrile illness, and delaying evaluation and treatment of these other diagnoses might lead to poorer clinical outcomes. Malaria and influenza should be considered in the differential diagnosis of fever in travelers, and early testing and treatment can prevent severe illness (5). Furthermore, recent travelers and immigrant children, in particular, have specific health care needs, such as routine and catch-up vaccinations. Vaccine providers should be aware of the potential for vaccine-associated fever and can consult their local or state health department for assistance in weighing the benefits and risks of administering routine vaccinations to children who are under active monitoring for Ebola because they have traveled to the United States from an affected area during the preceding 21 days.

Children, especially those who are young or who have developmental delays, are dependent upon caregivers to provide physical, emotional, and social support. The presence of a parent or caregiver in the examination room during the clinical assessment for Ebola might be important for many pediatric patients, especially very young children. Risks and benefits of parental presence should be considered on a case-by-case basis. Parents or caregivers who provide bedside support to a child in isolation for an Ebola assessment should use PPE consistently, correctly, and in accordance with CDC guidance, state or local health department recommendations, and facility policies (9). Health care facilities that might perform pediatric Ebola assessments can anticipate and plan for issues specifically related to caring for a child, including establishing policies and plans for parental presence, PPE use, and communication. Transfers of pediatric patients between facilities for Ebola-related care involve challenges related to communication between clinical teams and health departments, infection control during transport, operations coordination, and other concerns $(9,10)$.

Although the weekly number of pediatric PUIs varied little, the number of clinical inquiries related to children increased sharply during the month after the first domestic Ebola case (Figure). Most of these children did not meet PUI criteria, but all inquiries required rapid, accurate, and complete evaluation. By anticipating and planning for surges, public health officials can scale responses to meet changing community needs. Proactive steps, including clear and consistent risk communication, timely clinician education, and broad community outreach might reduce public misperception about Ebola risk and lessen strain on clinical and public health resources. 
TABLE 2. Clinical presentation of children (aged $\leq 18$ years) about whom CDC received an Ebola-related clinical inquiry - United States, July 9, 2014-January 4, 2015

\begin{tabular}{|c|c|c|c|c|c|c|}
\hline \multirow[b]{3}{*}{ Characteristic } & \multicolumn{2}{|c|}{ All children } & \multicolumn{2}{|c|}{$\begin{array}{l}\text { Children with any epidemiologic } \\
\text { risk factor for Ebola }\end{array}$} & \multicolumn{2}{|c|}{ Children tested for Ebola } \\
\hline & No. & $(\%)$ & No. & (\%) & No. & $(\%)$ \\
\hline & 89 & (100) & 33 & $(100)$ & 15 & (100) \\
\hline \multicolumn{7}{|l|}{ Signs or symptoms reported* } \\
\hline Any & 78 & (88) & 32 & (97) & 15 & $(100)$ \\
\hline Elevated body temperature or fever & 63 & (81) & 25 & (78) & 14 & (93) \\
\hline Vomiting & 21 & (27) & 7 & (22) & 5 & (33) \\
\hline Headache & 16 & (21) & 6 & (19) & 5 & (33) \\
\hline Diarrhea & 14 & (18) & 4 & (13) & 1 & (7) \\
\hline Abdominal pain & 12 & (15) & 5 & (16) & 2 & (13) \\
\hline Nausea & 9 & (12) & 1 & (3) & 1 & (7) \\
\hline Muscle pain & 7 & (9) & 3 & (9) & 1 & (7) \\
\hline Fatigue & 4 & (5) & 1 & (3) & 0 & - \\
\hline Unexplained hemorrhage & 3 & (4) & 0 & - & 0 & - \\
\hline Upper respiratory symptoms† & 15 & (19) & 8 & (25) & 4 & (27) \\
\hline Other & 19 & (24) & 8 & (25) & 5 & (33) \\
\hline \multicolumn{7}{|l|}{ Discharge diagnosis } \\
\hline Malaria & 11 & (12) & 5 & (15) & 4 & (27) \\
\hline Influenza & 7 & $(8)$ & 5 & (15) & 3 & (20) \\
\hline Other, viral illness & 7 & (8) & 3 & (9) & 2 & (13) \\
\hline Other, nonviral illness & 9 & (10) & 6 & (18) & 0 & - \\
\hline Not available & 55 & (62) & 14 & (43) & 6 & $(40)$ \\
\hline
\end{tabular}

* Might total $>100 \%$ because patients could have multiple reported signs or symptoms; for specific symptoms, percentage denominator is children with any symptoms reported.

† Upper respiratory symptoms include rhinorrhea, nasal congestion, or cough.

The findings in this report are subject to at least two limitations. First, clinical data and information regarding isolation and PPE were collected as part of a public health emergency response, and information on certain variables (e.g., symptoms, suspected exposure, and alternative diagnoses) might be incomplete. Second, although this report describes all domestic Ebola-related pediatric clinical inquiries to CDC, it might not include all inquiries to health departments.

During this epidemic, CDC, state and local public health departments, and health care providers developed strategies to monitor travelers and others who might be at risk for Ebola. The goals are to quickly isolate and evaluate PUIs, including children, to ensure that patients receive timely care while minimizing transmission risk. CDC provides up-to-date information about Ebola online at http://www.cdc.gov/vhf/ebola. While maintaining a high level of vigilance for Ebola among ill pediatric patients who have recently travelled from affected countries, U.S. public health officials and health care providers should provide child-focused care that includes timely diagnosis and appropriate treatment of common pediatric illnesses, as well as Ebola, and reflects overall best practices in supporting children's psychosocial needs.

\section{Summary}

What is already known on this topic?

The current epidemic of Ebola virus disease (Ebola) is the largest in history and represents the first time Ebola has been diagnosed in the United States. CDC's Emergency Operations Center offers consultation to state and local health departments and health care providers assessing adults and children for Ebola.

What is added by this report?

During July 9, 2014-January 4, 2015, CDC responded to clinical inquiries regarding 89 children in the United States. Only 33 had an epidemiologic risk factor; 15 were tested for Ebola. All were negative. Medical evaluation and treatment for other conditions were sometimes delayed while the child underwent Ebola assessment. Additionally, health care providers and hospitals expressed concerns about allowing parents in the isolation room.

What are the implications for public health practice?

Public health and health care providers in the United States, while maintaining a high level of vigilance for Ebola among ill pediatric patients, should be prepared to provide child-focused care that includes timely diagnosis and treatment of common pediatric illnesses, as well as Ebola, and reflects overall best practices in supporting children's psychosocial needs. Parents or caregivers who provide bedside support to a child in isolation for Ebola evaluation should use personal protective equipment in accordance with CDC guidance, health department recommendations, and facility policies. 


\section{Acknowledgments}

Justin K. Arnold, Brenda Kinsella Balch, Michael Bartenfeld, Stephanie Bialek, Dianna Blau, Virginia B. Bowen, Timothy Campbell, Cristina Cardemil, Joseph Sean Cavanaugh, Steven W. Champaloux, Michelle S. Chevalier, Jennifer R. Cope, Whitni Davidson, Deborah Dowell, Lauren E. Finn, Anne Marie France, Scott Gardner, Shikha Garg, Jacqueline Gindler, Konrad Hayashi, Cindy Hinton, Susan Hocevar, Christopher Hsu, Brendan Jackson, Pallavi A. Kache, Barbara Knust, Shirley Lecher, Rebecca Levine, Benjamin A. Levy, Paul Mead, Ryan Maddox, Stephen Morris, Karen Neil, Bernadette Ng'eno, Minal K. Patel, Brett W. Petersen, John Pettay, David A. Price, Mark Rayfield, Don Sharp, Kanta Sircar, Charnetta L. Smith, Alaina Steck, Ute Ströher, Christopher A. Taylor, Chris Van Beneden, Laura Wilkinson, Jennifer Williams.

${ }^{1} 2014-2015$ Ebola Response, CDC; ${ }^{2}$ National Center on Birth Defects and Developmental Disabilities, CDC; ${ }^{3}$ National Center for HIV/AIDS, Viral Hepatitis, STD, and TB Prevention, CDC; ${ }^{4}$ National Center for Chronic Disease Prevention and Health Promotion, CDC; ${ }^{5}$ Center for Surveillance, Epidemiology, and Laboratory Services, CDC; ${ }^{6}$ Center for Global Health, CDC; ${ }^{7}$ Epidemic Intelligence Service, CDC; ${ }^{8}$ National Center for Environmental Health, CDC; ${ }^{9}$ Office of Infectious Diseases, CDC; ${ }^{10}$ National Center for Emerging and Zoonotic Infectious Diseases, CDC; ${ }^{11}$ Office of Public Health Preparedness and Response, CDC.

Corresponding author: Alyson B. Goodman, iym3@cdc.gov, 404-498-6269.

\section{References}

1. CDC. 2014 Ebola outbreak in West Africa. Available at http://www. cdc.gov/vhf/ebola/outbreaks/2014-west-africa/index.html.

2. Karwowski MP, Meites E, Fullerton KE, et al. Clinical inquiries regarding Ebola virus disease received by CDC_-United States, July 9-November 15, 2014. MMWR Morb Mortal Wkly Rep 2014;63:1175-9.

3. CDC. Epidemiologic risk factors to consider when evaluating a person for exposure to Ebola virus. Available at http://www.cdc.gov/vhf/ebola/ exposure/risk-factors-when-evaluating-person-for-exposure.html.

4. CDC. Case definition for Ebola virus disease (EVD). Available at http:// www.cdc.gov/vhf/ebola/hcp/case-definition.html.

5. Peacock G, Uyeki TM, Rasmussen SA. Ebola virus disease and children: what pediatric health care professionals need to know. JAMA Pediatr 2014;168:1087-8.

6. CDC. Interim guidance for preparing Ebola assessment hospitals. Available at http://www.cdc.gov/vhf/ebola/hcp/preparing-ebolaassessment-hospitals.html.

7. CDC. Interim guidance for specimen collection, transport, testing, and submission for persons under investigation for Ebola virus disease in the United States. Available at http://www.cdc.gov/vhf/ebola/hcp/interim-guidancespecimen-collection-submission-patients-suspected-infection-ebola.html.

8. CDC. Interim U.S. guidance for monitoring and movement of persons with potential Ebola virus exposure. Available at http://www.cdc.gov/ vhf/ebola/exposure/monitoring-and-movement-of-persons-withexposure.html.

9. CDC. Guidance on personal protective equipment to be used by healthcare workers during management of patients with Ebola virus disease in U.S. hospitals, including procedures for putting on (donning) and removing (doffing). Available at http://www.cdc.gov/vhf/ebola/hcp/ procedures-for-ppe.html.

10. CDC. Q\&A's about the transport of pediatric patients ( $<18$ years of age) under investigation or with confirmed Ebola. Available at http://www. cdc.gov/vhf/ebola/healthcare-us/emergency-services/transportingpediatric-patients.html. 


\title{
Update: Influenza Activity — United States and Worldwide, May 24-September 5, 2015
}

\begin{abstract}
Lenee Blanton, $\mathrm{MPH}^{1}$; Krista Kniss, $\mathrm{MPH}^{1}$; Sophie Smith, $\mathrm{MPH}^{1}$; Desiree Mustaquim, $\mathrm{MPH}^{1}$; Craig Steffens, $\mathrm{MPH}^{1}$; Brendan Flannery, PhD ${ }^{1}$; Alicia M. Fry, MD ${ }^{1}$; Joseph Bresee, MD ${ }^{1}$; Teresa Wallis, MS ${ }^{1}$; Rebecca Garten, PhD ${ }^{1}$; Xiyan Xu, MD ${ }^{1}$; Anwar Isa Abd Elal ${ }^{1}$; Larisa Gubareva, PhD ${ }^{1}$; David E. Wentworth, $\mathrm{PhD}^{1}$; Erin Burns, $\mathrm{MA}^{1}$; Jacqueline Katz, $\mathrm{PhD}^{1}$; Daniel Jernigan, $\mathrm{MD}^{1}$; Lynnette Brammer, $\mathrm{MPH}^{1}$
\end{abstract}

During May 24-September 5, 2015,* the United States experienced typical low levels of seasonal influenza activity. Influenza A (H1N1)pdm09 (pH1N1), influenza A (H3N2), and influenza $\mathrm{B}$ viruses were detected worldwide and were identified sporadically in the United States. All of the influenza viruses collected from U.S. states and other countries during that time have been characterized antigenically and/or genetically as being similar to the influenza vaccine viruses recommended for inclusion in the 2015-16 Northern Hemisphere vaccine. During May 24-September 5, 2015, three influenza variant $^{\dagger}$ virus infections were reported; one influenza $\mathrm{A}$ (H3N2) variant virus (H3N2v) from Minnesota in July, one influenza $\mathrm{A}(\mathrm{H} 1 \mathrm{~N} 1)$ variant $(\mathrm{H} 1 \mathrm{~N} 1 \mathrm{v})$ from Iowa in August, and one H3N2v from Michigan in August.

\section{United States}

The U.S. influenza surveillance system ${ }^{\S}$ is a collaboration between CDC and federal, state, local, and territorial partners, and uses eight data sources to collect influenza information,9 six of which operate year-round.

During May 24-September 5, 2015, World Health Organization (WHO) and National Respiratory and Enteric Virus Surveillance System (NREVSS) collaborating laboratories in the United States tested 80,345 specimens for influenza; 1,698 (2.1\%) were positive for influenza (Figure). Of the 1,698 specimens positive for influenza during the summer months of 2015 , a total of $913(54 \%)$ were influenza A viruses, and

\footnotetext{
* Data as of September 11, 2015.

${ }^{\dagger}$ Influenza viruses that circulate in swine are called swine influenza viruses when isolated from swine, but are called variant influenza viruses when isolated from humans. Seasonal influenza viruses that circulate worldwide in the human population have important antigenic and genetic differences from influenza viruses circulating in swine.

$\$$ The CDC influenza surveillance system collects information in five categories from eight data sources: 1) viral surveillance (World Health Organization collaborating laboratories, the National Respiratory and Enteric Virus Surveillance System, and novel influenza A virus case reporting); 2) outpatient illness surveillance (U.S. Outpatient Influenza-Like Illness Surveillance Network); 3) mortality (122 Cities Mortality Reporting System and influenzaassociated pediatric mortality reports); 4) hospitalizations (Influenza Hospitalization Surveillance Network [FluSurv-NET], which includes the Emerging Infections Program and surveillance in three additional states); and 5) summary of the geographic spread of influenza (state and territorial epidemiologist reports).

An overview of influenza surveillance in the United States is available at http:// www.cdc.gov/flu/weekly/overview.htm.
}

785 (46\%) were influenza B viruses. Influenza B viruses were reported slightly more frequently than influenza $A$ viruses from late May until mid-June, and influenza A viruses were more commonly reported from late June through early September. Of the 913 influenza A viruses, 551 (60\%) were subtyped: 28 $(5 \%)$ were $\mathrm{pH} 1 \mathrm{~N} 1$ viruses and $523(95 \%)$ were influenza $\mathrm{A}$ $(\mathrm{H} 3 \mathrm{~N} 2)$ viruses. Influenza viruses were reported from the District of Columbia, Puerto Rico, and 47 states in all 10 U.S. Department of Health and Human Services regions. ${ }^{* *}$

During May 24-September 5, data from the U.S. Outpatient Influenza-Like Illness Surveillance Network (ILINet) indicated that the weekly percentage of outpatient visits to health care providers for influenza-like illness (ILI) ${ }^{\dagger \dagger}$ remained below the national baseline ${ }^{\mathbb{S}}$ of $2.0 \%$, ranging from $0.8 \%$ to $1.3 \%$. The percentage of deaths attributed to pneumonia and influenza (P\&I), as reported by the 122 Cities Mortality Reporting System, did not exceed the epidemic threshold 9 for 2 consecutive weeks and ranged from $5.0 \%$ to $6.4 \%$. A total of four influenza-associated pediatric deaths were reported during May 24-September 5; all were associated with influenza $B$ viruses and occurred during weeks $7,8,17$, and 21 (the weeks ending February 21, February 28, May 2, and May 30, 2015, respectively).

\footnotetext{
** The 10 regions include the following jurisdictions: Region 1: Connecticut, Maine, Massachusetts, New Hampshire, Rhode Island, and Vermont; Region 2: New Jersey, New York, Puerto Rico, and the U.S. Virgin Islands; Region 3: Delaware, District of Columbia, Maryland, Pennsylvania, Virginia, and West Virginia; Region 4: Alabama, Florida, Georgia, Kentucky, Mississippi, North Carolina, South Carolina, and Tennessee; Region 5: Illinois, Indiana, Michigan, Minnesota, Ohio, and Wisconsin; Region 6: Arkansas, Louisiana, New Mexico, Oklahoma, and Texas; Region 7: Iowa, Kansas, Missouri, and Nebraska; Region 8: Colorado, Montana, North Dakota, South Dakota, Utah, and Wyoming; Region 9: Arizona, California, Hawaii, Nevada, American Samoa, Commonwealth of the Northern Mariana Islands, Federated States of Micronesia, Guam, Marshall Islands, and Republic of Palau; Region 10: Alaska, Idaho, Oregon, and Washington.

t† Defined as a temperature of $\geq 100^{\circ} \mathrm{F}\left(\geq 37.8^{\circ} \mathrm{C}\right)$, oral or equivalent, and cough and/or sore throat, without a known cause other than influenza.

$\$ \$$ The national baseline is the mean percentage of visits for ILI during noninfluenza weeks for the previous three seasons plus two standard deviations. Noninfluenza weeks are defined as periods of $\geq 2$ consecutive weeks in which each week accounted for $<2 \%$ of the season's total number of specimens that tested positive for influenza. The national percentage of patient visits for ILI is weighted on the basis of state population.

99 The seasonal baseline proportion of P\&I deaths is projected using a robust regression procedure in which a periodic regression model is applied to the observed percentage of deaths from P\&I that were reported by the 122 Cities Mortality Reporting System during the preceding 5 years. The epidemic threshold is set at 1.645 standard deviations above the seasonal baseline.
} 
FIGURE. Number* and percentage of respiratory specimens testing positive for influenza reported by World Health Organization and National Respiratory and Enteric Virus Surveillance System collaborating laboratories, by type, subtype, and week - United States, September 28, 2014-September 5, 2015

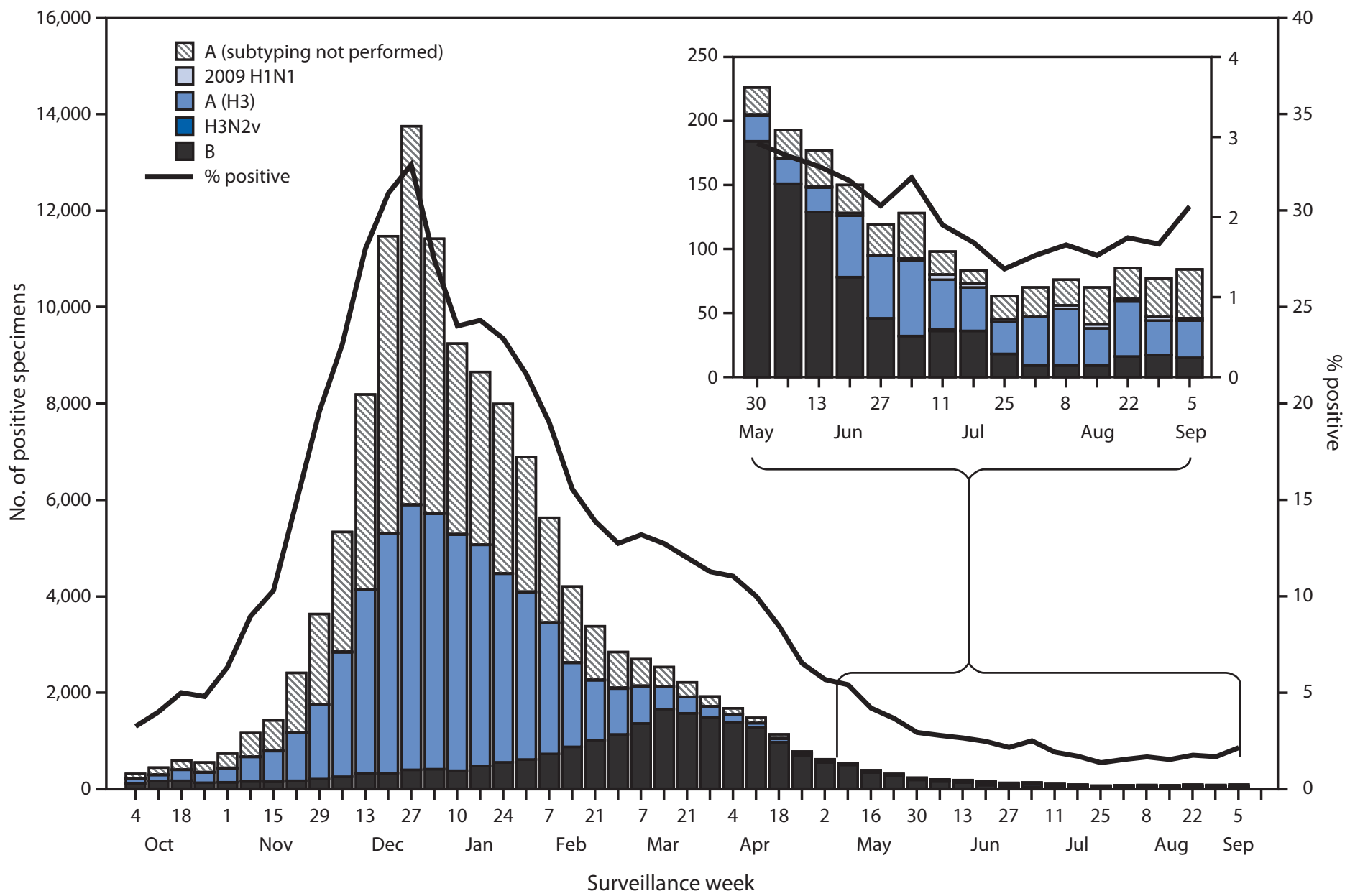

* $\mathrm{N}=127,986$.

† As of September 11, 2015.

\section{Novel Influenza A Virus Infection}

During May 24-September 5, three cases of human infection with novel influenza A viruses were reported. One infection with an $\mathrm{H} 3 \mathrm{~N} 2 \mathrm{v}$ virus was reported by Minnesota in July, one infection with an $\mathrm{H} 1 \mathrm{~N} 1 \mathrm{v}$ virus was reported by Iowa in August, and one infection with an $\mathrm{H} 3 \mathrm{~N} 2 \mathrm{v}$ virus was reported by Michigan in August. All three patients were hospitalized as a result of their illness, but recovered fully. Direct contact with swine in the week preceding illness onset was reported in all three instances. No ongoing community transmission of either virus was detected.

\section{Worldwide}

CDC serves as a WHO Collaborating Center for Surveillance, Epidemiology, and Control of Influenza, one of six WHO Collaborating Centers for Influenza in the WHO Global
Influenza Surveillance and Response System (GISRS) (1). CDC, along with other international public health partners, provide surveillance and virus characterization data to WHO (2). The timing of influenza activity around the world varies depending on the climate of the region. ${ }^{* *}$ Geographic groups of countries, areas, or territories with similar influenza transmission patterns are grouped by influenza transmission zones (2).

\footnotetext{
*** In temperate climates, the onset and peak of influenza activity might vary substantially from one influenza season to the next, but generally begins to increase in the late fall. In the Northern Hemisphere's temperate regions, annual epidemics of influenza typically occur during October-February, but the peak of influenza activity can occur as late as April or May. In temperate regions of the Southern Hemisphere, influenza activity typically peaks during May through August. Although temperate regions of the world experience a seasonal peak in influenza activity, influenza viruses can be isolated yearround. The timing of seasonal peaks in influenza activity in tropical and subtropical countries varies by region, and multiple peaks of activity during the same year have been seen in some areas.
} 
During May 24-September 5, typical seasonal patterns of influenza activity occurred in temperate climate Southern Hemisphere countries. In Australia, influenza activity began to increase in early June, while influenza activity in New Zealand began to increase in mid-July. Activity in both countries remained elevated as of early September. In Australia and New Zealand, influenza B viruses predominated overall, but the proportion of influenza A ( $\mathrm{H} 3 \mathrm{~N} 2)$ viruses increased during July and August. Small numbers of pH1N1 viruses were reported from both countries. In South Africa, influenza activity began to increase in late May, peaked in late June, and decreased in late July. Influenza A (H3N2) and pH1N1 viruses predominated in that country, but influenza $\mathrm{B}$ viruses also were reported. In temperate countries of South America, influenza activity began to increase in June, remained elevated through July, and decreased in August. Influenza A viruses were reported more frequently than influenza $\mathrm{B}$ viruses, and both $\mathrm{pH} 1 \mathrm{~N} 1$ and influenza $\mathrm{A}(\mathrm{H} 3 \mathrm{~N} 2)$ viruses were detected in Chile and Paraguay. Influenza A (H3N2) viruses predominated in Argentina. In temperate climate countries of Europe and North America, influenza activity was low, and small numbers of $\mathrm{pH} 1 \mathrm{~N} 1$, influenza $\mathrm{A}(\mathrm{H} 3 \mathrm{~N} 2)$, and influenza $\mathrm{B}$ viruses were identified.

In countries with tropical influenza seasonality, overall influenza activity remained low, and the predominant virus varied by country. In the Caribbean and Central America, influenza A viruses were more commonly reported, with influenza A (H3N2) viruses predominating in Mexico and El Salvador, while pH1N1 viruses were more frequently reported in Cuba. In tropical South America, influenza A viruses predominated. Influenza $\mathrm{A}(\mathrm{H} 3 \mathrm{~N} 2)$ and $\mathrm{pH} 1 \mathrm{~N} 1$ viruses co-circulated in Colombia and Peru, while influenza A $(\mathrm{H} 3 \mathrm{~N} 2)$ viruses predominated in Brazil and Ecuador; however, influenza $B$ viruses were more frequently reported in Bolivia. In South Asia and Southeast Asia, a decrease in influenza activity was observed during August and September, and influenza A (H3N2) viruses predominated in Cambodia, China, Laos, Philippines, Singapore, Thailand, and Vietnam, with smaller numbers of $\mathrm{pH} 1 \mathrm{~N} 1$ and influenza $\mathrm{B}$ viruses reported. In Indonesia, influenza $\mathrm{B}$ viruses were more frequently reported, but influenza $\mathrm{A}(\mathrm{H} 3 \mathrm{~N} 2)$ and $\mathrm{pH} 1 \mathrm{~N} 1$ viruses also were identified. During May 24-September 5, four laboratory-confirmed human cases of avian influenza A (H5N1) virus infection were reported to WHO from Egypt, and one case of influenza A (H5N6) and five cases of influenza A (H7N9) were identified in China. ${ }^{\dagger \dagger}$

\footnotetext{
††† The list of WHO Disease Outbreak News updates are available at http:// www.who.int/csr/don/archive/year/2015/en.
}

\section{Antigenic and Genetic Characterization of Influenza Viruses}

The components for the 2015-16 Northern Hemisphere influenza vaccines were selected in February 2015 during the twice-yearly WHO-sponsored vaccine consultation meeting to review data generated by GISRS laboratories. The recommended Northern Hemisphere 2015-16 vaccine composition was the same as was recommended for the 2015 Southern Hemisphere and included an A/California/7/2009 (H1N1) pdm09-like virus, an A/Switzerland/9715293/2013 (H3N2)like virus, and a B/Phuket/3073/2013-like (B/Yamagata lineage) virus for trivalent influenza vaccines (3). An additional influenza B virus (B/Brisbane/60/2008-like [B/Victoria lineage]) was recommended for quadrivalent vaccines (3). Influenza viruses used to produce most influenza vaccines in the United States must be grown in eggs per current regulatory requirements. However egg propagation of influenza viruses, and influenza A (H3N2) viruses in particular, can lead to genetic changes that might have antigenic implications. The vaccine viruses selected for the Northern Hemisphere 2015-16 vaccine were representative of most, but not all circulating influenza viruses at that time, and had the fewest and least significant egg-adapted changes.

The WHO Collaborating Center for Surveillance, Epidemiology, and Control of Influenza, located at CDC, receives and characterizes influenza virus isolates from laboratories worldwide. CDC and other collaborating centers routinely use hemagglutination inhibition (HI) assays to antigenically characterize influenza viruses to compare how similar currently circulating influenza viruses are to those included in the influenza vaccine, and to monitor for changes in circulating influenza viruses. Beginning in the 2014-15 season and to date, however, a portion of influenza A (H3N2) viruses did not yield sufficient hemagglutination titers for antigenic characterization by HI. For many of these viruses, CDC performed genetic characterization which provided the genetic group identity of circulating viruses. In this way, antigenic properties of these viruses can be inferred from viruses within the same genetic group that have been characterized antigenically. During May 24-September 5, a total of 199 viruses collected from the United States and worldwide were antigenically and/or genetically characterized by CDC, including 20 influenza A (H1N1)pdm09 viruses, 118 influenza A (H3N2) viruses, and 61 influenza $B$ viruses.

All $20(100 \%)$ influenza A (H1N1)pdm09 viruses (16 international and four U.S.) were antigenically similar to the A/California/7/2009, the influenza A (H1N1)pdm09 
vaccine component. Of the 118 influenza A (H3N2) viruses characterized (31 international and 87 U.S.), all 118 (100\%) were antigenically similar to A/Switzerland/9715293/2013, or belonged to a genetic group for which a majority of antigenically characterized viruses were similar to the A/Switzerland/9715293/2013 vaccine component.

Of the 61 influenza B viruses collected and analyzed (11 international and 50 U.S.), 35 (57\%) belonged to the B/Yamagata lineage, and all 35 (100\%) of these were antigenically similar to the B/Phuket/3073/2013 virus, the influenza B component for both the 2015-16 Northern Hemisphere trivalent and quadrivalent vaccines. The remaining 26 viruses (43\%) belonged to the $\mathrm{B} /$ Victoria lineage and were antigenically similar to the $\mathrm{B} / \mathrm{Brisbane} / 60 / 2008$ virus, the $\mathrm{B} / \mathrm{Victoria}$ lineage component of the 2015-16 Northern Hemisphere quadrivalent influenza vaccine.

Additional viruses have been characterized by the other collaborating centers. That information is presented elsewhere (2).

\section{Antiviral Resistance Profiles of Influenza Virus Isolates}

The WHO Collaborating Center for Surveillance, Epidemiology, and Control of Influenza at CDC tested 169 influenza virus specimens collected during May 24September 5 from the U.S. and worldwide for resistance to the influenza neuraminidase inhibitor antiviral medications; oseltamivir, zanamivir, and peramivir, which are the drugs currently approved for use against seasonal influenza. All 19 (16 international and three U.S.) pH1N1 viruses, 84 (five international and 79 U.S.) influenza A (H3N2) viruses, and 66 (11 international and 55 U.S) influenza B viruses tested were sensitive to all three antiviral medications. High levels of resistance to the adamantanes (amantadine and rimantadine) persist among pH1N1 and influenza A (H3N2) viruses. Adamantane drugs are not recommended for use against influenza at this time.

\section{Discussion}

During May 24-September 5, 2015, pH1N1, influenza A (H3N2), and influenza B viruses co-circulated worldwide. In the United States, low levels of influenza activity were reported, and influenza A viruses were more frequently reported from late June to September. All of the influenza viruses collected from U.S. states and other countries during that time were antigenically and/or genetically characterized as being similar to the influenza vaccine viruses recommended for inclusion in the 2015-16 Northern Hemisphere vaccine. Antigenic and genetic characterization of circulating influenza viruses can give an indication of the influenza vaccine's ability to produce an immune response against circulating influenza viruses, but vaccine effectiveness studies are needed to determine how much protection has been provided by vaccination to the community. Last season, low vaccine effectiveness observed against the predominant influenza $\mathrm{A}(\mathrm{H} 3 \mathrm{~N} 2)$ viruses was consistent with laboratory data indicating that most influenza $\mathrm{A}$ $(\mathrm{H} 3 \mathrm{~N} 2)$ viruses that circulated were antigenically and genetically different (drifted) from the influenza A (H3N2) vaccine component of the 2014-15 Northern Hemisphere influenza vaccines (4). It is not possible to predict which influenza virus will predominate or how severe influenza-related disease activity will be during the 2015-16 season, nor is it possible to say with certainty how effective influenza vaccine will be; however, laboratory analysis of influenza viruses to date suggests that the majority of viruses circulating worldwide in the past few months are similar to $2015-16$ vaccine viruses.

Annual influenza vaccination is the best method for preventing influenza and its potentially severe complications (3). While vaccine effectiveness can vary, vaccination has been shown to reduce influenza illnesses, doctors' visits, influenzarelated hospitalizations, and deaths $(5,6)$. Even during seasons when vaccine effectiveness is reduced, substantial public health impact can still be measured (6-8). In the United States, annual influenza vaccination is recommended for all persons aged $\geq 6$ months who do not have contraindications. Annual influenza vaccination is recommended regardless of whether the vaccine composition has changed because immunity from vaccination might wane after one season. For the 2015-16 influenza season, interim supply projections by manufacturers for the U.S. market range from 171 million and 179 million doses of vaccine. This would to be the largest supply of influenza vaccine distributed in the United States during one season with the exception of the 2009 pandemic.

Multiple influenza vaccines are approved for use and are being distributed during the 2015-16 season, including a quadrivalent live attenuated influenza vaccine (LAIV4), trivalent and quadrivalent inactivated influenza vaccines (IIV3 and IIV4, respectively), a trivalent cell culture-based inactivated influenza vaccine (ccIIV3), a high-dose trivalent inactivated influenza vaccine (hd IIV3), and a recombinant trivalent influenza vaccine (RIV3). One IIV4 formulation also is approved for intradermal administration. Although both LAIV and inactivated influenza vaccine (IIV) have been demonstrated to be effective in children and adults, LAIV is approved for use in persons aged 2 through 49 years with no contraindications 
or precautions ${ }^{\$ \$ \$}$ (3). For the $2015-16$ season, the Advisory Committee on Immunization Practices recommended that healthy children aged 2 through 8 years who have no contraindications or precautions receive either LAIV or IIV, with no preference expressed for either vaccine when one is otherwise appropriate and available (3). This removes the 2014-15 preferential recommendation of LAIV for healthy children aged 2 through 8 years (3). For the 2015-16 season, ACIP recommends that children aged 6 months through 8 years who have previously received $\geq 2$ total doses of trivalent or quadrivalent influenza vaccine at any time before July 1,2015 , require only 1 dose for 2015-16 (3). The 2 previous doses do not need to have been given during the same or consecutive seasons (3). Children in this age group who are being vaccinated for the first time or who have not previously received a total of $\geq 2$ doses require 2 doses of influenza vaccine, administered $\geq 4$ weeks apart (9).

Although vaccination is the best method for preventing and reducing the impact of influenza, antiviral medications are a valuable adjunct. Treatment with influenza antiviral medications is recommended as early as possible for patients with confirmed or suspected influenza (either seasonal influenza or novel influenza virus infection) who have severe, complicated, or progressive illness; who require hospitalization; or who are at high risk for influenza-related complications 99 (10). Antiviral

\$S\$ LAIV should not be used in the following populations: 1) persons aged $<2$ years or $>49$ years; 2 ) those with contraindications listed in the package insert (children aged 2 through 17 years who are receiving aspirin or aspirincontaining products and persons who have experienced severe allergic reactions to the vaccine or any of its components, or to a previous dose of any influenza vaccine); 3) pregnant women; 4) immunosuppressed persons; 5) persons with a history of egg allergy; 6) children aged 2 through 4 years who have asthma or who have had a wheezing episode noted in the medical record within the past 12 months, or for whom parents report that a health care provider stated that the child had wheezing or asthma within the last 12 months; 7) persons who have taken influenza antiviral medications within the previous 48 hours; and 8) persons who care for severely immunosuppressed persons who require a protective environment (such persons should not receive LAIV, or should avoid contact with immunosuppressed persons for 7 days after receipt, given the theoretical risk for transmission of the live attenuated vaccine virus).

999 Persons at high risk include 1 ) children aged $<5$ years (especially those aged $<2$ years); 2) adults aged $\geq 65$ years; 3 ) persons with chronic pulmonary (including asthma), cardiovascular (except hypertension alone), renal, hepatic, hematologic (including sickle cell disease), metabolic disorders (including diabetes mellitus), or neurologic and neurodevelopment conditions (including disorders of the brain, spinal cord, peripheral nerve, and muscle, such as cerebral palsy, epilepsy [seizure disorders], stroke, intellectual disability [mental retardation], moderate to severe developmental delay, muscular dystrophy, or spinal cord injury); 4) persons with immunosuppression, including that caused by medications or by human immunodeficiency virus infection; 5) women who are pregnant or postpartum (within 2 weeks after delivery); 6) persons aged $\leq 18$ years who are receiving long-term aspirin therapy; 7) American Indians/Alaska Natives; 8 ) persons who are morbidly obese (i.e., with a body mass index $\geq 40$ ); and 9) residents of nursing homes and other chronic care facilities.

\section{Summary}

What is already known on this topic?

CDC collects, compiles, and analyzes data on influenza activity year-round in the United States. The influenza season generally begins in the fall and continues through the winter and spring months; however, the timing and severity of disease and the predominant viral strains can vary by geographic location and season.

What is added by this report?

Worldwide, influenza activity during May 24-September 5, 2015, was elevated in the temperate Southern Hemisphere and tropical regions, compared with their levels outside the usual influenza season. In the United States, low levels of seasonal influenza activity were detected.

What are the implications for public health practice?

In the United States, an influenza vaccine is recommended for all persons aged $\geq 6$ months and can reduce the likelihood of becoming ill with influenza and transmitting the virus to others. Annual influenza vaccination is recommended for optimal protection regardless of whether the vaccine composition has changed since the previous season because immunity wanes over time. Although vaccination is the best way to prevent influenza, treatment with influenza antiviral medications can reduce severe outcomes of influenza, especially when initiated as early as possible, in patients with confirmed or suspected influenza who have severe, complicated, or progressive illness; who require hospitalization; or who are at high risk for influenza-related complications.

treatment should not be withheld from high-risk or severely ill patients with suspected influenza infection (10). Treatment is most effective when given early in the illness; providers should not delay treatment until test results become available and should not rely on insensitive assays such as rapid antigen detection influenza diagnostic tests to determine treatment decisions (10).

Influenza surveillance reports for the United States are posted online weekly and are available at http://www.cdc.gov/flu/ weekly. Additional information regarding influenza viruses, influenza surveillance, influenza vaccines, influenza antiviral medications, and novel influenza A virus infections in humans is available at http://www.cdc.gov/flu.

\section{Acknowledgments}

State, county, city, and territorial health departments and public health laboratories; U.S. World Health Organization collaborating laboratories; National Respiratory and Enteric Virus Surveillance System laboratories; U.S. Outpatient Influenza-Like Illness Surveillance Network sites; 122 Cities Mortality Reporting System; World Health Organization FluNet. 
${ }^{1}$ Influenza Division, National Center for Immunization and Respiratory Diseases, CDC.

Corresponding author: Lenee Blanton, lblanton@cdc.gov, 404-639-3747.

\section{References}

1. World Health Organization. Influenza: WHO Collaborating Centers and Essential Regulatory Laboratories. Available at http://www.who.int/ influenza/gisrs_laboratory/collaborating_centres/en.

2. World Health Organization. FluNet. Available at. http://www.who.int/ influenza/gisrs_laboratory/flunet/en.

3. Grohskopf LA, Sokolow LZ, Olsen SJ, Bresee JS, Broder KR, Karron RA. Prevention and control of influenza with vaccines: recommendations of the Advisory Committee on Immunization Practices (ACIP) - United States, 2015-16 influenza season. MMWR Morb Mortal Wkly Rep 2015;64:818-25.

4. CDC. CDC presents updated estimates of flu vaccine effectiveness for the 2014-2015 season. Available at http://www.cdc.gov/flu/news/ updated-vaccine-effectiveness-2014-15.htm.
5. Reed C, Kim IK, Singleton JA, et al. Estimated influenza illnesses and hospitalizations averted by vaccination-United States, 2013-14 influenza season. MMWR Morb Mortal Wkly Rep 2014;63:1151-4.

6. Foppa IM, Cheng PY, Reynolds SD, et al. Deaths averted by influenza vaccination in the U.S. during the seasons 2005/06 through 2013/14. Vaccine 2015;33:3003-9.

7. Kostova D, Reed C, Finelli L, et al. Influenza illness and hospitalizations averted by influenza vaccination in the United States, 2005-2011. PLoS One 2013;8:e66312.

8. Fry AM, Kim IK, Reed C, et al. Modeling the effect of different vaccine effectiveness estimates on the number of vaccine-prevented influenza-associated hospitalizations in older adults. Clin Infect Dis 2014;59:406-9.

9. Neuzil KM, Jackson LA, Nelson J, et al. Immunogenicity and reactogenicity of 1 versus 2 doses of trivalent inactivated influenza vaccine in vaccine-naive 5-8-year-old children. J Infect Dis 2006;194:1032-9.

10. Fiore AE, Fry A, Shay D, Gubareva L, Bresee JS, Uyeki TM. Antiviral agents for the treatment and chemoprophylaxis of influenzarecommendations of the Advisory Committee on Immunization Practices (ACIP). MMWR Recomm Rep 2011;60(No. RR-1):1-24. 


\section{Available Online: Final 2014-15 Influenza Vaccination Coverage Estimates for Selected Local Areas, States, and the United States}

Final 2014-15 influenza season vaccination coverage estimates are available online at FluVaxView (http://www.cdc.gov/ flu/fluvaxview/) as of 10 a.m. Thursday, September 17, 2015. The online information includes estimates of the cumulative percentage of persons vaccinated by the end of each month, from July 2014 through May 2015, for selected local areas, each state, each U.S. Department of Health and Human Services region, and the United States overall.

Analyses were conducted using National Immunization Survey influenza vaccination data for children aged 6 months -17 years and Behavioral Risk Factor Surveillance System influenza vaccination data for adults aged $\geq 18$ years. Estimates are provided by age group and race/ethnicity. These estimates are presented in an interactive report (http://www.cdc.gov/ flu/fluvaxview/interactive.htm) and are complemented by an online summary report (http://www.cdc.gov/flu/fluvaxview/ coverage-1415estimates.htm).

\section{National Fall Prevention Awareness Day - September 23, 2015}

Annually in the United States, 2.5 million persons aged $\geq 65$ years are treated in emergency departments for injuries from falls, resulting in $\$ 34$ billion in direct medical costs (1). Given these costs, the aging U.S. population, and the increasing fall death rates (2), falls have become a major risk to the health of older persons in the United States.

In conjunction with the 2015 White House Conference on Aging, CDC launched the implementation of the STEADI (Stopping Elderly Accidents, Deaths, and Injuries) initiative for healthcare providers. STEADI uses established clinical guidelines and scientifically tested interventions to help providers address their patients' risk for falls, identify modifiable risk factors, and provide effective interventions (3). Free online training with continuing education is available and electronic health record vendors (Epic and GE Centricity) are developing STEADI modules to help incorporate fall prevention into clinical practice. For every 5,000 providers adopting STEADI over a 5-year period, one million additional falls could be avoided, saving an additional $\$ 3.5$ billion in direct medical costs (4).

National Fall Prevention Awareness Day is September 23. As part of the campaign, health care providers are encouraged to do the following:

- Screen patients by asking if they have fallen in the past year, feel unsteady, or worry about falling

- Review patients' medications and stop, switch, or reduce the dose of drugs that increase the risk for falls

- Recommend daily vitamin D with calcium

Additional information is available at http://www.cdc.gov/steadi.

\section{References}

1. CDC. Injury prevention and control: data and statistics (WISQARS). Atlanta, GA: US Department of Health and Human Services, CDC; 2015. Available at http://www.cdc.gov/injury/wisqars.

2. Sheu Y, Chen L, Hedegaard H. QuickStats: death rates from unintentional falls among adults aged $\geq 65$ years, by sex-United States, 2000-2013. MMWR Morb Mortal Wkly Rep 2015;64:450.

3. Stevens JA, Phelan EA. Development of STEADI: a fall prevention resource for health care providers. Health Promot Pract 2013;14:706-14.

4. CDC. STEADI-older adult fall prevention. Atlanta, GA: US Department of Health and Human Services, CDC; 2015. Available at http://www.cdc.gov/steadi. 


\section{National Child Passenger Safety Week - September 13-19, 2015}

This year, National Child Passenger Safety Week is September 13-19. In the United States, motor vehicle-related injuries are a leading cause of death among children (1). In 2013, a total of 638 passenger vehicle occupants aged $0-12$ years died as a result of a crash (2), and more than 127,250 were injured (1). Of the children that died in 2013,38\% were known to be unrestrained (2). To keep child passengers as safe as possible, drivers should properly restrain children aged $<13$ years in age- and size-appropriate restraints in a back seat and follow the American Academy of Pediatrics' child passenger safety recommendations (3).

As part of National Child Passenger Safety Week, September 19 has been designated as National Seat Check Saturday. On this day, drivers with children who ride in car seats or booster seats are encouraged to visit a child safety seat inspection station to have a certified technician inspect their car seat for proper installation and proper use free of charge. Additional information and an inspection station locator are available from CDC at http://www.cdc.gov/motorvehiclesafety/child_passenger_safety and the National Highway Traffic Safety Administration at http://www.nhtsa.gov/Safety/ CPS. Campaign promotional materials in English and Spanish are available at http://www.trafficsafetymarketing.gov/cps.

\section{References}

1. CDC. Web-Based Injury Statistics Query and Reporting System (WISQARS). Available at www.cdc.gov/ncipc/wisqars.

2. National Highway Traffic Safety Administration. Traffic safety facts 2013 data-occupant protection. Available at http://www-nrd.nhtsa.dot.gov/ Pubs/812153.pdf.

3. Durbin DR; Committee on Injury, Violence, and Poison Prevention. Child passenger safety. Pediatrics 2011;127:e1050-66. 


\section{Final 2014 Reports of Nationally Notifiable Infectious Diseases}

The tables listed in this report on pages 1020-1033 summarize finalized data, as of June 30, 2015, from the National Notifiable Diseases Surveillance System (NNDSS) for 2014. These data will be published in more detail in the Summary of Notifiable Diseases, United States, 2014 (1). Because no cases were reported in the United States during 2014, the following diseases do not appear in these early release tables: anthrax; dengue hemorrhagic fever; eastern equine encephalitis, nonneuroinvasive; poliomyelitis, paralytic; poliovirus infection, nonparalytic; severe acute respiratory syndrome-associated coronavirus disease (SARS$\mathrm{CoV}$ ); smallpox; vancomycin-resistant Staphylococcus aureus (VRSA); western equine encephalitis virus disease, neuroinvasive and nonneuroinvasive; and yellow fever.

Policies for reporting NNDSS data to CDC can vary by disease or reporting jurisdiction, depending on case status classification (i.e., confirmed, probable, or suspected). The publication criteria used for the 2014 finalized tables are listed in the "Print Criteria" column of the NNDSS event code list, available at http://wwwn.cdc.gov/nndss/document/ nndss_event_code_list_2014.pdf.
In addition, only cases from reporting jurisdictions where the nationally notifiable disease is reportable are published. The NNDSS website is updated annually to include the latest national surveillance case definitions approved by the Council of State and Territorial Epidemiologists (CSTE) for classifying and enumerating cases of nationally notifiable infectious diseases.

Population estimates are from the National Center for Health Statistics postcensal estimates of resident population of the United States for July 1, 2013-July 1, 2014, by year, county, single-year of age ( $0-\geq 85$ years), bridged race (white, black or African American, American Indian or Alaska Native, Asian, or Pacific Islander), Hispanic origin (not Hispanic or Latino, Hispanic or Latino), and sex (Vintage 2014), prepared under a collaborative arrangement with the U.S. Census Bureau. Population estimates for states as of June 25, 2015 are available at http://www.cdc.gov/nchs/nvss/bridged_race/data_ documentation.htm\#vintage2014. Population estimates for territories are 2014 estimates from the U.S. Census Bureau (2).

\section{References}

1. CDC. Summary of notifiable diseases, United States, 2014. MMWR Morb Mortal Wkly Rep. In press.

2. US Census Bureau. International data base. Washington, DC: US Census Bureau; 2015. Available at http://www.census.gov/population/ international/data/idb/informationGateway.php. 
TABLE 2. Reported cases of notifiable diseases, ${ }^{*}$ by geographic division and area - United States, 2014

\begin{tabular}{|c|c|c|c|c|c|c|c|c|c|c|}
\hline \multirow[b]{3}{*}{ Area } & \multirow{3}{*}{$\begin{array}{c}\text { Total resident } \\
\text { population } \\
\text { (in thousands) }\end{array}$} & \multicolumn{9}{|c|}{ Arboviruses ${ }^{\dagger}$} \\
\hline & & \multicolumn{2}{|c|}{ California serogroup $\S$} & \multirow{2}{*}{$\begin{array}{c}\begin{array}{c}\text { Eastern equine } \\
\text { encephalitis }\end{array} \\
\begin{array}{c}\text { Neuro- } \\
\text { invasive }\end{array}\end{array}$} & \multicolumn{2}{|c|}{ Powassan } & \multicolumn{2}{|c|}{ St. Louis encephalitis } & \multicolumn{2}{|c|}{ West Nile } \\
\hline & & $\begin{array}{c}\text { Neuro- } \\
\text { invasive }\end{array}$ & $\begin{array}{c}\text { Nonneuro- } \\
\text { invasive }\end{array}$ & & $\begin{array}{c}\text { Neuro- } \\
\text { invasive }\end{array}$ & $\begin{array}{c}\text { Nonneuro- } \\
\text { invasive }\end{array}$ & $\begin{array}{c}\text { Neuro- } \\
\text { invasive }\end{array}$ & $\begin{array}{c}\text { Nonneuro- } \\
\text { invasive }\end{array}$ & $\begin{array}{c}\text { Neuro- } \\
\text { invasive }\end{array}$ & $\begin{array}{c}\text { Nonneuro- } \\
\text { invasive }\end{array}$ \\
\hline United States & 318,856 & 85 & 11 & 8 & 7 & 1 & 6 & 4 & 1,347 & 858 \\
\hline New England & 14,681 & 2 & - & 4 & 4 & - & - & - & 8 & 4 \\
\hline Connecticut & 3,597 & - & - & - & - & - & - & - & 3 & 3 \\
\hline Maine & 1,330 & - & - & 1 & - & - & - & - & - & - \\
\hline Massachusetts & 6,745 & 2 & - & - & 4 & - & - & - & 5 & 1 \\
\hline New Hampshire & 1,327 & - & - & 3 & - & - & - & - & - & - \\
\hline Rhode Island & 1,055 & - & - & - & - & - & - & - & - & - \\
\hline Vermont & 627 & - & - & - & - & & - & - & - & - \\
\hline Mid. Atlantic & 41,471 & - & - & 2 & 1 & 1 & - & - & 36 & 11 \\
\hline New Jersey & 8,938 & - & - & - & 1 & - & - & - & 6 & 2 \\
\hline New York (Upstate) & 11,255 & - & - & 2 & - & 1 & - & - & 7 & 4 \\
\hline New York City & 8,491 & - & - & - & - & - & - & - & 12 & 3 \\
\hline Pennsylvania & 12,787 & - & - & - & - & - & - & - & 11 & 2 \\
\hline E.N. Central & 46,740 & 37 & 6 & 1 & 2 & - & - & - & 59 & 13 \\
\hline Illinois & 12,881 & - & 1 & - & - & - & - & - & 36 & 8 \\
\hline Indiana & 6,597 & 2 & - & - & - & - & - & - & 9 & 1 \\
\hline Michigan & 9,910 & - & - & 1 & - & - & - & - & 1 & - \\
\hline Ohio & 11,594 & 30 & 1 & - & - & - & - & - & 10 & 1 \\
\hline Wisconsin & 5,758 & 5 & 4 & - & 2 & - & - & - & 3 & 3 \\
\hline W.N.Central & 21,006 & 6 & 2 & - & - & - & - & - & 104 & 221 \\
\hline lowa & 3,107 & - & - & - & - & - & - & - & 5 & 10 \\
\hline Kansas & 2,904 & - & - & - & - & - & - & - & 18 & 36 \\
\hline Minnesota & 5,457 & 6 & 2 & - & - & - & - & - & 6 & 15 \\
\hline Missouri & 6,064 & - & - & - & - & - & - & - & 10 & 3 \\
\hline Nebraska & 1,882 & - & - & - & - & - & - & - & 41 & 101 \\
\hline North Dakota & 739 & - & - & - & - & - & - & - & 12 & 11 \\
\hline South Dakota & 853 & - & - & - & - & - & - & - & 12 & 45 \\
\hline S. Atlantic & 62,513 & 28 & 2 & - & - & - & 2 & - & 38 & 11 \\
\hline Delaware & 936 & - & - & - & - & - & - & - & - & - \\
\hline District of Columbia & 659 & - & - & - & - & - & - & - & 1 & 2 \\
\hline Florida & 19,893 & 1 & - & - & - & - & 2 & - & 12 & 5 \\
\hline Georgia & 10,097 & 1 & 1 & - & - & - & - & - & 11 & 2 \\
\hline Maryland & 5,976 & - & - & - & - & - & - & - & 6 & - \\
\hline North Carolina & 9,944 & 23 & - & - & - & - & - & - & - & - \\
\hline South Carolina & 4,832 & - & - & - & - & - & - & - & 3 & - \\
\hline Virginia & 8,326 & 2 & - & - & - & - & - & - & 5 & 2 \\
\hline West Virginia & 1,850 & 1 & 1 & - & - & - & - & - & - & - \\
\hline E.S. Central & 18,805 & 12 & 1 & 1 & - & - & 3 & - & 38 & 24 \\
\hline Alabama & 4,849 & - & - & 1 & - & - & 1 & - & - & 2 \\
\hline Kentucky & 4,413 & - & - & - & - & - & - & - & - & 1 \\
\hline Mississippi & 2,994 & - & 1 & - & - & - & 2 & - & 26 & 17 \\
\hline Tennessee & 6,549 & 12 & - & - & - & - & - & - & 12 & 4 \\
\hline W.S. Central & 38,451 & - & - & - & - & - & 1 & 3 & 332 & 201 \\
\hline Arkansas & 2,966 & - & - & - & - & - & - & - & 9 & 2 \\
\hline Louisiana & 4,650 & - & - & - & - & - & - & - & 61 & 64 \\
\hline Oklahoma & 3,878 & - & - & - & - & - & - & - & 9 & 9 \\
\hline Texas & 26,957 & - & - & - & - & - & 1 & 3 & 253 & 126 \\
\hline Mountain & 23,197 & - & - & - & - & - & - & 1 & 157 & 126 \\
\hline Arizona & 6,731 & - & - & - & - & - & - & 1 & 80 & 27 \\
\hline Colorado & 5,356 & - & - & - & - & - & - & - & 46 & 72 \\
\hline Idaho & 1,634 & - & - & - & - & - & - & - & 6 & 13 \\
\hline Montana & 1,024 & - & - & - & - & - & - & - & 2 & 3 \\
\hline Nevada & 2,839 & - & - & - & - & - & - & - & 3 & - \\
\hline New Mexico & 2,086 & - & - & - & - & - & - & - & 19 & 5 \\
\hline Utah & 2,943 & - & - & - & - & - & - & - & 1 & 1 \\
\hline Wyoming & 584 & - & - & - & - & - & - & - & - & 5 \\
\hline Pacific & 51,992 & - & - & - & - & - & - & - & 575 & 247 \\
\hline Alaska & 737 & - & - & - & - & - & - & - & - & - \\
\hline California & 38,803 & - & - & - & - & - & - & - & 561 & 240 \\
\hline Hawaii & 1,420 & - & - & - & - & - & - & - & - & 1 \\
\hline Oregon & 3,970 & - & - & - & - & - & - & - & 7 & 1 \\
\hline Washington & 7,062 & - & - & - & - & - & - & - & 7 & 5 \\
\hline Territories & & & & & & & & & & \\
\hline American Samoa & 55 & - & - & - & - & - & - & - & - & - \\
\hline C.N.M.I. & 51 & - & - & - & - & - & - & - & - & - \\
\hline Guam & 161 & - & - & - & - & - & - & - & - & - \\
\hline Puerto Rico & 3,621 & - & - & - & - & - & - & - & - & - \\
\hline U.S. Virgin Islands & 104 & - & - & - & - & - & - & - & - & - \\
\hline
\end{tabular}

N: Not Reportable U: Unavailable -: No reported cases C.N.M.I.: Commonwealth of the Northern Mariana Islands.

* No cases of anthrax; dengue hemorrhagic fever; eastern equine encephalitis, non-neuroinvasive; poliomyelitis, paralytic; poliovirus infection, nonparalytic; severe acute respiratory syndromeassociated coronavirus disease (SARS-CoV); smallpox; vancomycin-resistant Staphylococcus aureus (VRSA); western equine encephalitis virus disease, neuroinvasive and nonneuroinvasive; or yellow fever were reported in the United States during 2014.

† Totals reported to the Division of Vector-Borne Diseases (DVBD), National Center for Emerging and Zoonotic Infectious Diseases (NCEZID) (ArboNET Surveillance), as of July 1, 2015.

$\S$ California serogroup viral diseases for 2014 include LaCrosse virus, Jamestown Canyon virus and California serogroup viruses not specified. 
TABLE 2. (Continued) Reported cases of notifiable diseases, * by geographic division and area - United States, 2014

\begin{tabular}{|c|c|c|c|c|c|c|c|c|}
\hline \multirow[b]{2}{*}{ Area } & \multicolumn{3}{|c|}{ Babesiosis } & \multicolumn{4}{|c|}{ Botulism } & \multirow[b]{2}{*}{ Brucellosis } \\
\hline & Total & Confirmed & Probable & Total & Foodborne & Infant & Other ${ }^{\dagger}$ & \\
\hline United States & 1,759 & 1,472 & 287 & 161 & 15 & 127 & 19 & 92 \\
\hline New England & 1,007 & 902 & 105 & 1 & - & 1 & - & 3 \\
\hline Connecticut & 212 & 173 & 39 & - & - & - & - & - \\
\hline Maine & 42 & 34 & 8 & - & - & - & - & - \\
\hline Massachusetts & 537 & 510 & 27 & - & - & - & - & 3 \\
\hline New Hampshire & 41 & 36 & 5 & - & - & - & - & - \\
\hline Rhode Island & 172 & 148 & 24 & - & - & - & - & - \\
\hline Vermont & 3 & 1 & 2 & 1 & - & 1 & - & - \\
\hline Mid. Atlantic & 640 & 498 & 142 & 26 & 2 & 24 & - & 2 \\
\hline New Jersey & 169 & 133 & 36 & 10 & - & 10 & - & 1 \\
\hline New York (Upstate) & 421 & 319 & 102 & 5 & 2 & 3 & - & - \\
\hline New York City & 50 & 46 & 4 & 2 & - & 2 & - & 1 \\
\hline Pennsylvania & $\mathrm{N}$ & $\mathrm{N}$ & $\mathrm{N}$ & 9 & - & 9 & - & - \\
\hline E.N. Central & 46 & 31 & 15 & 8 & 4 & 4 & - & 12 \\
\hline Illinois & 1 & 1 & - & 1 & 1 & - & - & 4 \\
\hline Indiana & - & - & - & 1 & 1 & - & - & - \\
\hline Michigan & 2 & 1 & 1 & 1 & - & 1 & - & 2 \\
\hline Ohio & $\mathrm{N}$ & $\mathrm{N}$ & $\mathrm{N}$ & 5 & 2 & 3 & - & 1 \\
\hline Wisconsin & 43 & 29 & 14 & - & - & - & - & 5 \\
\hline W.N.Central & 50 & 32 & 18 & 4 & - & 4 & - & 4 \\
\hline lowa & $\mathrm{N}$ & $\mathrm{N}$ & $\mathrm{N}$ & - & - & - & $\mathrm{N}$ & - \\
\hline Kansas & $\mathrm{N}$ & $\mathrm{N}$ & $\mathrm{N}$ & - & - & - & - & 2 \\
\hline Minnesota & 49 & 31 & 18 & 1 & - & 1 & - & 1 \\
\hline Missouri & $\mathrm{N}$ & $\mathrm{N}$ & $\mathrm{N}$ & 3 & - & 3 & - & - \\
\hline Nebraska & - & - & - & - & - & - & - & 1 \\
\hline North Dakota & - & - & - & - & - & - & - & - \\
\hline South Dakota & 1 & 1 & - & - & - & - & - & - \\
\hline S. Atlantic & 6 & 3 & 3 & 18 & - & 17 & 1 & 19 \\
\hline Delaware & 1 & 1 & - & 4 & - & 4 & - & - \\
\hline District of Columbia & $\mathrm{N}$ & $\mathrm{N}$ & $\mathrm{N}$ & 1 & - & 1 & - & 2 \\
\hline Florida & $\mathrm{N}$ & $\mathrm{N}$ & $\mathrm{N}$ & - & - & - & - & 3 \\
\hline Georgia & $\mathrm{N}$ & $\mathrm{N}$ & $\mathrm{N}$ & 2 & - & 2 & - & 7 \\
\hline Maryland & 2 & - & 2 & 10 & - & 9 & 1 & - \\
\hline North Carolina & $\mathrm{N}$ & $\mathrm{N}$ & $\mathrm{N}$ & - & - & - & - & 2 \\
\hline South Carolina & 3 & 2 & 1 & - & - & - & - & 1 \\
\hline Virginia & $\mathrm{N}$ & - & - & 1 & - & 1 & - & 1 \\
\hline West Virginia & - & $\mathrm{N}$ & $\mathrm{N}$ & - & - & - & - & 3 \\
\hline E.S. Central & 1 & - & 1 & 2 & - & 2 & - & 2 \\
\hline Alabama & 1 & - & 1 & - & - & - & - & - \\
\hline Kentucky & $\mathrm{N}$ & $\mathrm{N}$ & $\mathrm{N}$ & 1 & - & 1 & - & 1 \\
\hline Mississippi & $\mathrm{N}$ & $\mathrm{N}$ & $\mathrm{N}$ & - & - & - & - & - \\
\hline Tennessee & - & - & - & 1 & - & 1 & - & 1 \\
\hline W.S. Central & 1 & 1 & - & 11 & - & 8 & 3 & 16 \\
\hline Arkansas & - & $\mathrm{N}$ & $\mathrm{N}$ & 3 & - & 1 & 2 & - \\
\hline Louisiana & - & - & - & - & - & - & - & - \\
\hline Oklahoma & $\mathrm{N}$ & - & - & - & - & - & - & 1 \\
\hline Texas & 1 & 1 & - & 8 & - & 7 & 1 & 15 \\
\hline Mountain & - & - & - & 17 & 1 & 15 & 1 & 9 \\
\hline Arizona & - & $\mathrm{N}$ & $N$ & 2 & - & 1 & 1 & 6 \\
\hline Colorado & $\mathrm{N}$ & $\mathrm{N}$ & $\mathrm{N}$ & 6 & 1 & 5 & - & 3 \\
\hline Idaho & $\mathrm{N}$ & $\mathrm{N}$ & $\mathrm{N}$ & - & - & - & - & - \\
\hline Montana & - & - & - & 1 & - & 1 & - & - \\
\hline Nevada & $\mathrm{N}$ & $\mathrm{N}$ & $\mathrm{N}$ & 1 & - & 1 & - & - \\
\hline New Mexico & $\mathrm{N}$ & $\mathrm{N}$ & $\mathrm{N}$ & 1 & - & 1 & - & - \\
\hline Utah & - & - & - & 6 & - & 6 & - & - \\
\hline Wyoming & - & - & - & - & - & - & - & - \\
\hline Pacific & 8 & 5 & 3 & 74 & 8 & 52 & 14 & 25 \\
\hline Alaska & $\mathrm{N}$ & $\mathrm{N}$ & $\mathrm{N}$ & 7 & 7 & - & - & - \\
\hline California & 3 & 2 & 1 & 63 & - & 49 & 14 & 20 \\
\hline Hawaii & $\mathrm{N}$ & $\mathrm{N}$ & $\mathrm{N}$ & - & - & - & - & 1 \\
\hline Oregon & 1 & - & 1 & 1 & 1 & - & - & 1 \\
\hline Washington & 4 & 3 & 1 & 3 & - & 3 & - & 3 \\
\hline Territories & & & & & & & & \\
\hline American Samoa & u & u & $\mathrm{u}$ & - & - & - & - & - \\
\hline C.N.M.I. & - & - & - & - & - & - & - & - \\
\hline Guam & - & - & - & - & - & - & - & - \\
\hline Puerto Rico & $\mathrm{N}$ & $\mathrm{N}$ & $\mathrm{N}$ & - & - & - & - & - \\
\hline U.S. Virgin Islands & $\mathrm{N}$ & $\mathrm{N}$ & $\mathrm{N}$ & - & - & - & - & - \\
\hline
\end{tabular}

N: Not Reportable U: Unavailable -: No reported cases C.N.M.I.: Commonwealth of the Northern Mariana Islands.

* No cases of anthrax; dengue hemorrhagic fever; eastern equine encephalitis, non-neuroinvasive; poliomyelitis, paralytic; poliovirus infection, nonparalytic; severe acute respiratory syndromeassociated coronavirus disease (SARS-CoV); smallpox; vancomycin-resistant Staphylococcus aureus (VRSA); western equine encephalitis virus disease, neuroinvasive and nonneuroinvasive; or yellow fever were reported in the United States during 2014.

† Includes cases reported as wound and unspecified botulism. 
TABLE 2. (Continued) Reported cases of notifiable diseases, * by geographic division and area - United States, 2014

\begin{tabular}{|c|c|c|c|c|c|c|c|c|}
\hline \multirow[b]{2}{*}{ Area } & \multirow[b]{2}{*}{ Chancroid $^{\dagger}$} & \multirow{2}{*}{$\begin{array}{l}\text { Chlamydia } \\
\text { trachomatis } \\
\text { infection }^{\dagger}\end{array}$} & \multirow[b]{2}{*}{ Cholera } & \multirow[b]{2}{*}{ Coccidioidomycosis } & \multicolumn{3}{|c|}{ Cryptosporidiosis } & \multirow[b]{2}{*}{ Cyclosporiasis } \\
\hline & & & & & Total & Confirmed & Probable & \\
\hline United States & 6 & $1,441,789$ & 5 & 8,232 & 8,682 & 5,565 & 3,117 & 388 \\
\hline $\begin{array}{l}\text { New England } \\
\text { Connecticut } \\
\text { Maine } \\
\text { Massachusetts } \\
\text { New Hampshire } \\
\text { Rhode Island } \\
\text { Vermont }\end{array}$ & $\begin{array}{l}1 \\
- \\
- \\
- \\
-\end{array}$ & $\begin{array}{r}48,355 \\
13,382 \\
3,530 \\
21,271 \\
3,586 \\
4,349 \\
2,237\end{array}$ & $\begin{array}{l}1 \\
- \\
-1 \\
- \\
-\end{array}$ & $\begin{array}{l}5 \\
\mathrm{~N} \\
\mathrm{~N} \\
\\
3 \\
2 \\
\mathrm{~N}\end{array}$ & $\begin{array}{r}318 \\
45 \\
51 \\
139 \\
40 \\
16 \\
27\end{array}$ & $\begin{array}{r}282 \\
45 \\
34 \\
139 \\
23 \\
16 \\
25\end{array}$ & $\frac{\frac{36}{17}}{\frac{17}{2}}$ & $\begin{array}{r}26 \\
8 \\
\mathrm{~N} \\
18 \\
- \\
- \\
-\end{array}$ \\
\hline $\begin{array}{l}\text { Mid. Atlantic } \\
\text { New Jersey } \\
\text { New York (Upstate) } \\
\text { New York City } \\
\text { Pennsylvania }\end{array}$ & $\begin{array}{l}- \\
z \\
= \\
-\end{array}$ & $\begin{array}{r}179,254 \\
29,904 \\
38,845 \\
59,969 \\
50,536\end{array}$ & $\begin{array}{l}- \\
- \\
- \\
-\end{array}$ & $\begin{array}{l}- \\
N \\
N \\
N \\
N\end{array}$ & $\begin{array}{r}785 \\
77 \\
237 \\
102 \\
369\end{array}$ & $\begin{array}{r}609 \\
77 \\
230 \\
102 \\
200\end{array}$ & $\frac{176}{\frac{7}{7}}$ & $\begin{array}{r}53 \\
16 \\
14 \\
23 \\
\mathrm{~N}\end{array}$ \\
\hline $\begin{array}{l}\text { E.N. Central } \\
\text { Illinois } \\
\text { Indiana } \\
\text { Michigan } \\
\text { Ohio } \\
\text { Wisconsin }\end{array}$ & $\begin{array}{l}- \\
= \\
= \\
-\end{array}$ & $\begin{array}{r}217,323 \\
66,536 \\
28,519 \\
44,256 \\
54,858 \\
23,154\end{array}$ & $\begin{array}{l}- \\
\overline{-} \\
\overline{-} \\
-\end{array}$ & $\begin{array}{r}55 \\
N \\
N \\
33 \\
16 \\
6\end{array}$ & $\begin{array}{r}1,451 \\
158 \\
185 \\
239 \\
324 \\
545\end{array}$ & $\begin{array}{r}1,044 \\
79 \\
96 \\
215 \\
109 \\
545\end{array}$ & $\begin{array}{r}407 \\
79 \\
89 \\
24 \\
215 \\
-\end{array}$ & $\begin{array}{r}26 \\
14 \\
2 \\
8 \\
1 \\
1\end{array}$ \\
\hline $\begin{array}{l}\text { W.N. Central } \\
\text { lowa } \\
\text { Kansas } \\
\text { Minnesota } \\
\text { Missouri } \\
\text { Nebraska } \\
\text { North Dakota } \\
\text { South Dakota }\end{array}$ & $\begin{array}{l}- \\
= \\
= \\
= \\
=\end{array}$ & \begin{tabular}{r|}
85,924 \\
11,804 \\
11,116 \\
19,907 \\
27,981 \\
7,499 \\
3,451 \\
4,166
\end{tabular} & $\begin{array}{l}1 \\
- \\
-1 \\
- \\
- \\
-\end{array}$ & $\begin{array}{r}118 \\
\mathrm{~N} \\
\mathrm{~N} \\
90 \\
19 \\
4 \\
5 \\
\mathrm{~N}\end{array}$ & $\begin{array}{r}1,248 \\
264 \\
67 \\
338 \\
167 \\
111 \\
148 \\
153\end{array}$ & $\begin{array}{r}666 \\
61 \\
22 \\
244 \\
81 \\
87 \\
143 \\
28\end{array}$ & $\begin{array}{r}582 \\
203 \\
45 \\
94 \\
86 \\
24 \\
5 \\
125\end{array}$ & $\begin{array}{l}10 \\
-1 \\
5 \\
1 \\
3 \\
\mathrm{~N} \\
-\end{array}$ \\
\hline $\begin{array}{l}\text { S. Atlantic } \\
\text { Delaware } \\
\text { District of Columbia } \\
\text { Florida } \\
\text { Georgia } \\
\text { Maryland } \\
\text { North Carolina } \\
\text { South Carolina } \\
\text { Virginia } \\
\text { West Virginia }\end{array}$ & $\begin{array}{l}- \\
= \\
= \\
= \\
= \\
= \\
-\end{array}$ & $\begin{array}{r}289,330 \\
4,473 \\
5,293 \\
84,194 \\
51,945 \\
27,424 \\
47,147 \\
28,087 \\
36,048 \\
4,719 \\
\end{array}$ & $\begin{array}{l}2 \\
\overline{-} \\
2 \\
= \\
= \\
= \\
=\end{array}$ & $\begin{array}{r}11 \\
- \\
1 \\
N \\
N \\
10 \\
N \\
N \\
N \\
N\end{array}$ & $\begin{array}{r}2,627 \\
8 \\
5 \\
1,905 \\
240 \\
79 \\
166 \\
63 \\
152 \\
9\end{array}$ & $\begin{array}{r}1,488 \\
6 \\
5 \\
1,031 \\
240 \\
47 \\
85 \\
41 \\
32 \\
1\end{array}$ & $\begin{array}{r}1,139 \\
2 \\
- \\
874 \\
32 \\
81 \\
22 \\
120 \\
8\end{array}$ & $\begin{array}{r}60 \\
- \\
- \\
33 \\
6 \\
4 \\
4 \\
8 \\
4 \\
1\end{array}$ \\
\hline $\begin{array}{l}\text { E.S. Central } \\
\text { Alabama } \\
\text { Kentucky } \\
\text { Mississippi } \\
\text { Tennessee }\end{array}$ & $\begin{array}{l}- \\
- \\
- \\
-\end{array}$ & $\begin{array}{l}97,072 \\
29,010 \\
17,664 \\
19,605 \\
30,793\end{array}$ & $\begin{array}{l}- \\
- \\
- \\
-\end{array}$ & $\begin{array}{l}- \\
N \\
N \\
N \\
N\end{array}$ & $\begin{array}{r}411 \\
147 \\
80 \\
66 \\
118\end{array}$ & $\begin{array}{r}282 \\
67 \\
50 \\
66 \\
99\end{array}$ & $\begin{array}{r}129 \\
80 \\
30 \\
19\end{array}$ & $\begin{array}{r}1 \\
N \\
N \\
N \\
1\end{array}$ \\
\hline $\begin{array}{l}\text { W.S. Central } \\
\text { Arkansas } \\
\text { Louisiana } \\
\text { Oklahoma } \\
\text { Texas }\end{array}$ & $\begin{array}{l}\frac{1}{-} \\
\frac{-}{1}\end{array}$ & $\begin{array}{r}196,441 \\
15,605 \\
28,955 \\
20,662 \\
131,219\end{array}$ & $\begin{array}{l}- \\
\overline{-} \\
\overline{-}\end{array}$ & $\begin{array}{l}3 \\
- \\
3 \\
N \\
N\end{array}$ & $\begin{array}{r}804 \\
56 \\
244 \\
88 \\
416\end{array}$ & $\begin{array}{r}436 \\
55 \\
107 \\
23 \\
251\end{array}$ & $\begin{array}{r}368 \\
1 \\
137 \\
65 \\
165\end{array}$ & $\begin{array}{r}201 \\
1 \\
\bar{N} \\
200\end{array}$ \\
\hline $\begin{array}{l}\text { Mountain } \\
\text { Arizona } \\
\text { Colorado } \\
\text { Idaho } \\
\text { Montana } \\
\text { Nevada } \\
\text { New Mexico } \\
\text { Utah } \\
\text { Wyoming }\end{array}$ & $\begin{array}{l}- \\
= \\
= \\
= \\
= \\
=\end{array}$ & \begin{tabular}{r|}
97,489 \\
32,397 \\
21,863 \\
5,442 \\
4,193 \\
11,841 \\
11,558 \\
8,223 \\
1,972 \\
\end{tabular} & $\begin{array}{l}1 \\
-1 \\
= \\
= \\
= \\
-\end{array}$ & $\begin{array}{r}5,792 \\
5,624 \\
\mathrm{~N} \\
\mathrm{~N} \\
10 \\
70 \\
40 \\
46 \\
2\end{array}$ & $\begin{array}{r}487 \\
46 \\
75 \\
100 \\
66 \\
16 \\
86 \\
70 \\
28\end{array}$ & $\begin{array}{r}361 \\
33 \\
52 \\
87 \\
57 \\
10 \\
80 \\
16 \\
26\end{array}$ & $\begin{array}{r}126 \\
13 \\
23 \\
13 \\
9 \\
6 \\
6 \\
54 \\
2\end{array}$ & $\begin{array}{r}6 \\
2 \\
1 \\
N \\
2 \\
N \\
-1 \\
-\end{array}$ \\
\hline $\begin{array}{l}\text { Pacific } \\
\text { Alaska } \\
\text { California } \\
\text { Hawaii } \\
\text { Oregon } \\
\text { Washington }\end{array}$ & $\begin{array}{l}4 \\
- \\
- \\
- \\
-\end{array}$ & \begin{tabular}{r|}
230,601 \\
5,789 \\
176,308 \\
6,419 \\
15,508 \\
26,577 \\
\end{tabular} & $\begin{array}{l}- \\
= \\
= \\
= \\
-\end{array}$ & $\begin{array}{r}2,248 \\
N \\
2,243 \\
N \\
5 \\
N\end{array}$ & $\begin{array}{r}551 \\
4 \\
357 \\
3 \\
112 \\
75 \\
\end{array}$ & $\begin{array}{r}397 \\
3 \\
346 \\
3 \\
10 \\
35\end{array}$ & $\begin{array}{r}154 \\
1 \\
11 \\
-102 \\
40\end{array}$ & $\begin{array}{r}\frac{5}{2} \\
-1 \\
2\end{array}$ \\
\hline $\begin{array}{l}\text { Territories } \\
\text { American Samoa } \\
\text { C.N.M.I. } \\
\text { Guam } \\
\text { Puerto Rico } \\
\text { U.S. Virgin Islands } \\
\end{array}$ & $\begin{array}{l}- \\
\overline{-} \\
- \\
\end{array}$ & $\begin{array}{r}- \\
839 \\
4,899 \\
791 \\
\end{array}$ & $\begin{array}{l}- \\
- \\
- \\
-\end{array}$ & $\begin{array}{l}\frac{\mathrm{N}}{-} \\
\frac{\mathrm{N}}{-} \\
\end{array}$ & $\begin{array}{l}\mathrm{N} \\
- \\
- \\
-\end{array}$ & $\begin{array}{l}\mathrm{N} \\
- \\
- \\
-\end{array}$ & $\begin{array}{l}\frac{\mathrm{N}}{-} \\
- \\
-\end{array}$ & $\begin{array}{l}\frac{N}{-} \\
- \\
-\end{array}$ \\
\hline
\end{tabular}

N: Not Reportable U: Unavailable - -: No reported cases C.N.M.I.: Commonwealth of the Northern Mariana Islands.

* No cases of anthrax; dengue hemorrhagic fever; eastern equine encephalitis, non-neuroinvasive; poliomyelitis, paralytic; poliovirus infection, nonparalytic; severe acute respiratory syndrome-

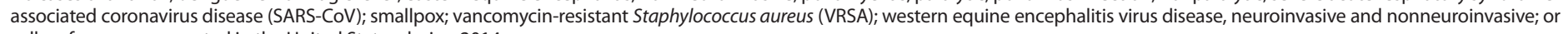
yellow fever were reported in the United States during 2014.

† Totals reported to the Division of STD Prevention, NCHHSTP, as of June 10, 2015. 
TABLE 2. (Continued) Reported cases of notifiable diseases, ${ }^{*}$ by geographic division and area - United States, 2014

\begin{tabular}{|c|c|c|c|c|c|c|}
\hline \multirow[b]{2}{*}{ Area } & \multirow[b]{2}{*}{$\begin{array}{c}\text { Dengue Virus Infection } \\
\text { Dengue Fever }\end{array}$} & \multirow[b]{2}{*}{ Diphtheria } & \multicolumn{4}{|c|}{ Ehrlichiosis/Anaplasmosis } \\
\hline & & & $\begin{array}{c}\text { Anaplasma } \\
\text { phagocytophilum }\end{array}$ & Ehrlichia chaffeensis & Ehrlichia ewingii & Undetermined \\
\hline United States & 677 & 1 & 2,800 & 1,475 & 17 & 196 \\
\hline New England & 35 & - & 1,182 & 60 & - & 10 \\
\hline Connecticut & 3 & - & 75 & - & - & - \\
\hline Maine & 1 & - & 191 & 8 & - & 6 \\
\hline Massachusetts & 17 & - & 621 & 20 & - & 1 \\
\hline New Hampshire & 5 & - & 131 & 7 & - & 2 \\
\hline Rhode Island & 5 & - & 97 & 24 & - & - \\
\hline Vermont & 4 & - & 67 & 1 & - & 1 \\
\hline Mid. Atlantic & 160 & - & 547 & 177 & - & 26 \\
\hline New Jersey & 84 & - & 69 & 54 & - & 10 \\
\hline New York (Upstate) & 28 & - & 421 & 109 & - & 11 \\
\hline New York City & 42 & - & 32 & 9 & - & - \\
\hline Pennsylvania & 6 & - & 25 & 5 & - & 5 \\
\hline E.N. Central & 34 & 1 & 507 & 62 & - & 96 \\
\hline Illinois & 7 & - & 18 & 47 & - & - \\
\hline Indiana & 5 & - & - & - & - & 49 \\
\hline Michigan & 5 & - & 4 & 3 & - & - \\
\hline Ohio & 9 & 1 & 1 & 4 & - & 1 \\
\hline Wisconsin & 8 & - & 484 & 8 & - & 46 \\
\hline W.N. Central & 10 & - & 483 & 386 & 12 & 39 \\
\hline lowa & 4 & - & $\mathrm{N}$ & $\mathrm{N}$ & $\mathrm{N}$ & $\mathrm{N}$ \\
\hline Kansas & 1 & - & 4 & 46 & 2 & 3 \\
\hline Minnesota & 3 & - & 448 & 5 & 1 & 17 \\
\hline Missouri & 2 & - & 24 & 328 & 9 & 19 \\
\hline Nebraska & - & - & 1 & 6 & - & - \\
\hline North Dakota & - & - & 6 & 1 & - & - \\
\hline South Dakota & - & - & - & - & - & - \\
\hline S. Atlantic & 125 & - & 41 & 299 & 3 & 10 \\
\hline Delaware & 1 & - & 2 & 22 & - & - \\
\hline District of Columbia & 2 & - & - & - & - & 1 \\
\hline Florida & 84 & - & 7 & 29 & - & - \\
\hline Georgia & 4 & - & 1 & 14 & - & 1 \\
\hline Maryland & 8 & - & 2 & 38 & 1 & - \\
\hline North Carolina & 8 & - & 12 & 73 & - & - \\
\hline South Carolina & 2 & - & - & 8 & - & - \\
\hline $\begin{array}{l}\text { Virginia } \\
\text { Vin }\end{array}$ & 15 & - & 15 & 112 & 2 & 8 \\
\hline West Virginia & 1 & - & 2 & 3 & - & - \\
\hline E.S. Central & 8 & - & 11 & 163 & 1 & 12 \\
\hline Alabama & 3 & - & 7 & 10 & - & 2 \\
\hline Kentucky & 1 & - & - & 62 & - & - \\
\hline Mississippi & 2 & - & 1 & 4 & - & - \\
\hline Tennessee & 2 & - & 3 & 87 & 1 & 10 \\
\hline W.S. Central & 41 & - & 24 & 328 & 1 & - \\
\hline Arkansas & 4 & - & 15 & 236 & 1 & - \\
\hline Louisiana & 3 & - & 2 & 3 & - & - \\
\hline Oklahoma & - & - & 4 & 77 & - & - \\
\hline Texas & 34 & - & 3 & 12 & - & - \\
\hline Mountain & 113 & - & - & - & - & 1 \\
\hline Arizona & 97 & - & - & - & - & 1 \\
\hline Colorado & 10 & - & $\mathrm{N}$ & $\mathrm{N}$ & $\mathrm{N}$ & $\mathrm{N}$ \\
\hline Idaho & 1 & - & $\mathrm{N}$ & $\mathrm{N}$ & $\mathrm{N}$ & $\mathrm{N}$ \\
\hline Montana & 2 & - & - & - & - & - \\
\hline Nevada & 3 & - & - & - & - & - \\
\hline New Mexico & - & - & $\mathrm{N}$ & $\mathrm{N}$ & $\mathrm{N}$ & $\mathrm{N}$ \\
\hline Utah & - & - & - & - & - & - \\
\hline Wyoming & - & - & - & - & - & - \\
\hline Pacific & 151 & - & 5 & - & - & 2 \\
\hline Alaska & 4 & - & $\mathrm{N}$ & $\mathrm{N}$ & $\mathrm{N}$ & $\mathrm{N}$ \\
\hline California & 128 & - & 5 & - & - & 2 \\
\hline Hawaii & 10 & - & $\mathrm{N}$ & $\mathrm{N}$ & $\mathrm{N}$ & - \\
\hline Oregon & - & - & - & - & - & $\mathrm{N}$ \\
\hline Washington & 9 & - & - & - & - & - \\
\hline Territories & & & & & & \\
\hline American Samoa & - & - & $\mathrm{N}$ & $\mathrm{N}$ & $\mathrm{N}$ & $\mathrm{N}$ \\
\hline C.N.M.I. & - & - & - & - & - & - \\
\hline Guam & - & - & $\mathrm{N}$ & $\mathrm{N}$ & $\mathrm{N}$ & $\mathrm{N}$ \\
\hline Puerto Rico & 524 & - & $\mathrm{N}$ & $\mathrm{N}$ & $\mathrm{N}$ & $\mathrm{N}$ \\
\hline U.S. Virgin Islands & 19 & - & - & - & - & - \\
\hline
\end{tabular}

N: Not Reportable U: Unavailable -: No reported cases C.N.M.I.: Commonwealth of the Northern Mariana Islands.

* No cases of anthrax; dengue hemorrhagic fever; eastern equine encephalitis, non-neuroinvasive; poliomyelitis, paralytic; poliovirus infection, nonparalytic; severe acute respiratory syndromeassociated coronavirus disease (SARS-CoV); smallpox; vancomycin-resistant Staphylococcus aureus (VRSA); western equine encephalitis virus disease, neuroinvasive and nonneuroinvasive; or yellow fever were reported in the United States during 2014.

† Total number of reported laboratory-positive dengue cases including all confirmed cases [by anti-dengue virus (DENV) molecular diagnostic methods or sero-conversion of anti-DENV $\mathrm{lgM}]$ and all probable cases (by a single, positive anti-DENV IgM). Totals reported to the Division of Vector-Borne Diseases (DVBD), National Center for Emerging and Zoonotic Infectious Diseases (NCEZID) (ArboNET Surveillance), as of July 1, 2015. 
TABLE 2. (Continued) Reported cases of notifiable diseases, ${ }^{*}$ by geographic division and area - United States, 2014

\begin{tabular}{|c|c|c|c|c|c|c|c|c|}
\hline \multirow[b]{3}{*}{ Area } & \multirow[b]{3}{*}{ Giardiasis } & \multirow[b]{3}{*}{ Gonorrhea $^{\dagger}$} & \multicolumn{5}{|c|}{ Haemophilus influenzae, invasive disease } & \multirow{3}{*}{$\begin{array}{c}\text { Hansen's disease } \\
\text { (leprosy) }\end{array}$} \\
\hline & & & \multirow{2}{*}{$\begin{array}{c}\begin{array}{c}\text { All ages, } \\
\text { serotypes }\end{array} \\
\end{array}$} & \multicolumn{4}{|c|}{ Age $<5$ years } & \\
\hline & & & & Serotype b & Not typeable & Nonserotype b & Not tested & \\
\hline United States & 14,554 & 350,062 & 3,541 & 40 & 128 & 100 & 204 & 88 \\
\hline $\begin{array}{r}\text { New England } \\
\text { Connecticut }\end{array}$ & $\begin{array}{r}1,361 \\
219\end{array}$ & $\begin{array}{l}7,287 \\
2333\end{array}$ & $\begin{array}{r}240 \\
60\end{array}$ & 2 & 8 & $\begin{array}{r}10 \\
9\end{array}$ & 2 & 3 \\
\hline Maine & 154 & 237 & 21 & 1 & 2 & - & - & $\mathrm{N}$ \\
\hline Massachusetts & 709 & 3,817 & 104 & 1 & 4 & - & 1 & 3 \\
\hline New Hampshire & 97 & 226 & 24 & - & 1 & - & 1 & - \\
\hline Rhode Island & 45 & 590 & 16 & - & 1 & 1 & - & - \\
\hline Vermont & 137 & 84 & 15 & - & - & - & - & $\mathrm{N}$ \\
\hline Mid. Atlantic & 2,931 & 40,104 & 598 & 9 & 15 & 5 & 28 & 10 \\
\hline New Jersey & 384 & 6,636 & 149 & - & - & - & 14 & - \\
\hline New York (Upstate) & 951 & 6,616 & 148 & 3 & 5 & 1 & - & $\mathrm{N}$ \\
\hline New York City & 874 & 14,142 & 120 & - & - & - & 12 & 10 \\
\hline Pennsylvania & 722 & 12,710 & 181 & 6 & 10 & 4 & 2 & - \\
\hline E.N. Central & 1,562 & 53,262 & 589 & 7 & 33 & 18 & 13 & 4 \\
\hline Illinois & $\mathrm{N}$ & 15,970 & 164 & - & 4 & 5 & 5 & - \\
\hline Indiana & 167 & 7,289 & 102 & 2 & 5 & 3 & 1 & - \\
\hline Michigan & 506 & 9,688 & 106 & 4 & 5 & - & 5 & 1 \\
\hline Ohio & 385 & 16,237 & 128 & - & 15 & 4 & 2 & 2 \\
\hline Wisconsin & 504 & 4,078 & 89 & 1 & 4 & 6 & - & 1 \\
\hline W.N.Central & 1,501 & 18,714 & 304 & 2 & 1 & 7 & 35 & 2 \\
\hline lowa & 205 & 1,641 & 4 & 1 & - & - & - & - \\
\hline Kansas & 104 & 2,568 & 43 & 1 & 1 & 4 & 4 & - \\
\hline Minnesota & 662 & 4,073 & 127 & - & - & - & 18 & - \\
\hline Missouri & 228 & 7,387 & 97 & - & - & - & 8 & 2 \\
\hline Nebraska & 131 & 1,459 & 25 & - & - & 2 & 4 & - \\
\hline North Dakota & 39 & 694 & 8 & - & - & 1 & 1 & $\mathrm{~N}$ \\
\hline South Dakota & 132 & 892 & - & - & - & - & - & - \\
\hline S. Atlantic & 2,663 & 75,743 & 854 & 4 & 14 & 9 & 63 & 13 \\
\hline Delaware & 24 & 1,279 & 16 & - & - & - & 4 & - \\
\hline District of Columbia & 78 & 1,883 & 10 & - & - & - & 2 & - \\
\hline Florida & 1,165 & 20,944 & 259 & - & - & - & 32 & 10 \\
\hline Georgia & 656 & 13,770 & 138 & 1 & 5 & 4 & 8 & 1 \\
\hline Maryland & 268 & 6,108 & 85 & 1 & 1 & 2 & - & 1 \\
\hline North Carolina & $\mathrm{N}$ & 14,415 & 146 & - & - & - & 16 & - \\
\hline South Carolina & 150 & 8,253 & 63 & 1 & 1 & - & - & - \\
\hline Virginia & 256 & 8,250 & 89 & - & 7 & 1 & 1 & 1 \\
\hline West Virginia & 66 & 841 & 48 & 1 & - & 2 & - & $\mathrm{N}$ \\
\hline E.S. Central & 182 & 24,854 & 239 & - & 18 & 12 & 10 & 5 \\
\hline Alabama & 182 & 7,677 & 65 & - & 7 & 3 & 3 & - \\
\hline Kentucky & $\mathrm{N}$ & 4,353 & 37 & - & 1 & 1 & 6 & 1 \\
\hline Mississippi & $\mathrm{N}$ & 5,625 & 36 & - & - & 5 & - & 4 \\
\hline Tennessee & $\mathrm{N}$ & 7,199 & 101 & - & 10 & 3 & 1 & - \\
\hline W.S.Central & 393 & 55,000 & 204 & 7 & 9 & 2 & 6 & 27 \\
\hline Arkansas & 113 & 4,539 & 50 & - & 4 & - & - & 7 \\
\hline Louisiana & 280 & 9,002 & 46 & - & - & - & 6 & 1 \\
\hline Oklahoma & $\mathrm{N}$ & 6,137 & 96 & 1 & 5 & 2 & - & $\mathrm{N}$ \\
\hline Texas & $\mathrm{N}$ & 35,322 & 12 & 6 & $\mathrm{~N}$ & $\mathrm{~N}$ & $\mathrm{~N}$ & 19 \\
\hline Mountain & 1,111 & 18,788 & 330 & 5 & 25 & 26 & 2 & 4 \\
\hline Arizona & 119 & 7,750 & 101 & - & 8 & 12 & - & - \\
\hline Colorado & 332 & 3,170 & 66 & - & 4 & 2 & 2 & 1 \\
\hline Idaho & 154 & 443 & 18 & - & - & - & - & - \\
\hline Montana & 89 & 434 & 14 & 1 & - & 1 & - & - \\
\hline Nevada & 65 & 3,188 & 17 & - & 2 & 1 & - & 1 \\
\hline New Mexico & 101 & 2,246 & 49 & 2 & 4 & 6 & - & - \\
\hline Utah & 225 & 1,441 & 59 & 2 & 7 & 3 & - & 2 \\
\hline Wyoming & 26 & 116 & 6 & - & - & 1 & - & - \\
\hline Pacific & 2,850 & 56,310 & 183 & 4 & 5 & 11 & 45 & 20 \\
\hline Alaska & 89 & 1,341 & 25 & - & 4 & 2 & 1 & - \\
\hline California & 1,852 & 45,408 & 42 & - & - & - & 35 & 6 \\
\hline Hawaii & 43 & 1,020 & 23 & - & - & - & 6 & 14 \\
\hline Oregon & 351 & 2,320 & 84 & - & 1 & 7 & - & $\mathrm{N}$ \\
\hline Washington & 515 & 6,221 & 9 & 4 & - & 2 & 3 & $\mathrm{~N}$ \\
\hline Territories & & & & & & & & \\
\hline American Samoa & - & - & - & - & - & - & - & - \\
\hline C.N.M.I. & - & - & - & - & - & - & - & - \\
\hline Guam & 1 & 99 & - & - & - & - & - & 13 \\
\hline Puerto Rico & 31 & 454 & 3 & - & - & - & 1 & 2 \\
\hline U.S. Virgin Islands & - & 84 & $\mathrm{~N}$ & $\mathrm{~N}$ & $\mathrm{~N}$ & $\mathrm{~N}$ & $\mathrm{~N}$ & - \\
\hline
\end{tabular}

N: Not Reportable U: Unavailable -: No reported cases C.N.M.I.: Commonwealth of the Northern Mariana Islands.

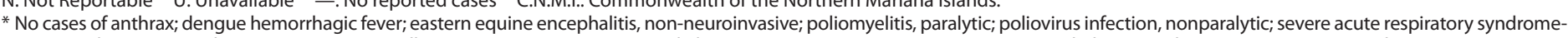

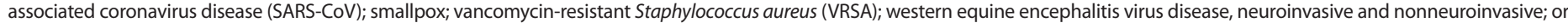
yellow fever were reported in the United States during 2014.

+ Totals reported to the Division of STD Prevention, NCHHSTP, as of June 10, 2015. 
TABLE 2. (Continued) Reported cases of notifiable diseases, * by geographic division and area - United States, 2014

\begin{tabular}{|c|c|c|c|c|c|c|c|c|}
\hline \multirow[b]{2}{*}{ Area } & \multirow{2}{*}{$\begin{array}{l}\text { Hantavirus } \\
\text { pulmonary } \\
\text { syndrome }\end{array}$} & \multirow{2}{*}{$\begin{array}{c}\text { Hemolytic uremic } \\
\text { syndrome, } \\
\text { post-diarrheal }\end{array}$} & \multicolumn{6}{|c|}{ Hepatitis } \\
\hline & & & $\begin{array}{c}\text { A } \\
\text { acute }\end{array}$ & $\begin{array}{c}\text { B } \\
\text { acute }\end{array}$ & $\begin{array}{c}\text { B } \\
\text { chronic }^{\dagger}\end{array}$ & $\begin{array}{c}\text { B } \\
\text { perinatal infection }\end{array}$ & $\begin{array}{c}\mathrm{C} \\
\text { acute }\end{array}$ & $\begin{array}{c}\mathrm{C} \\
\text { chronic }^{\dagger}\end{array}$ \\
\hline United States & 32 & 250 & 1,239 & 2,953 & 12,400 & 47 & 2,204 & 162,863 \\
\hline $\begin{array}{l}\text { New England } \\
\text { Connecticut } \\
\text { Maine } \\
\text { Massachusetts } \\
\text { New Hampshire } \\
\text { Rhode Island } \\
\text { Vermont }\end{array}$ & $\begin{array}{l}\bar{N} \\
- \\
- \\
-\end{array}$ & $\begin{array}{r}11 \\
4 \\
1 \\
6 \\
- \\
-\end{array}$ & $\begin{array}{r}88 \\
23 \\
8 \\
43 \\
5 \\
8 \\
1\end{array}$ & $\begin{array}{r}59 \\
9 \\
12 \\
30 \\
4 \\
\cup \\
4\end{array}$ & $\begin{array}{r}411 \\
72 \\
44 \\
233 \\
28 \\
U \\
34\end{array}$ & $\begin{array}{l}\frac{1}{-} \\
-1 \\
- \\
-\end{array}$ & $\begin{array}{r}272 \\
9 \\
31 \\
228 \\
\mathrm{~N} \\
\mathrm{U} \\
4\end{array}$ & $\begin{array}{r}11,227 \\
3,263 \\
1,423 \\
5,639 \\
\mathrm{~N} \\
\mathrm{U} \\
902\end{array}$ \\
\hline $\begin{array}{l}\text { Mid. Atlantic } \\
\text { New Jersey } \\
\text { New York (Upstate) } \\
\text { New York City } \\
\text { Pennsylvania }\end{array}$ & $\begin{array}{l}- \\
- \\
- \\
-\end{array}$ & $\begin{array}{r}7 \\
3 \\
3 \\
1 \\
-\end{array}$ & $\begin{array}{r}191 \\
59 \\
38 \\
46 \\
48\end{array}$ & $\begin{array}{r}240 \\
77 \\
38 \\
57 \\
68\end{array}$ & $\begin{array}{r}3,669 \\
487 \\
496 \\
1,759 \\
927\end{array}$ & $\begin{array}{r}11 \\
1 \\
6 \\
4\end{array}$ & $\begin{array}{r}308 \\
113 \\
113 \\
13 \\
69\end{array}$ & $\begin{array}{r}33,947 \\
7,765 \\
8,448 \\
7,339 \\
10,395 \\
\end{array}$ \\
\hline $\begin{array}{l}\text { E.N. Central } \\
\text { Illinois } \\
\text { Indiana } \\
\text { Michigan } \\
\text { Ohio } \\
\text { Wisconsin }\end{array}$ & $\begin{array}{l}- \\
- \\
- \\
-\end{array}$ & $\begin{array}{r}33 \\
4 \\
7 \\
6 \\
9 \\
7\end{array}$ & $\begin{array}{r}186 \\
82 \\
20 \\
45 \\
32 \\
7\end{array}$ & $\begin{array}{r}578 \\
58 \\
126 \\
50 \\
171 \\
173\end{array}$ & $\begin{array}{r}1,662 \\
972 \\
U \\
475 \\
214 \\
1\end{array}$ & $\begin{array}{c}5 \\
- \\
- \\
2 \\
2 \\
1\end{array}$ & $\begin{array}{r}381 \\
27 \\
122 \\
78 \\
105 \\
49\end{array}$ & $\begin{array}{r}32,104 \\
8,777 \\
U \\
7,572 \\
15,755 \\
-\end{array}$ \\
\hline $\begin{array}{l}\text { W.N. Central } \\
\text { lowa } \\
\text { Kansas } \\
\text { Minnesota } \\
\text { Missouri } \\
\text { Nebraska } \\
\text { North Dakota } \\
\text { South Dakota }\end{array}$ & $\begin{array}{l}4 \\
2 \\
- \\
- \\
- \\
2 \\
-\end{array}$ & $\begin{array}{r}34 \\
6 \\
10 \\
10 \\
6 \\
1 \\
-1 \\
1\end{array}$ & $\begin{array}{r}79 \\
12 \\
7 \\
19 \\
20 \\
9 \\
9 \\
3\end{array}$ & $\begin{array}{r}78 \\
9 \\
11 \\
16 \\
31 \\
8 \\
-3\end{array}$ & $\begin{array}{r}1,013 \\
66 \\
116 \\
197 \\
431 \\
110 \\
83 \\
10\end{array}$ & $\begin{array}{l}2 \\
- \\
- \\
2 \\
- \\
-\end{array}$ & $\begin{array}{r}76 \\
U \\
28 \\
40 \\
6 \\
2 \\
-\end{array}$ & $\begin{array}{r}12,033 \\
- \\
1,560 \\
1,899 \\
6,278 \\
926 \\
848 \\
522\end{array}$ \\
\hline $\begin{array}{l}\text { S. Atlantic } \\
\text { Delaware } \\
\text { District of Columbia } \\
\text { Florida } \\
\text { Georgia } \\
\text { Maryland } \\
\text { North Carolina } \\
\text { South Carolina } \\
\text { Virginia } \\
\text { West Virginia }\end{array}$ & $\begin{array}{l}- \\
= \\
= \\
= \\
= \\
= \\
=\end{array}$ & $\begin{array}{l}31 \\
- \\
7 \\
7 \\
6 \\
4 \\
1 \\
6 \\
-\end{array}$ & $\begin{array}{r}225 \\
1 \\
U \\
90 \\
24 \\
27 \\
38 \\
6 \\
27 \\
12\end{array}$ & $\begin{array}{r}848 \\
8 \\
U \\
313 \\
103 \\
40 \\
100 \\
37 \\
61 \\
186\end{array}$ & $\begin{array}{r}2,874 \\
88 \\
U \\
1,137 \\
N \\
N \\
498 \\
447 \\
145 \\
341 \\
218\end{array}$ & $\begin{array}{r}4 \\
\bar{u} \\
1 \\
- \\
-\frac{2}{1} \\
-1\end{array}$ & $\begin{array}{r}423 \\
U \\
U \\
93 \\
57 \\
42 \\
111 \\
4 \\
54 \\
62\end{array}$ & $\begin{array}{r}49,338 \\
U \\
U \\
22,253 \\
4,237 \\
7,041 \\
N \\
3,586 \\
5,590 \\
6,631\end{array}$ \\
\hline $\begin{array}{l}\text { E.S. Central } \\
\text { Alabama } \\
\text { Kentucky } \\
\text { Mississippi } \\
\text { Tennessee }\end{array}$ & $\frac{\bar{N}}{\bar{N}}$ & $\begin{array}{r}21 \\
1 \\
4 \\
2 \\
14\end{array}$ & $\begin{array}{r}49 \\
15 \\
19 \\
3 \\
12\end{array}$ & $\begin{array}{r}561 \\
117 \\
164 \\
48 \\
232\end{array}$ & $\begin{array}{r}625 \\
N \\
N \\
N \\
625\end{array}$ & $\begin{array}{c}2 \\
\overline{-} \\
\bar{N} \\
2\end{array}$ & $\begin{array}{r}334 \\
35 \\
176 \\
U \\
123\end{array}$ & $\begin{array}{l}-\overline{-} \\
\frac{\mathrm{N}}{\mathrm{N}}\end{array}$ \\
\hline $\begin{array}{l}\text { W.S. Central } \\
\text { Arkansas } \\
\text { Louisiana } \\
\text { Oklahoma } \\
\text { Texas }\end{array}$ & $\begin{array}{c}6 \\
- \\
- \\
1 \\
5\end{array}$ & $\begin{array}{r}37 \\
8 \\
2 \\
21 \\
6\end{array}$ & $\begin{array}{r}148 \\
2 \\
5 \\
17 \\
124\end{array}$ & $\begin{array}{r}294 \\
28 \\
87 \\
57 \\
122\end{array}$ & $\begin{array}{r}211 \\
N \\
125 \\
86 \\
N\end{array}$ & $\begin{array}{r}5 \\
-1 \\
1 \\
3\end{array}$ & $\begin{array}{r}127 \\
13 \\
22 \\
45 \\
47\end{array}$ & $\begin{array}{r}2,657 \\
\mathrm{~N} \\
2,116 \\
541 \\
\mathrm{~N}\end{array}$ \\
\hline $\begin{array}{l}\text { Mountain } \\
\text { Arizona } \\
\text { Colorado } \\
\text { Idaho } \\
\text { Montana } \\
\text { Nevada } \\
\text { New Mexico } \\
\text { Utah } \\
\text { Wyoming }\end{array}$ & $\begin{array}{r}19 \\
5 \\
4 \\
-1 \\
-1 \\
6 \\
2 \\
1\end{array}$ & $\begin{array}{r}30 \\
-6 \\
10 \\
5 \\
1 \\
-8 \\
-\end{array}$ & $\begin{array}{r}86 \\
29 \\
23 \\
7 \\
5 \\
5 \\
8 \\
8 \\
1\end{array}$ & $\begin{array}{r}100 \\
31 \\
29 \\
6 \\
21 \\
2 \\
11 \\
U\end{array}$ & $\begin{array}{r}449 \\
98 \\
144 \\
51 \\
26 \\
\mathrm{~N} \\
50 \\
34 \\
46\end{array}$ & $\begin{array}{l}- \\
= \\
= \\
= \\
= \\
= \\
-\end{array}$ & $\begin{array}{r}112 \\
U \\
33 \\
6 \\
13 \\
6 \\
16 \\
38 \\
U\end{array}$ & $\begin{array}{r}10,299 \\
U \\
3,644 \\
932 \\
1,413 \\
N \\
2,316 \\
1,492 \\
502\end{array}$ \\
\hline $\begin{array}{l}\text { Pacific } \\
\text { Alaska } \\
\text { California } \\
\text { Hawaii } \\
\text { Oregon } \\
\text { Washington }\end{array}$ & $\begin{array}{l}\frac{3}{1} \\
\frac{1}{1} \\
1\end{array}$ & $\begin{array}{r}46 \\
\frac{-}{38} \\
2 \\
6 \\
-\end{array}$ & $\begin{array}{r}187 \\
1 \\
142 \\
5 \\
13 \\
26\end{array}$ & $\begin{array}{r}195 \\
3 \\
110 \\
6 \\
32 \\
44\end{array}$ & $\begin{array}{r}1,486 \\
N \\
1,114 \\
182 \\
97 \\
93\end{array}$ & $\begin{array}{l}\frac{17}{14} \\
\frac{N}{3}\end{array}$ & $\begin{array}{r}171 \\
N \\
73 \\
1 \\
15 \\
82\end{array}$ & $\begin{array}{r}11,258 \\
- \\
1,317 \\
11 \\
5,002 \\
4,928\end{array}$ \\
\hline $\begin{array}{l}\text { Territories } \\
\text { American Samoa } \\
\text { C.N.M.I. } \\
\text { Guam } \\
\text { Puerto Rico } \\
\text { U.S. Virgin Islands } \\
\end{array}$ & $\begin{array}{l}\frac{N}{N} \\
- \\
-\end{array}$ & $\begin{array}{l}\mathrm{N} \\
\overline{-} \\
\mathrm{N} \\
\mathrm{N}\end{array}$ & $\begin{array}{r}- \\
5 \\
8 \\
- \\
\end{array}$ & $\begin{array}{r}- \\
9 \\
19 \\
- \\
\end{array}$ & $\begin{array}{r}\mathrm{N} \\
47 \\
5 \\
-\end{array}$ & $\begin{array}{l}- \\
- \\
- \\
-\end{array}$ & $\begin{array}{r}- \\
- \\
5 \\
\mathrm{~N} \\
-\end{array}$ & $\begin{array}{r}- \\
63 \\
558 \\
-\end{array}$ \\
\hline
\end{tabular}

N: Not Reportable U: Unavailable - $\quad$ : No reported cases C.N.M.I.: Commonwealth of the Northern Mariana Islands.

${ }^{*}$ No cases of anthrax; dengue hemorrhagic fever; eastern equine encephalitis, non-neuroinvasive; poliomyelitis, paralytic; poliovirus infection, nonparalytic; severe acute respiratory syndromeassociated coronavirus disease (SARS-CoV); smallpox; vancomycin-resistant Staphylococcus aureus (VRSA); western equine encephalitis virus disease, neuroinvasive and nonneuroinvasive; or yellow fever were reported in the United States during 2014.

${ }^{+}$Reported cases of chronic hepatitis B and chronic hepatitis C may not reflect unique case reports and may include both confirmed and probable case reports. 
TABLE 2. (Continued) Reported cases of notifiable diseases, ${ }^{*}$ by geographic division and area - United States, 2014

\begin{tabular}{|c|c|c|c|c|c|c|c|}
\hline \multirow[b]{2}{*}{ Area } & \multirow[b]{2}{*}{ HIV diagnoses } & \multirow{2}{*}{$\begin{array}{c}\text { Influenza- } \\
\text { associated pediatric } \\
\text { mortality }{ }^{\dagger}\end{array}$} & \multicolumn{2}{|c|}{ Invasive Pneumococcal disease ${ }^{\S}$} & \multirow[b]{2}{*}{ Legionellosis } & \multirow[b]{2}{*}{ Leptospirosis } & \multirow[b]{2}{*}{ Listeriosis } \\
\hline & & & All Ages & Age $<5$ years & & & \\
\hline United States & 35,606 & 141 & 15,356 & 1,065 & 5,166 & 38 & 769 \\
\hline $\begin{array}{l}\text { New England } \\
\text { Connecticut } \\
\text { Maine } \\
\text { Massachusetts } \\
\text { New Hampshire } \\
\text { Rhode Island } \\
\text { Vermont }\end{array}$ & $\begin{array}{r}887 \\
248 \\
40 \\
474 \\
29 \\
82 \\
14\end{array}$ & $\begin{array}{l}\frac{3}{1} \\
2 \\
- \\
-\end{array}$ & $\begin{array}{r}1,136 \\
241 \\
137 \\
531 \\
98 \\
73 \\
56\end{array}$ & $\begin{array}{r}51 \\
9 \\
6 \\
27 \\
4 \\
4 \\
1\end{array}$ & $\begin{array}{r}270 \\
60 \\
19 \\
144 \\
12 \\
28 \\
7\end{array}$ & $\begin{array}{r}1 \\
\mathrm{~N} \\
1 \\
\mathrm{~N} \\
- \\
-\end{array}$ & $\begin{array}{r}57 \\
15 \\
8 \\
21 \\
2 \\
10 \\
1\end{array}$ \\
\hline $\begin{array}{l}\text { Mid. Atlantic } \\
\text { New Jersey } \\
\text { New York (Upstate) } \\
\text { New York City } \\
\text { Pennsylvania }\end{array}$ & $\begin{array}{r}5,315 \\
1,029 \\
910 \\
2,282 \\
1,094\end{array}$ & $\begin{array}{r}16 \\
6 \\
1 \\
6 \\
3\end{array}$ & $\begin{array}{r}2,009 \\
519 \\
842 \\
648 \\
\mathrm{~N}\end{array}$ & $\begin{array}{r}116 \\
34 \\
48 \\
34 \\
\mathrm{~N}\end{array}$ & $\begin{array}{r}1,173 \\
199 \\
422 \\
228 \\
324\end{array}$ & $\begin{array}{l}1 \\
\frac{-}{1} \\
-\end{array}$ & $\begin{array}{r}136 \\
17 \\
36 \\
37 \\
46\end{array}$ \\
\hline $\begin{array}{l}\text { E.N.Central } \\
\text { Illinois } \\
\text { Indiana } \\
\text { Michigan } \\
\text { Ohio } \\
\text { Wisconsin }\end{array}$ & $\begin{array}{r}3,449 \\
1,171 \\
431 \\
703 \\
932 \\
212\end{array}$ & $\begin{array}{r}10 \\
3 \\
-2 \\
2 \\
3\end{array}$ & $\begin{array}{r}2,600 \\
N \\
624 \\
614 \\
936 \\
426\end{array}$ & $\begin{array}{r}128 \\
32 \\
34 \\
45 \\
17\end{array}$ & $\begin{array}{r}1,108 \\
249 \\
129 \\
229 \\
406 \\
95\end{array}$ & $\begin{array}{r}4 \\
-1 \\
1 \\
2 \\
-\end{array}$ & $\begin{array}{r}100 \\
30 \\
8 \\
20 \\
30 \\
12\end{array}$ \\
\hline $\begin{array}{l}\text { W.N. Central } \\
\text { lowa } \\
\text { Kansas } \\
\text { Minnesota } \\
\text { Missouri } \\
\text { Nebraska } \\
\text { North Dakota } \\
\text { South Dakota }\end{array}$ & $\begin{array}{r}1,053 \\
98 \\
112 \\
245 \\
468 \\
81 \\
24 \\
25\end{array}$ & $\begin{array}{r}10 \\
1 \\
3 \\
5 \\
-1 \\
- \\
-\end{array}$ & $\begin{array}{r}954 \\
\mathrm{~N} \\
136 \\
487 \\
\mathrm{~N} \\
153 \\
88 \\
90\end{array}$ & $\begin{array}{r}83 \\
N \\
N \\
41 \\
23 \\
14 \\
5 \\
N\end{array}$ & $\begin{array}{r}254 \\
33 \\
19 \\
59 \\
106 \\
23 \\
4 \\
10\end{array}$ & $\begin{array}{c}\frac{1}{\mathrm{~N}} \\
\frac{1}{1} \\
\frac{\mathrm{N}}{\mathrm{N}}\end{array}$ & $\begin{array}{r}46 \\
7 \\
6 \\
17 \\
11 \\
4 \\
1 \\
-\end{array}$ \\
\hline $\begin{array}{l}\text { S. Atlantic } \\
\text { Delaware } \\
\text { District of Columbia } \\
\text { Florida } \\
\text { Georgia } \\
\text { Maryland } \\
\text { North Carolina } \\
\text { South Carolina } \\
\text { Virginia } \\
\text { West Virginia }\end{array}$ & $\begin{array}{r}10,895 \\
105 \\
242 \\
5,257 \\
1,401 \\
778 \\
1,378 \\
741 \\
912 \\
81\end{array}$ & $\begin{array}{l}26 \\
- \\
6 \\
1 \\
1 \\
8 \\
2 \\
6 \\
2\end{array}$ & $\begin{array}{r}2,944 \\
41 \\
71 \\
792 \\
925 \\
428 \\
\mathrm{~N} \\
421 \\
19 \\
247\end{array}$ & $\begin{array}{r}241 \\
1 \\
2 \\
89 \\
62 \\
34 \\
\mathrm{~N} \\
23 \\
19 \\
11\end{array}$ & $\begin{array}{r}959 \\
20 \\
13 \\
280 \\
93 \\
144 \\
187 \\
45 \\
129 \\
48\end{array}$ & $\begin{array}{l}- \\
= \\
= \\
= \\
= \\
= \\
=\end{array}$ & $\begin{array}{r}153 \\
1 \\
1 \\
49 \\
15 \\
13 \\
30 \\
10 \\
25 \\
9\end{array}$ \\
\hline $\begin{array}{l}\text { E.S. Central } \\
\text { Alabama } \\
\text { Kentucky } \\
\text { Mississippi } \\
\text { Tennessee }\end{array}$ & $\begin{array}{r}1,944 \\
517 \\
235 \\
463 \\
729\end{array}$ & $\begin{array}{r}9 \\
-1 \\
1 \\
7\end{array}$ & $\begin{array}{r}1,430 \\
213 \\
189 \\
261 \\
767\end{array}$ & $\begin{array}{r}101 \\
17 \\
12 \\
23 \\
49\end{array}$ & $\begin{array}{r}352 \\
63 \\
95 \\
33 \\
161\end{array}$ & $\begin{array}{l}1 \\
1 \\
N \\
N \\
N\end{array}$ & $\begin{array}{r}34 \\
9 \\
3 \\
6 \\
16\end{array}$ \\
\hline $\begin{array}{l}\text { W.S.Central } \\
\text { Arkansas } \\
\text { Louisiana } \\
\text { Oklahoma } \\
\text { Texas }\end{array}$ & $\begin{array}{r}5,649 \\
283 \\
1,400 \\
276 \\
3,690\end{array}$ & $\begin{array}{r}34 \\
2 \\
6 \\
2 \\
24\end{array}$ & $\begin{array}{r}2,205 \\
290 \\
353 \\
N \\
1,562\end{array}$ & $\begin{array}{r}208 \\
26 \\
27 \\
26 \\
129\end{array}$ & $\begin{array}{r}394 \\
38 \\
64 \\
36 \\
256\end{array}$ & $\begin{array}{l}\bar{N} \\
\overline{-} \\
\bar{N}\end{array}$ & $\begin{array}{r}34 \\
4 \\
9 \\
2 \\
19\end{array}$ \\
\hline $\begin{array}{l}\text { Mountain } \\
\text { Arizona } \\
\text { Colorado } \\
\text { Idaho } \\
\text { Montana } \\
\text { Nevada } \\
\text { New Mexico } \\
\text { Utah } \\
\text { Wyoming }\end{array}$ & $\begin{array}{r}1,651 \\
705 \\
361 \\
12 \\
15 \\
388 \\
124 \\
37 \\
9\end{array}$ & $\begin{array}{r}10 \\
3 \\
1 \\
- \\
- \\
3 \\
1 \\
2 \\
-\end{array}$ & $\begin{array}{r}1,902 \\
724 \\
471 \\
\mathrm{~N} \\
40 \\
139 \\
299 \\
204 \\
25\end{array}$ & $\begin{array}{r}116 \\
38 \\
21 \\
7 \\
2 \\
6 \\
14 \\
25 \\
3\end{array}$ & $\begin{array}{r}208 \\
59 \\
65 \\
17 \\
4 \\
25 \\
8 \\
28 \\
2\end{array}$ & $\begin{array}{l}2 \\
1 \\
\mathrm{~N} \\
- \\
- \\
- \\
-1 \\
-\end{array}$ & $\begin{array}{r}50 \\
14 \\
10 \\
3 \\
1 \\
4 \\
9 \\
9 \\
-\end{array}$ \\
\hline $\begin{array}{l}\text { Pacific } \\
\text { Alaska } \\
\text { California } \\
\text { Hawaii } \\
\text { Oregon } \\
\text { Washington } \\
\end{array}$ & $\begin{array}{r}4,763 \\
41 \\
3,988 \\
82 \\
215 \\
437 \\
\end{array}$ & $\begin{array}{l}23 \\
\frac{2}{22} \\
-1 \\
-\end{array}$ & $\begin{array}{r}176 \\
87 \\
\mathrm{~N} \\
89 \\
\mathrm{~N} \\
\mathrm{~N}\end{array}$ & $\begin{array}{r}21 \\
10 \\
\mathrm{~N} \\
11 \\
\mathrm{~N} \\
\mathrm{~N}\end{array}$ & $\begin{array}{r}448 \\
2 \\
351 \\
7 \\
33 \\
55 \\
\end{array}$ & $\begin{array}{r}28 \\
- \\
5 \\
23 \\
- \\
-\end{array}$ & $\begin{array}{r}159 \\
- \\
114 \\
5 \\
16 \\
24 \\
\end{array}$ \\
\hline $\begin{array}{l}\text { Territories } \\
\text { American Samoa } \\
\text { C.N.M.I. } \\
\text { Guam } \\
\text { Puerto Rico } \\
\text { U.S. Virgin Islands }\end{array}$ & $\begin{array}{r}- \\
\overline{-} \\
489 \\
16\end{array}$ & $\begin{array}{l}- \\
\overline{-} \\
- \\
-\end{array}$ & $\begin{array}{l}\text { N } \\
- \\
- \\
-\end{array}$ & $\begin{array}{l}- \\
\overline{-} \\
-\end{array}$ & $\frac{N}{-}$ & $\begin{array}{l}- \\
\overline{69} \\
-\end{array}$ & $\begin{array}{l}\mathrm{N} \\
- \\
- \\
-\end{array}$ \\
\hline
\end{tabular}

N: Not Reportable U: Unavailable -: No reported cases C.N.M.I.: Commonwealth of the Northern Mariana Islands.

* No cases of anthrax; dengue hemorrhagic fever; eastern equine encephalitis, non-neuroinvasive; poliomyelitis, paralytic; poliovirus infection, nonparalytic; severe acute respiratory syndromeassociated coronavirus disease (SARS-CoV); smallpox; vancomycin-resistant Staphylococcus aureus (VRSA); western equine encephalitis virus disease, neuroinvasive and nonneuroinvasive; or yellow fever were reported in the United States during 2014.

† Totals reported to the Influenza Division, National Center for Immunization and Respiratory Diseases (NCIRD), as of June 30, 2015.

\$ Streptococcus pneumoniae, invasive disease. Since January 1, 2010, "Invasive pneumococcal disease (IPD)" has been nationally notifiable and separate notifications for "Drug resistant S. pneumoniae" and "IPD in children $<5$ years of age" have been discontinued. 
TABLE 2. (Continued) Reported cases of notifiable diseases, * by geographic division and area - United States, 2014

\begin{tabular}{|c|c|c|c|c|c|c|c|}
\hline \multirow[b]{2}{*}{ Area } & \multicolumn{3}{|c|}{ Lyme disease } & \multirow[b]{2}{*}{ Malaria } & \multicolumn{3}{|c|}{ Measles } \\
\hline & Total & Confirmed & Probable & & Total & Indigenous & Imported \\
\hline United States & 33,461 & 25,359 & 8,102 & 1,653 & 667 & 604 & 63 \\
\hline $\begin{array}{l}\text { New England } \\
\text { Connecticut } \\
\text { Maine } \\
\text { Massachusetts } \\
\text { New Hampshire } \\
\text { Rhode Island } \\
\text { Vermont }\end{array}$ & $\begin{array}{r}11,292 \\
2,360 \\
1,401 \\
5,304 \\
724 \\
904 \\
599\end{array}$ & $\begin{array}{r}8,168 \\
1,719 \\
1,169 \\
3,646 \\
622 \\
570 \\
442\end{array}$ & $\begin{array}{r}3,124 \\
641 \\
232 \\
1,658 \\
102 \\
334 \\
157\end{array}$ & $\begin{array}{r}120 \\
15 \\
7 \\
61 \\
11 \\
22 \\
4\end{array}$ & $\begin{array}{r}13 \\
5 \\
-8 \\
- \\
- \\
-\end{array}$ & $\begin{array}{l}6 \\
4 \\
-2 \\
- \\
- \\
-\end{array}$ & $\begin{array}{l}7 \\
1 \\
-6 \\
- \\
- \\
-\end{array}$ \\
\hline $\begin{array}{l}\text { Mid. Atlantic } \\
\text { New Jersey } \\
\text { New York (Upstate) } \\
\text { New York City } \\
\text { Pennsylvania }\end{array}$ & $\begin{array}{r}14,509 \\
3,286 \\
2,887 \\
849 \\
7,487\end{array}$ & $\begin{array}{r}11,912 \\
2,589 \\
2,285 \\
568 \\
6,470\end{array}$ & $\begin{array}{r}2,597 \\
697 \\
602 \\
281 \\
1,017\end{array}$ & $\begin{array}{r}427 \\
79 \\
59 \\
204 \\
85\end{array}$ & $\begin{array}{r}38 \\
3 \\
5 \\
27 \\
3\end{array}$ & $\begin{array}{r}30 \\
1 \\
2 \\
25 \\
2\end{array}$ & $\begin{array}{l}8 \\
2 \\
3 \\
2 \\
1\end{array}$ \\
\hline $\begin{array}{l}\text { E.N. Central } \\
\text { Illinois } \\
\text { Indiana } \\
\text { Michigan } \\
\text { Ohio } \\
\text { Wisconsin }\end{array}$ & $\begin{array}{r}1,950 \\
233 \\
110 \\
127 \\
119 \\
1,361\end{array}$ & $\begin{array}{r}1,511 \\
233 \\
100 \\
93 \\
94 \\
991\end{array}$ & $\begin{array}{r}439 \\
- \\
10 \\
34 \\
25 \\
370\end{array}$ & $\begin{array}{r}141 \\
55 \\
20 \\
17 \\
38 \\
11\end{array}$ & $\begin{array}{r}392 \\
2 \\
1 \\
5 \\
382 \\
2\end{array}$ & $\begin{array}{r}384 \\
1 \\
-3 \\
379 \\
1\end{array}$ & $\begin{array}{l}8 \\
1 \\
1 \\
2 \\
3 \\
1\end{array}$ \\
\hline $\begin{array}{l}\text { W.N. Central } \\
\text { lowa } \\
\text { Kansas } \\
\text { Minnesota } \\
\text { Missouri } \\
\text { Nebraska } \\
\text { North Dakota } \\
\text { South Dakota }\end{array}$ & $\begin{array}{r}1,663 \\
194 \\
20 \\
1,416 \\
10 \\
7 \\
14 \\
2\end{array}$ & $\begin{array}{r}1,035 \\
110 \\
12 \\
896 \\
7 \\
6 \\
2 \\
2\end{array}$ & $\begin{array}{r}628 \\
84 \\
8 \\
520 \\
3 \\
1 \\
12 \\
-\end{array}$ & $\begin{array}{r}115 \\
17 \\
9 \\
51 \\
15 \\
9 \\
9 \\
5\end{array}$ & $\begin{array}{r}52 \\
-14 \\
2 \\
27 \\
1 \\
-8\end{array}$ & $\begin{array}{r}48 \\
-13 \\
1 \\
25 \\
1 \\
-8 \\
8\end{array}$ & $\begin{array}{r}4 \\
- \\
1 \\
1 \\
2 \\
- \\
-\end{array}$ \\
\hline $\begin{array}{l}\text { S. Atlantic } \\
\text { Delaware } \\
\text { District of Columbia } \\
\text { Florida } \\
\text { Georgia } \\
\text { Maryland } \\
\text { North Carolina } \\
\text { South Carolina } \\
\text { Virginia } \\
\text { West Virginia }\end{array}$ & $\begin{array}{r}3,678 \\
417 \\
40 \\
155 \\
4 \\
1,373 \\
170 \\
37 \\
1,346 \\
136\end{array}$ & $\begin{array}{r}2,557 \\
341 \\
35 \\
85 \\
4 \\
957 \\
27 \\
20 \\
976 \\
112\end{array}$ & $\begin{array}{r}1,121 \\
76 \\
5 \\
70 \\
-116 \\
143 \\
17 \\
370 \\
24\end{array}$ & $\begin{array}{r}421 \\
2 \\
18 \\
52 \\
82 \\
146 \\
36 \\
6 \\
77 \\
2\end{array}$ & $\begin{array}{l}3 \\
- \\
- \\
- \\
- \\
\frac{1}{2} \\
-\end{array}$ & $\begin{array}{l}1 \\
- \\
= \\
= \\
= \\
= \\
-\end{array}$ & $\begin{array}{l}2 \\
- \\
= \\
- \\
- \\
\frac{1}{1} \\
-\end{array}$ \\
\hline $\begin{array}{l}\text { E.S. Central } \\
\text { Alabama } \\
\text { Kentucky } \\
\text { Mississippi } \\
\text { Tennessee }\end{array}$ & $\begin{array}{r}127 \\
64 \\
44 \\
2 \\
17\end{array}$ & $\begin{array}{r}48 \\
28 \\
11 \\
2 \\
7\end{array}$ & $\begin{array}{l}79 \\
36 \\
33 \\
10\end{array}$ & $\begin{array}{r}46 \\
14 \\
11 \\
1 \\
20\end{array}$ & $\begin{array}{r}5 \\
1 \\
- \\
- \\
4\end{array}$ & $\begin{array}{l}\frac{3}{-} \\
\frac{-}{3}\end{array}$ & $\begin{array}{r}2 \\
1 \\
- \\
-1\end{array}$ \\
\hline $\begin{array}{l}\text { W.S. Central } \\
\text { Arkansas } \\
\text { Louisiana } \\
\text { Oklahoma } \\
\text { Texas }\end{array}$ & $\frac{42}{\frac{2}{40}}$ & $\begin{array}{l}20 \\
\frac{-}{-} \\
\frac{20}{20}\end{array}$ & $\frac{22}{\frac{2}{20}}$ & $\begin{array}{r}143 \\
7 \\
20 \\
10 \\
106\end{array}$ & $\begin{array}{l}10 \\
\frac{-}{-} \\
\overline{10}\end{array}$ & $\begin{array}{l}\frac{7}{-} \\
\frac{-}{7}\end{array}$ & $\begin{array}{l}\frac{3}{-} \\
\frac{-}{3}\end{array}$ \\
\hline $\begin{array}{l}\text { Mountain } \\
\text { Arizona } \\
\text { Colorado } \\
\text { Idaho } \\
\text { Montana } \\
\text { Nevada } \\
\text { New Mexico } \\
\text { Utah } \\
\text { Wyoming }\end{array}$ & $\begin{array}{r}59 \\
21 \\
9 \\
7 \\
6 \\
\frac{13}{13} \\
3\end{array}$ & $\begin{array}{r}38 \\
14 \\
- \\
5 \\
4 \\
- \\
5 \\
2\end{array}$ & $\begin{array}{r}21 \\
7 \\
-1 \\
2 \\
2 \\
-8 \\
1\end{array}$ & $\begin{array}{r}79 \\
25 \\
30 \\
3 \\
2 \\
11 \\
3 \\
5 \\
-\end{array}$ & $\begin{array}{r}8 \\
3 \\
1 \\
- \\
- \\
1 \\
3 \\
-\end{array}$ & $\begin{array}{r}6 \\
3 \\
- \\
- \\
- \\
-1 \\
2 \\
-\end{array}$ & $\begin{array}{c}2 \\
- \\
-1 \\
- \\
- \\
-1 \\
-\end{array}$ \\
\hline $\begin{array}{l}\text { Pacific } \\
\text { Alaska } \\
\text { California } \\
\text { Hawaii } \\
\text { Oregon } \\
\text { Washington }\end{array}$ & $\begin{array}{r}141 \\
8 \\
73 \\
\mathrm{~N} \\
45 \\
15\end{array}$ & $\begin{array}{r}70 \\
5 \\
54 \\
N \\
3 \\
8\end{array}$ & $\begin{array}{r}71 \\
3 \\
19 \\
\mathrm{~N} \\
42 \\
7\end{array}$ & $\begin{array}{r}161 \\
4 \\
95 \\
4 \\
17 \\
41\end{array}$ & $\begin{array}{r}146 \\
92 \\
15 \\
6 \\
33\end{array}$ & $\begin{array}{r}119 \\
75 \\
10 \\
5 \\
29\end{array}$ & $\begin{array}{r}27 \\
17 \\
5 \\
1 \\
4\end{array}$ \\
\hline $\begin{array}{l}\text { Territories } \\
\text { American Samoa } \\
\text { C.N.M.I. } \\
\text { Guam } \\
\text { Puerto Rico } \\
\text { U.S. Virgin Islands }\end{array}$ & $\begin{array}{l}\mathrm{N} \\
- \\
\mathrm{N} \\
\mathrm{N}\end{array}$ & $\begin{array}{l}\mathrm{N} \\
\overline{-} \\
\mathrm{N} \\
\mathrm{N}\end{array}$ & $\begin{array}{l}\mathrm{N} \\
- \\
\mathrm{N} \\
\mathrm{N}\end{array}$ & $\begin{array}{l}- \\
\overline{-} \\
-\end{array}$ & $\begin{array}{l}- \\
- \\
2 \\
-\end{array}$ & $\begin{array}{l}- \\
\overline{2} \\
2 \\
-\end{array}$ & $\begin{array}{l}- \\
- \\
-\end{array}$ \\
\hline
\end{tabular}

N: Not Reportable U: Unavailable —: No reported cases C.N.M.I: Commonwealth of the Northern Mariana Islands.

* No cases of anthrax; dengue hemorrhagic fever; eastern equine encephalitis, non-neuroinvasive; poliomyelitis, paralytic; poliovirus infection, nonparalytic; severe acute respiratory syndromeassociated coronavirus disease (SARS-CoV); smallpox; vancomycin-resistant Staphylococcus aureus (VRSA); western equine encephalitis virus disease, neuroinvasive and nonneuroinvasive; or yellow fever were reported in the United States during 2014. 
TABLE 2. (Continued) Reported cases of notifiable diseases, ${ }^{*}$ by geographic division and area - United States, 2014

\begin{tabular}{|c|c|c|c|c|c|c|c|c|}
\hline \multirow[b]{2}{*}{ Area } & \multicolumn{5}{|c|}{ Meningococcal disease } & \multirow[b]{2}{*}{ Mumps } & \multirow[b]{2}{*}{$\begin{array}{l}\text { Novel influenza A } \\
\text { virus infections }{ }^{\dagger}\end{array}$} & \multirow[b]{2}{*}{ Pertussis } \\
\hline & $\begin{array}{c}\text { All } \\
\text { Serogroups } \\
\end{array}$ & $\begin{array}{c}\text { Serogroups } \\
\text { ACWY }\end{array}$ & Serogroup B & $\begin{array}{c}\text { Serogroup } \\
\text { Other }\end{array}$ & $\begin{array}{l}\text { Serogroup } \\
\text { Unknown }\end{array}$ & & & \\
\hline United States & 433 & 123 & 89 & 25 & 196 & 1,223 & 3 & 32,971 \\
\hline New England & 18 & 11 & 4 & 2 & 1 & 10 & - & 1,199 \\
\hline Connecticut & 3 & 3 & - & - & - & 3 & - & 100 \\
\hline Maine & 2 & 1 & - & 1 & - & - & - & 557 \\
\hline Massachusetts & 12 & 6 & 4 & 1 & 1 & 5 & - & 308 \\
\hline New Hampshire & - & - & - & - & - & 2 & - & 84 \\
\hline Rhode Island & 1 & 1 & - & - & - & - & - & 108 \\
\hline Vermont & - & - & - & - & - & - & - & 42 \\
\hline Mid. Atlantic & 51 & 7 & 11 & 3 & 30 & 193 & - & 2,223 \\
\hline New Jersey & 9 & - & - & - & 9 & 39 & - & 387 \\
\hline New York (Upstate) & 8 & 2 & 5 & 1 & - & 12 & - & 901 \\
\hline New York City & 18 & - & - & - & 18 & 123 & - & 122 \\
\hline Pennsylvania & 16 & 5 & 6 & 2 & 3 & 19 & - & 813 \\
\hline E.N. Central & 50 & 19 & 21 & 3 & 7 & 805 & 3 & 5,658 \\
\hline Illinois & 12 & 7 & 4 & 1 & - & 142 & - & 764 \\
\hline Indiana & 4 & - & 4 & - & - & 25 & - & 492 \\
\hline Michigan & 12 & 4 & 5 & - & 3 & 20 & - & 1,424 \\
\hline Ohio & 12 & 7 & 2 & - & 3 & 552 & 2 & 1,463 \\
\hline Wisconsin & 10 & 1 & 6 & 2 & 1 & 66 & 1 & 1,515 \\
\hline W.N.Central & 22 & 3 & 3 & - & 16 & 41 & - & 2,689 \\
\hline lowa & 2 & 1 & 1 & - & - & 10 & - & 222 \\
\hline Kansas & 1 & 1 & - & - & - & 2 & - & 431 \\
\hline Minnesota & 7 & - & - & - & 7 & 22 & - & 950 \\
\hline Missouri & 8 & - & - & - & 8 & 6 & - & 558 \\
\hline Nebraska & - & - & - & - & - & - & - & 366 \\
\hline North Dakota & 2 & 1 & 1 & - & - & 1 & - & 52 \\
\hline South Dakota & 2 & - & 1 & - & 1 & - & - & 110 \\
\hline S. Atlantic & 102 & 17 & 22 & 5 & 58 & 47 & - & 3,002 \\
\hline Delaware & 1 & - & 1 & - & - & - & - & 205 \\
\hline District of Columbia & 1 & - & 1 & - & - & 16 & - & 22 \\
\hline Florida & 50 & - & - & - & 50 & 1 & - & 719 \\
\hline Georgia & 14 & 7 & 2 & 1 & 4 & 2 & - & 408 \\
\hline Maryland & 7 & 2 & 4 & 1 & - & 3 & - & 203 \\
\hline North Carolina & 13 & 6 & 5 & - & 2 & 2 & - & 752 \\
\hline South Carolina & 5 & - & 3 & 1 & 1 & 2 & - & 170 \\
\hline Virginia & 10 & 2 & 6 & 1 & 1 & 20 & - & 505 \\
\hline West Virginia & 1 & - & - & 1 & - & 1 & - & 18 \\
\hline E.S. Central & 19 & 9 & 3 & - & 7 & 8 & - & 983 \\
\hline Alabama & 7 & 4 & 1 & - & 2 & 2 & - & 285 \\
\hline Kentucky & 3 & - & - & - & 3 & 2 & - & 300 \\
\hline Mississippi & 1 & - & - & - & 1 & - & - & 68 \\
\hline Tennessee & 8 & 5 & 2 & - & 1 & 4 & - & 330 \\
\hline W.S. Central & 40 & 15 & 8 & 6 & 11 & 21 & - & 3,094 \\
\hline Arkansas & 1 & 1 & - & - & - & 1 & - & 286 \\
\hline Louisiana & 7 & - & - & - & 7 & 1 & - & 90 \\
\hline Oklahoma & 10 & 3 & 4 & 3 & - & 4 & - & 142 \\
\hline Texas & 22 & 11 & 4 & 3 & 4 & 15 & - & 2,576 \\
\hline Mountain & 33 & 17 & 6 & 4 & 6 & 49 & - & 4,176 \\
\hline Arizona & 9 & 4 & 4 & 1 & - & 12 & - & 517 \\
\hline Colorado & 9 & 5 & 1 & 2 & 1 & 4 & - & 1,282 \\
\hline Idaho & 5 & 2 & 1 & 1 & 1 & 26 & - & 367 \\
\hline Montana & 4 & 4 & - & - & - & 1 & - & 494 \\
\hline Nevada & 3 & - & - & - & 3 & 2 & - & 144 \\
\hline New Mexico & 2 & 2 & - & - & - & 2 & - & 370 \\
\hline Utah & 1 & - & - & - & 1 & 2 & - & 940 \\
\hline Wyoming & - & - & - & - & - & - & - & 62 \\
\hline Pacific & 98 & 25 & 11 & 2 & 60 & 49 & - & 9,947 \\
\hline Alaska & 3 & 3 & - & - & - & 1 & - & 169 \\
\hline California & 57 & - & - & - & 57 & 37 & - & 8,723 \\
\hline Hawaii & 2 & 1 & - & 1 & - & 1 & - & 38 \\
\hline Oregon & 19 & 11 & 5 & - & 3 & 1 & - & 416 \\
\hline Washington & 17 & 10 & 6 & 1 & - & 9 & - & 601 \\
\hline \multicolumn{9}{|l|}{ Territories } \\
\hline American Samoa & - & - & - & - & - & - & - & - \\
\hline C.N.M.I. & - & - & - & - & - & - & - & - \\
\hline Guam & - & - & - & - & - & - & - & - \\
\hline Puerto Rico & - & - & - & - & - & - & - & 17 \\
\hline U.S. Virgin Islands & - & - & - & - & - & - & - & - \\
\hline
\end{tabular}

N: Not Reportable U: Unavailable _: No reported cases C.N.M.l.: Commonwealth of the Northern Mariana Islands.

* No cases of anthrax; dengue hemorrhagic fever; eastern equine encephalitis, non-neuroinvasive; poliomyelitis, paralytic; poliovirus infection, nonparalytic; severe acute respiratory syndromeassociated coronavirus disease (SARS-CoV); smallpox; vancomycin-resistant Staphylococcus aureus (VRSA); western equine encephalitis virus disease, neuroinvasive and nonneuroinvasive; or yellow fever were reported in the United States during 2014.

† Totals reported to the Influenza Division, National Center for Immunization and Respiratory Diseases (NCIRD), as of June 30, 2015. 
TABLE 2. (Continued) Reported cases of notifiable diseases, ${ }^{*}$ by geographic division and area - United States, 2014

\begin{tabular}{|c|c|c|c|c|c|c|c|c|}
\hline \multirow[b]{2}{*}{ Area } & \multirow[b]{2}{*}{ Plague } & \multirow[b]{2}{*}{ Psittacosis } & \multicolumn{3}{|c|}{ Q fever } & \multicolumn{2}{|c|}{ Rabies } & \multirow[b]{2}{*}{ Rubella } \\
\hline & & & Total & Acute & Chronic & Animal & Human & \\
\hline United States & 10 & 8 & 168 & 132 & 36 & 4,322 & 1 & 6 \\
\hline New England & - & - & 1 & - & 1 & 336 & - & - \\
\hline Connecticut & - & $\mathrm{N}$ & - & - & - & 188 & - & - \\
\hline Maine & - & - & - & - & - & 44 & - & - \\
\hline Massachusetts & - & - & 1 & - & 1 & - & - & - \\
\hline New Hampshire & - & - & $\mathrm{N}$ & $\mathrm{N}$ & $\mathrm{N}$ & 23 & - & - \\
\hline Rhode Island & - & - & - & - & - & 26 & - & - \\
\hline Vermont & - & - & $\mathrm{N}$ & - & - & 55 & - & - \\
\hline Mid. Atlantic & - & 1 & 18 & 13 & 5 & 776 & - & 1 \\
\hline New Jersey & - & 1 & 4 & 3 & 1 & - & - & - \\
\hline New York (Upstate) & - & - & 6 & 6 & - & 366 & - & - \\
\hline New York City & - & - & 2 & - & 2 & 12 & - & - \\
\hline Pennsylvania & - & - & 6 & 4 & 2 & 398 & - & 1 \\
\hline E.N. Central & - & - & 18 & 8 & 10 & 108 & - & 1 \\
\hline Illinois & - & - & 4 & 2 & 2 & 40 & - & 1 \\
\hline Indiana & - & - & 2 & 2 & - & 4 & - & - \\
\hline Michigan & - & - & 2 & 1 & 1 & 41 & - & - \\
\hline Ohio & - & - & 4 & - & 4 & 23 & - & - \\
\hline Wisconsin & - & - & 6 & 3 & 3 & $\mathrm{~N}$ & - & - \\
\hline W.N.Central & - & 5 & 15 & 14 & 1 & 138 & 1 & 1 \\
\hline lowa & - & - & $\mathrm{N}$ & $\mathrm{N}$ & $\mathrm{N}$ & - & - & - \\
\hline Kansas & - & - & 2 & 2 & - & 69 & - & - \\
\hline Minnesota & - & - & 3 & 3 & - & - & - & - \\
\hline Missouri & - & - & 1 & 1 & - & 27 & 1 & - \\
\hline Nebraska & - & 5 & 2 & 2 & - & 21 & - & 1 \\
\hline North Dakota & - & - & 2 & 2 & - & - & - & - \\
\hline South Dakota & - & - & 5 & 4 & 1 & 21 & - & - \\
\hline S. Atlantic & - & 1 & 11 & 10 & 1 & 1,105 & - & - \\
\hline Delaware & - & - & - & - & - & - & - & - \\
\hline District of Columbia & - & - & $\mathrm{N}$ & - & - & - & - & - \\
\hline Florida & - & 1 & 1 & 1 & - & 94 & - & - \\
\hline Georgia & - & - & - & - & - & 270 & - & - \\
\hline Maryland & - & - & - & - & - & 344 & - & - \\
\hline North Carolina & - & - & 3 & 3 & - & 355 & - & - \\
\hline South Carolina & - & - & - & - & - & $\mathrm{N}$ & - & - \\
\hline Virginia & - & - & 4 & 3 & 1 & - & - & - \\
\hline West Virginia & - & - & 3 & 3 & - & 42 & - & - \\
\hline E.S. Central & - & - & 4 & 4 & - & 88 & - & - \\
\hline Alabama & - & - & 2 & 2 & - & 78 & - & - \\
\hline Kentucky & - & - & - & - & - & 9 & - & - \\
\hline Mississippi & - & - & - & - & - & 1 & - & - \\
\hline Tennessee & - & - & 2 & 2 & - & - & - & - \\
\hline W.S.Central & - & - & 22 & 14 & 8 & 1,395 & - & - \\
\hline Arkansas & - & - & 5 & 5 & $\mathrm{~N}$ & 151 & - & - \\
\hline Louisiana & - & - & 1 & 1 & - & 5 & - & - \\
\hline Oklahoma & - & - & 4 & 2 & 2 & 107 & - & - \\
\hline Texas & - & $\mathrm{N}$ & 12 & 6 & 6 & 1,132 & - & - \\
\hline Mountain & 10 & - & 34 & 24 & 10 & 133 & - & 1 \\
\hline Arizona & - & - & 9 & 6 & 3 & $\mathrm{~N}$ & - & - \\
\hline Colorado & 8 & - & 6 & 4 & 2 & - & - & - \\
\hline Idaho & - & - & 4 & 4 & - & 12 & - & - \\
\hline Montana & - & - & 4 & 2 & 2 & 16 & - & - \\
\hline Nevada & - & - & - & - & - & 12 & - & - \\
\hline New Mexico & 2 & - & 2 & 2 & - & 12 & - & - \\
\hline Utah & - & - & 9 & 6 & 3 & 22 & - & 1 \\
\hline Wyoming & - & - & - & - & - & 59 & - & - \\
\hline Pacific & - & 1 & 45 & 45 & - & 243 & - & 2 \\
\hline Alaska & - & - & - & - & - & 3 & - & - \\
\hline California & - & - & 35 & 35 & - & 212 & - & 2 \\
\hline Hawaii & - & - & - & - & - & - & - & - \\
\hline Oregon & - & - & 9 & 9 & - & 13 & - & - \\
\hline Washington & - & 1 & 1 & 1 & - & 15 & - & - \\
\hline \multicolumn{9}{|l|}{ Territories } \\
\hline American Samoa & - & $\mathrm{N}$ & $\mathrm{N}$ & $\mathrm{N}$ & $\mathrm{N}$ & u & U & - \\
\hline C.N.M.I. & - & - & - & - & - & - & - & - \\
\hline Guam & - & - & $\mathrm{N}$ & $\mathrm{N}$ & $\mathrm{N}$ & - & - & - \\
\hline Puerto Rico & - & $\mathrm{N}$ & - & - & - & 39 & - & - \\
\hline U.S. Virgin Islands & - & - & - & - & - & - & - & - \\
\hline
\end{tabular}

N: Not Reportable U: Unavailable -: No reported cases C.N.M.I.: Commonwealth of the Northern Mariana Islands.

* No cases of anthrax; dengue hemorrhagic fever; eastern equine encephalitis, non-neuroinvasive; poliomyelitis, paralytic; poliovirus infection, nonparalytic; severe acute respiratory syndromeassociated coronavirus disease (SARS-CoV); smallpox; vancomycin-resistant Staphylococcus aureus (VRSA); western equine encephalitis virus disease, neuroinvasive and nonneuroinvasive; or yellow fever were reported in the United States during 2014. 
TABLE 2. (Continued) Reported cases of notifiable diseases, * by geographic division and area - United States, 2014

\begin{tabular}{|c|c|c|c|c|c|c|c|c|}
\hline \multirow[b]{2}{*}{ Area } & \multirow{2}{*}{$\begin{array}{c}\text { Rubella, } \\
\text { Congenital } \\
\text { syndrome }\end{array}$} & \multirow[b]{2}{*}{ Salmonellosis } & \multirow{2}{*}{$\begin{array}{c}\text { Shiga } \\
\text { toxin-producing } \\
\text { Escherichia Coli } \\
\text { (STEC) }{ }^{\dagger}\end{array}$} & \multirow[b]{2}{*}{ Shigellosis } & \multicolumn{3}{|c|}{ Spotted Fever Rickettsiosis ${ }^{\S}$} & \multirow{2}{*}{$\begin{array}{l}\text { Streptococcal } \\
\text { toxic-shock } \\
\text { syndrome }\end{array}$} \\
\hline & & & & & Total & Confirmed & Probable & \\
\hline United States & 1 & 51,455 & 6,179 & 20,745 & 3,647 & 115 & 3,524 & 259 \\
\hline New England & - & 2,231 & 223 & 335 & 19 & 1 & 18 & 46 \\
\hline Connecticut & - & 457 & 60 & 67 & 6 & - & 6 & 19 \\
\hline Maine & - & 127 & 33 & 29 & 3 & - & 3 & 18 \\
\hline Massachusetts & - & 1,223 & 95 & 187 & 8 & - & 8 & 6 \\
\hline New Hampshire & - & 191 & 16 & 14 & 2 & 1 & 1 & - \\
\hline Rhode Island & - & 140 & 4 & 34 & - & - & - & 1 \\
\hline Vermont & - & 93 & 15 & 4 & - & - & - & 2 \\
\hline Mid. Atlantic & - & 4,968 & 577 & 1,224 & 86 & 2 & 84 & 50 \\
\hline New Jersey & - & 1,170 & 124 & 297 & 58 & - & 58 & 37 \\
\hline New York (Upstate) & - & 1,320 & 200 & 281 & 20 & 1 & 19 & 13 \\
\hline New York City & - & 1,008 & 70 & 443 & 1 & - & 1 & - \\
\hline Pennsylvania & - & 1,470 & 183 & 203 & 7 & 1 & 6 & - \\
\hline E.N. Central & 1 & 5,672 & 871 & 3,475 & 148 & 2 & 146 & 78 \\
\hline Illinois & 1 & 1,778 & 195 & 840 & 89 & 1 & 88 & 52 \\
\hline Indiana & - & 725 & 117 & 1,362 & 36 & - & 36 & 12 \\
\hline Michigan & - & 1,053 & 133 & 310 & - & - & - & 4 \\
\hline Ohio & - & 1,199 & 204 & 606 & 12 & - & 12 & 9 \\
\hline Wisconsin & - & 917 & 222 & 357 & 11 & 1 & 10 & 1 \\
\hline W.N.Central & - & 3,038 & 1,013 & 2,615 & 301 & 8 & 293 & 11 \\
\hline lowa & - & 527 & 224 & 208 & 10 & - & 10 & - \\
\hline Kansas & - & 428 & 90 & 55 & - & - & - & 2 \\
\hline Minnesota & - & 727 & 332 & 95 & 7 & - & 7 & 8 \\
\hline Missouri & - & 839 & 180 & 1,395 & 265 & 2 & 263 & 1 \\
\hline Nebraska & - & 259 & 107 & 220 & 13 & 3 & 10 & - \\
\hline North Dakota & - & 88 & 39 & 21 & 3 & 2 & 1 & - \\
\hline South Dakota & - & 170 & 41 & 621 & 3 & 1 & 2 & - \\
\hline S. Atlantic & - & 14,163 & 514 & 4,768 & 1,002 & 56 & 946 & 35 \\
\hline Delaware & - & 157 & 14 & 74 & 24 & - & 24 & - \\
\hline District of Columbia & - & 64 & 5 & 118 & - & - & - & - \\
\hline Florida & - & 6,019 & 117 & 2,396 & 29 & 2 & 27 & $\mathrm{~N}$ \\
\hline Georgia & - & 2,242 & 97 & 1,021 & 37 & 37 & - & - \\
\hline Maryland & - & 894 & 74 & 260 & 6 & 2 & 4 & 4 \\
\hline North Carolina & - & 2,057 & 51 & 510 & 496 & 10 & 486 & 20 \\
\hline South Carolina & - & 1,399 & 15 & 162 & 32 & 1 & 31 & 1 \\
\hline Virginia & - & 1,151 & 121 & 214 & 373 & 4 & 369 & 10 \\
\hline West Virginia & - & 180 & 20 & 13 & 5 & - & 5 & - \\
\hline E.S. Central & - & 3,738 & 323 & 1,893 & 881 & 25 & 850 & 4 \\
\hline Alabama & - & 1,165 & 41 & 516 & 220 & 8 & 206 & - \\
\hline Kentucky & - & 585 & 97 & 344 & 53 & - & 53 & 4 \\
\hline Mississippi & - & 990 & 31 & 199 & 50 & 4 & 46 & $\mathrm{~N}$ \\
\hline Tennessee & - & 998 & 154 & 834 & 558 & 13 & 545 & - \\
\hline W.S. Central & - & 7,821 & 843 & 3,791 & 1,155 & 3 & 1,152 & 2 \\
\hline Arkansas & - & 668 & 89 & 770 & 824 & - & 824 & - \\
\hline Louisiana & - & 1,210 & 18 & 139 & 18 & - & 18 & 2 \\
\hline Oklahoma & - & 798 & 124 & 139 & 219 & 3 & 216 & $\mathrm{~N}$ \\
\hline Texas & - & 5,145 & 612 & 2,743 & 94 & - & 94 & $\mathrm{~N}$ \\
\hline Mountain & - & 2,933 & 627 & 749 & 37 & 10 & 25 & 33 \\
\hline Arizona & - & 1,046 & 98 & 376 & 16 & 6 & 10 & 4 \\
\hline Colorado & - & 616 & 168 & 80 & 5 & 1 & 4 & 2 \\
\hline Idaho & - & 174 & 116 & 12 & 1 & - & 1 & 1 \\
\hline Montana & - & 146 & 39 & 44 & 4 & 1 & 3 & - \\
\hline Nevada & - & 173 & 36 & 36 & 1 & - & 1 & 12 \\
\hline New Mexico & - & 333 & 47 & 64 & 2 & 1 & 1 & - \\
\hline Utah & - & 370 & 91 & 41 & 8 & 1 & 5 & 13 \\
\hline Wyoming & - & 75 & 32 & 96 & - & - & - & 1 \\
\hline Pacific & - & 6,891 & 1,188 & 1,895 & 18 & 8 & 10 & - \\
\hline Alaska & - & 68 & - & 4 & $\mathrm{~N}$ & $\mathrm{~N}$ & $\mathrm{~N}$ & $\mathrm{~N}$ \\
\hline California & - & 5,358 & 691 & 1,655 & 11 & 5 & 6 & $\mathrm{~N}$ \\
\hline Hawaii & - & 323 & 25 & 29 & $\mathrm{~N}$ & $\mathrm{~N}$ & $\mathrm{~N}$ & - \\
\hline Oregon & - & 401 & 185 & 50 & 5 & 2 & 3 & $\mathrm{~N}$ \\
\hline Washington & - & 741 & 287 & 157 & 2 & 1 & 1 & $\mathrm{~N}$ \\
\hline \multicolumn{9}{|l|}{ Territories } \\
\hline American Samoa & - & - & - & - & N & N & $\mathrm{N}$ & $\mathrm{N}$ \\
\hline C.N.M.I. & - & - & - & - & - & - & - & - \\
\hline Guam & - & 13 & - & 4 & $\mathrm{~N}$ & $\mathrm{~N}$ & $\mathrm{~N}$ & - \\
\hline Puerto Rico & $\mathrm{N}$ & 832 & 5 & 26 & $\mathrm{~N}$ & $\mathrm{~N}$ & $\mathrm{~N}$ & $\mathrm{~N}$ \\
\hline U.S. Virgin Islands & - & - & - & - & $\mathrm{N}$ & $\mathrm{N}$ & $\mathrm{N}$ & - \\
\hline
\end{tabular}

N: Not Reportable U: Unavailable _: No reported cases C.N.M.I: Commonwealth of the Northern Mariana Islands.

* No cases of anthrax; dengue hemorrhagic fever; eastern equine encephalitis, non-neuroinvasive; poliomyelitis, paralytic; poliovirus infection, nonparalytic; severe acute respiratory syndromeassociated coronavirus disease (SARS-CoV); smallpox; vancomycin-resistant Staphylococcus aureus (VRSA); western equine encephalitis virus disease, neuroinvasive and nonneuroinvasive; or yellow fever were reported in the United States during 2014.

† Includes E. coli O157:H7; Shiga toxin-positive, serogroup non-0157; and Shiga toxin positive, not serogrouped.

$\S$ Total case count includes eight unknown case status reports. 
TABLE 2. (Continued) Reported cases of notifiable diseases, * by geographic division and area - United States, 2014

\begin{tabular}{|c|c|c|c|c|c|c|}
\hline \multirow[b]{2}{*}{ Area } & \multicolumn{3}{|c|}{ Syphilis ${ }^{t, \S}$} & \multirow[b]{2}{*}{ Tetanus } & \multirow[b]{2}{*}{ Toxic-shock syndrome } & \multirow[b]{2}{*}{ Trichinellosis } \\
\hline & All Stages & Primary \& Secondary & Congenital & & & \\
\hline United States & 63,450 & 19,999 & 458 & 25 & 59 & 14 \\
\hline New England & 1,256 & 515 & 3 & - & 2 & - \\
\hline Connecticut & 169 & 86 & - & - & $\mathrm{N}$ & - \\
\hline Maine & 23 & 16 & - & - & - & - \\
\hline Massachusetts & 813 & 301 & 3 & - & - & - \\
\hline New Hampshire & 79 & 36 & - & - & - & - \\
\hline Rhode Island & 160 & 71 & - & - & 1 & - \\
\hline Vermont & 12 & 5 & - & - & 1 & - \\
\hline Mid. Atlantic & 9,825 & 2,556 & 27 & 2 & 7 & - \\
\hline New Jersey & 1,172 & 297 & - & - & 2 & - \\
\hline New York (Upstate) & 1,341 & 401 & 3 & - & 4 & - \\
\hline New York City & 5,788 & 1,326 & 19 & - & - & - \\
\hline Pennsylvania & 1,524 & 532 & 5 & 2 & 1 & - \\
\hline E.N.Central & 5,880 & 2,106 & 65 & 3 & 17 & 3 \\
\hline Illinois & 2,796 & 863 & 27 & - & 2 & - \\
\hline Indiana & 475 & 168 & 8 & 1 & - & 1 \\
\hline Michigan & 1,095 & 421 & 15 & - & 4 & 1 \\
\hline Ohio & 1,229 & 568 & 15 & 1 & 9 & 1 \\
\hline Wisconsin & 285 & 86 & - & 1 & 2 & - \\
\hline W.N.Central & 2,083 & 857 & 6 & 2 & 6 & - \\
\hline lowa & 239 & 72 & 1 & - & 1 & - \\
\hline Kansas & 200 & 60 & - & - & - & - \\
\hline Minnesota & 631 & 257 & - & 2 & 5 & - \\
\hline Missouri & 771 & 352 & 1 & - & - & - \\
\hline Nebraska & 96 & 50 & 1 & - & - & - \\
\hline North Dakota & 51 & 13 & - & - & - & - \\
\hline South Dakota & 95 & 53 & 3 & - & - & - \\
\hline S. Atlantic & 14,857 & 4,886 & 93 & 3 & 9 & 1 \\
\hline Delaware & 110 & 47 & - & - & 1 & - \\
\hline District of Columbia & 281 & 116 & - & - & - & - \\
\hline $\begin{array}{l}\text { Florida } \\
\text { latal }\end{array}$ & 6,102 & 1,740 & 47 & 2 & $\mathrm{~N}$ & - \\
\hline Georgia & 3,384 & 1,234 & 17 & - & 4 & $\mathrm{~N}$ \\
\hline Maryland & 1,475 & 449 & 16 & 1 & $\mathrm{~N}$ & - \\
\hline North Carolina & 1,998 & 733 & 6 & - & 2 & - \\
\hline South Carolina & 750 & 250 & 5 & - & 1 & - \\
\hline Virginia & 702 & 289 & 2 & - & $\mathrm{N}$ & 1 \\
\hline West Virginia & 55 & 28 & - & - & 1 & - \\
\hline E.S. Central & 2,541 & 745 & 9 & 1 & 6 & - \\
\hline Alabama & 475 & 161 & 3 & - & - & - \\
\hline Kentucky & 447 & 158 & 3 & - & 1 & - \\
\hline Mississippi & 642 & 189 & 1 & 1 & $\mathrm{~N}$ & - \\
\hline Tennessee & 977 & 237 & 2 & - & 5 & - \\
\hline W.S. Central & 10,780 & 2,483 & 132 & 6 & 2 & 2 \\
\hline Arkansas & 389 & 121 & 6 & - & 2 & $\mathrm{~N}$ \\
\hline Louisiana & 2,173 & 575 & 46 & 1 & - & - \\
\hline Oklahoma & 414 & 151 & 6 & 1 & $\mathrm{~N}$ & - \\
\hline Texas & 7,804 & 1,636 & 74 & 4 & $\mathrm{~N}$ & 2 \\
\hline Mountain & 3,201 & 1,317 & 20 & - & 7 & 2 \\
\hline Arizona & 1,459 & 577 & 13 & - & 2 & - \\
\hline Colorado & 355 & 186 & - & - & 4 & 1 \\
\hline Idaho & 46 & 12 & - & - & - & - \\
\hline Montana & 9 & 8 & - & - & - & - \\
\hline Nevada & 894 & 357 & 6 & - & - & - \\
\hline New Mexico & 283 & 126 & 1 & - & - & - \\
\hline Utah & 149 & 47 & - & - & 1 & 1 \\
\hline Wyoming & 6 & 4 & - & - & - & - \\
\hline Pacific & 13,027 & 4,534 & 103 & 8 & 3 & 6 \\
\hline Alaska & 45 & 15 & - & 1 & $\mathrm{~N}$ & 2 \\
\hline California & 11,440 & 3,835 & 99 & 4 & 3 & 2 \\
\hline Hawaii & 106 & 68 & - & - & $\mathrm{N}$ & - \\
\hline Oregon & 582 & 272 & 2 & - & $\mathrm{N}$ & - \\
\hline Washington & 854 & 344 & 2 & 3 & $\mathrm{~N}$ & 2 \\
\hline \multicolumn{7}{|l|}{ Territories } \\
\hline American Samoa & - & - & - & - & $\mathrm{N}$ & $\mathrm{N}$ \\
\hline C.N.M.I. & - & - & - & - & - & - \\
\hline Guam & 13 & 7 & - & - & - & - \\
\hline Puerto Rico & 960 & 484 & - & - & $\mathrm{N}$ & $\mathrm{N}$ \\
\hline U.S. Virgin Islands & 6 & 2 & - & - & - & - \\
\hline
\end{tabular}

N: Not Reportable U: Unavailable _: No reported cases C.N.M.I.: Commonwealth of the Northern Mariana Islands.

* No cases of anthrax; dengue hemorrhagic fever; eastern equine encephalitis, non-neuroinvasive; poliomyelitis, paralytic; poliovirus infection, nonparalytic; severe acute respiratory syndromeassociated coronavirus disease (SARS-CoV); smallpox; vancomycin-resistant Staphylococcus aureus (VRSA); western equine encephalitis virus disease, neuroinvasive and nonneuroinvasive; or yellow fever were reported in the United States during 2014.

+ Includes the following categories: primary, secondary, latent (including early latent, late latent, and latent syphilis of unknown duration), neurosyphilis, late (including late syphilis with clinical manifestations other than neurosyphilis), and congenital syphilis.

$\S$ Totals reported to the Division of STD Prevention, NCHHSTP, as of June 10, 2015. 
TABLE 2. (Continued) Reported cases of notifiable diseases, ${ }^{*}$ by geographic division and area - United States, 2014

\begin{tabular}{|c|c|c|c|c|}
\hline Area & Tuberculosis $^{\dagger}$ & Tularemia & Typhoid fever & $\begin{array}{c}\text { Vancomycin-intermediate } \\
\text { Staphylococcus aureus (VISA) }\end{array}$ \\
\hline United States & 9,421 & 180 & 349 & 212 \\
\hline $\begin{array}{r}\text { New England } \\
\text { Connecticut }\end{array}$ & $\begin{array}{r}307 \\
60\end{array}$ & 4 & $\begin{array}{r}19 \\
1\end{array}$ & 2 \\
\hline Maine & 14 & - & - & 1 \\
\hline Massachusetts & 199 & 3 & 15 & - \\
\hline New Hampshire & 11 & - & 1 & $\mathrm{~N}$ \\
\hline Rhode Island & 21 & - & 2 & 1 \\
\hline Vermont & 2 & 1 & - & - \\
\hline Mid. Atlantic & 1,304 & 4 & 85 & 62 \\
\hline New Jersey & 308 & 1 & 21 & 7 \\
\hline New York (Upstate) & 202 & 3 & 10 & 31 \\
\hline New York City & 585 & - & 39 & 20 \\
\hline Pennsylvania & 209 & - & 15 & 4 \\
\hline E.N. Central & 736 & 12 & 38 & 17 \\
\hline Illinois & 320 & 7 & 15 & 3 \\
\hline Indiana & 108 & 2 & 5 & - \\
\hline Michigan & 105 & 2 & 9 & 3 \\
\hline Ohio & 156 & 1 & 7 & 9 \\
\hline Wisconsin & 47 & - & 2 & 2 \\
\hline W.N.Central & 381 & 63 & 15 & 106 \\
\hline lowa & 54 & 1 & 1 & $\mathrm{~N}$ \\
\hline Kansas & 40 & 27 & 1 & - \\
\hline Minnesota & 147 & - & 6 & - \\
\hline Missouri & 79 & 20 & 5 & 104 \\
\hline Nebraska & 38 & 6 & - & - \\
\hline North Dakota & 15 & 4 & 2 & - \\
\hline South Dakota & 8 & 5 & - & 2 \\
\hline S. Atlantic & 1,667 & 2 & 56 & 16 \\
\hline Delaware & 22 & - & 4 & - \\
\hline District of Columbia & 32 & - & - & - \\
\hline Florida & 595 & 1 & 13 & 4 \\
\hline Georgia & 335 & - & 10 & 3 \\
\hline Maryland & 198 & - & 16 & 1 \\
\hline North Carolina & 195 & - & 4 & 4 \\
\hline South Carolina & 79 & - & - & 1 \\
\hline Virginia & 198 & - & 9 & 3 \\
\hline West Virginia & 13 & 1 & - & - \\
\hline E.S. Central & 438 & 3 & 4 & 3 \\
\hline Alabama & 133 & - & 2 & 2 \\
\hline Kentucky & 80 & 1 & - & - \\
\hline Mississippi & 74 & - & - & - \\
\hline Tennessee & 151 & 2 & 2 & 1 \\
\hline W.S. Central & 1,542 & 60 & 23 & 5 \\
\hline Arkansas & 93 & 42 & 1 & - \\
\hline Louisiana & 121 & 1 & - & - \\
\hline Oklahoma & 59 & 17 & 2 & - \\
\hline Texas & 1,269 & - & 20 & 5 \\
\hline Mountain & 431 & 24 & 21 & 1 \\
\hline Arizona & 193 & - & 4 & - \\
\hline Colorado & 64 & 16 & 6 & $\mathrm{~N}$ \\
\hline Idaho & 11 & - & - & $\mathrm{N}$ \\
\hline Montana & 6 & 1 & 3 & - \\
\hline Nevada & 74 & - & 3 & - \\
\hline New Mexico & 50 & 5 & 1 & $\mathrm{~N}$ \\
\hline Utah & 31 & 1 & 4 & 1 \\
\hline Wyoming & 2 & 1 & - & - \\
\hline $\begin{array}{l}\text { Pacific } \\
\text { Pal }\end{array}$ & 2,615 & 8 & 88 & - \\
\hline Alaska & 62 & - & - & $\mathrm{N}$ \\
\hline California & 2,145 & - & 66 & $\mathrm{~N}$ \\
\hline Hawaii & 136 & - & 4 & - \\
\hline Oregon & 77 & 4 & 3 & $\mathrm{~N}$ \\
\hline Washington & 195 & 4 & 15 & $\mathrm{~N}$ \\
\hline \multicolumn{5}{|l|}{ Territories } \\
\hline American Samoa & 1 & - & - & $\mathrm{N}$ \\
\hline C.N.M.I. & 23 & - & - & - \\
\hline Guam & 56 & - & - & - \\
\hline Puerto Rico & 44 & - & 1 & - \\
\hline U.S. Virgin Islands & - & - & - & - \\
\hline
\end{tabular}


Morbidity and Mortality Weekly Report

TABLE 2. (Continued) Reported cases of notifiable diseases, ${ }^{*}$ by geographic division and area - United States, 2014

\begin{tabular}{|c|c|c|c|c|}
\hline \multirow[b]{2}{*}{ Area } & \multicolumn{2}{|c|}{ Varicella } & \multirow[b]{2}{*}{ Vibriosis } & \multirow[b]{2}{*}{ Viral hemorrhagic fever ${ }^{\S}$} \\
\hline & Morbidity & Mortality $^{\dagger}$ & & \\
\hline United States & 10,172 & 3 & 1,261 & 5 \\
\hline New England & 1,147 & - & 86 & - \\
\hline Connecticut & 186 & - & 15 & - \\
\hline Maine & 207 & - & 9 & - \\
\hline Massachusetts & 470 & $\mathrm{~N}$ & 51 & - \\
\hline New Hampshire & 112 & - & 5 & - \\
\hline Rhode Island & 54 & - & 6 & - \\
\hline Vermont & 118 & - & - & - \\
\hline Mid. Atlantic & 1,151 & - & 70 & 1 \\
\hline New Jersey & 317 & - & 34 & - \\
\hline New York (Upstate) & $\mathrm{N}$ & $\mathrm{N}$ & $\mathrm{N}$ & - \\
\hline New York City & - & - & 17 & 1 \\
\hline Pennsylvaniá & 834 & - & 19 & - \\
\hline E.N.Central & 2,498 & - & 63 & - \\
\hline Illinois & 596 & - & 24 & - \\
\hline Indiana & 220 & - & 6 & - \\
\hline Michigan & 728 & - & 7 & - \\
\hline $\begin{array}{l}\text { Ohio } \\
\text { On }\end{array}$ & 535 & $\mathrm{~N}$ & 12 & - \\
\hline Wisconsin & 419 & - & 14 & - \\
\hline W.N.Central & 855 & - & 38 & 1 \\
\hline lowa & $\mathrm{N}$ & $\mathrm{N}$ & $\mathrm{N}$ & - \\
\hline Kansas & 294 & - & 2 & - \\
\hline Minnesota & 297 & - & 25 & 1 \\
\hline Missouri & 201 & - & 8 & - \\
\hline Nebraska & 19 & - & 2 & - \\
\hline North Dakota & 21 & - & 1 & - \\
\hline South Dakota & 23 & - & $\mathrm{N}$ & - \\
\hline S. Atlantic & 1,282 & 2 & 326 & - \\
\hline Delaware & 15 & - & 5 & - \\
\hline District of Columbia & - & - & 1 & - \\
\hline Florida & 570 & 1 & 166 & - \\
\hline Georgia & 64 & 1 & 18 & - \\
\hline Maryland & $\mathrm{N}$ & - & 42 & - \\
\hline North Carolina & $\mathrm{N}$ & $\mathrm{N}$ & 14 & - \\
\hline South Carolina & 151 & - & 18 & - \\
\hline Virginia & 324 & $\mathrm{~N}$ & 59 & - \\
\hline West Virginia & 158 & $\mathrm{~N}$ & 3 & - \\
\hline E.S. Central & 111 & - & 55 & - \\
\hline Alabama & 107 & - & 20 & - \\
\hline Kentucky & $\mathrm{N}$ & $\mathrm{N}$ & 9 & - \\
\hline Mississippi & 4 & $\mathrm{~N}$ & 11 & - \\
\hline Tennessee & $\mathrm{N}$ & - & 15 & - \\
\hline W.S. Central & 1,943 & 1 & 130 & 3 \\
\hline Arkansas & 254 & $\mathrm{~N}$ & $\mathrm{~N}$ & - \\
\hline Louisiana & 42 & - & 50 & - \\
\hline Oklahoma & $\mathrm{N}$ & $\mathrm{N}$ & 2 & - \\
\hline Texas & 1,647 & 1 & 78 & 3 \\
\hline Mountain & 1,059 & - & 57 & - \\
\hline Arizona & 300 & - & 36 & - \\
\hline Colorado & 386 & $\mathrm{~N}$ & 13 & - \\
\hline Idaho & $\mathrm{N}$ & $\mathrm{N}$ & $\mathrm{N}$ & - \\
\hline Montana & 72 & - & 2 & - \\
\hline Nevada & $\mathrm{N}$ & $\mathrm{N}$ & 2 & - \\
\hline New Mexico & 75 & $\mathrm{~N}$ & 1 & - \\
\hline Utah & 215 & - & 2 & - \\
\hline Wyoming & 11 & $\mathrm{~N}$ & 1 & - \\
\hline Pacific & 126 & - & 436 & - \\
\hline Alaska & 31 & - & 5 & - \\
\hline California & 43 & - & 272 & - \\
\hline Hawaii & 52 & - & 38 & - \\
\hline Oregon & $\mathrm{N}$ & $\mathrm{N}$ & 29 & - \\
\hline Washington & $\mathrm{N}$ & - & 92 & - \\
\hline Territories & & & & \\
\hline American Samoa & $\mathrm{N}$ & $\mathrm{N}$ & $\mathrm{N}$ & - \\
\hline C.N.M.I. & - & - & - & - \\
\hline Guam & 33 & $\mathrm{~N}$ & - & - \\
\hline Puerto Rico & 231 & - & - & - \\
\hline U.S. Virgin Islands & - & - & - & - \\
\hline
\end{tabular}

N: Not Reportable U: Unavailable -: No reported cases C.N.M.I.: Commonwealth of the Northern Mariana Islands.

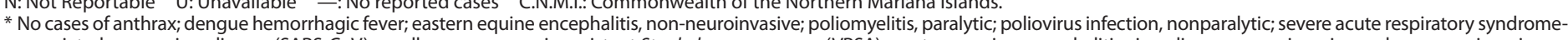

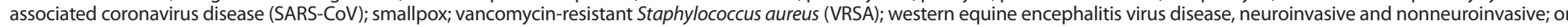
yellow fever were reported in the United States during 2014.

† Totals reported to the Division of Viral Diseases, National Center for Immunization and Respiratory Diseases (NCIRD), as of June $30,2015$.

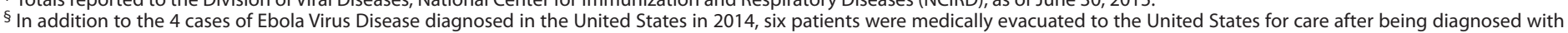
Ebola Virus Disease in West Africa. In total, 11 VHF cases were reported for 2014, 10 confirmed infections with Ebola virus and one confirmed infection with Lassa virus. 


\section{Age-Adjusted Death Rates* for Parkinson Disease ${ }^{\dagger}$ - United States, 2000-2013}

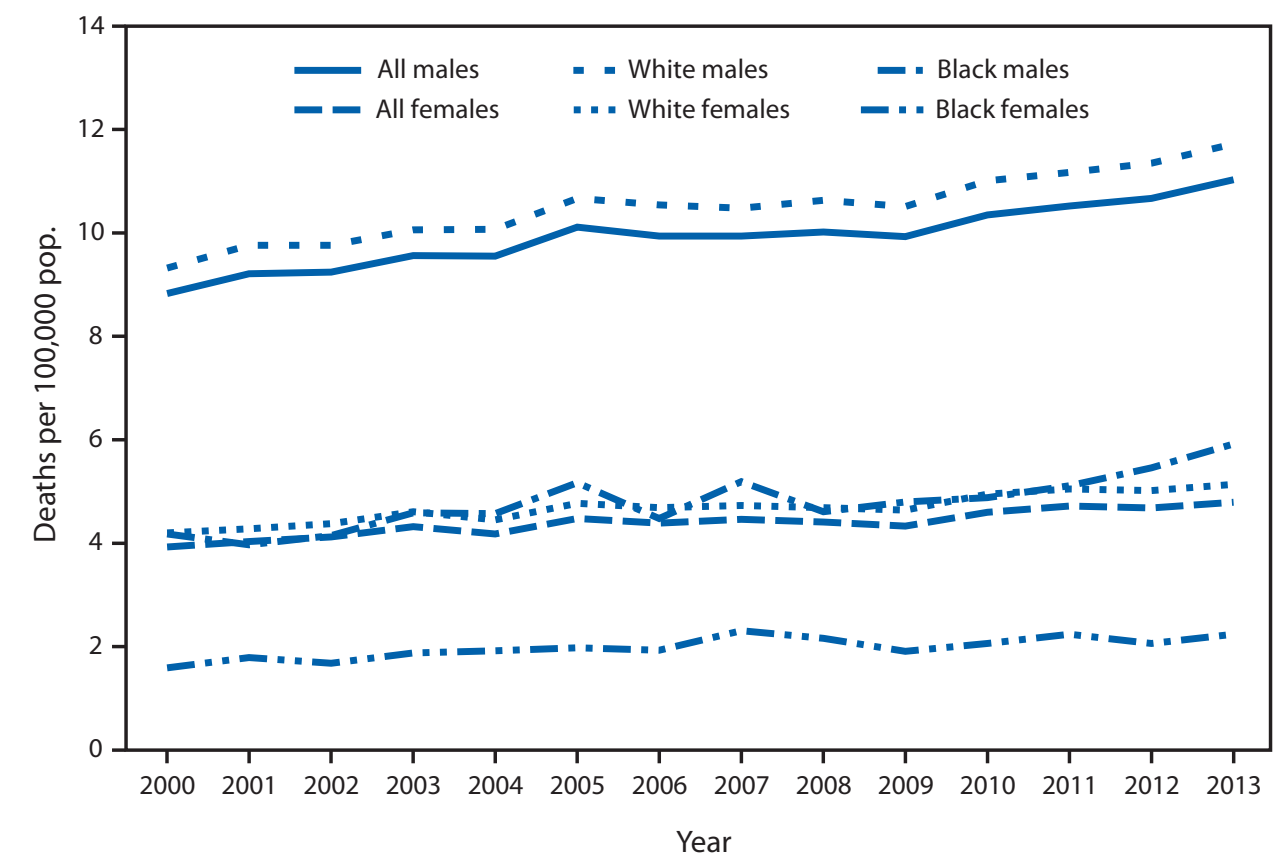

* Deaths per 100,000 standard population (year 2000).

† Deaths for Parkinson disease are identified using underlying cause of death with codes G20 and G21 in the International Classification of Disease, Tenth Revision.

The age-adjusted death rates for Parkinson disease increased for males from 8.8 per 100,000 population in 2000 to 11.0 in 2013 and for females from 3.9 in 2000 to 4.8 in 2013. From 2000 to 2013, the rates increased for black and white males and black and white females. Throughout the period, the rate for males was higher than the rate for females and the rates for whites were higher than those for blacks.

Source: National Vital Statistics System. Mortality public use data files, 2000-2013. Available at http://www.cdc.gov/nchs/data_access/ vitalstatsonline.htm.

Reported by: Jiaquan Xu, MD, jax4@cdc.gov, 301-458-4086. 

The Morbidity and Mortality Weekly Report (MMWR) Series is prepared by the Centers for Disease Control and Prevention (CDC) and is available free of charge in electronic format. To receive an electronic copy each week, visit MMWR's free subscription page at http://www.cdc.gov/mmwr/mmwrsubscribe.html. Paper copy subscriptions are available through the Superintendent of Documents, U.S. Government Printing Office, Washington, DC 20402; telephone 202-512-1800.

Readers who have difficulty accessing this PDF file may access the HTML file at http://www.cdc.gov/mmwr/index2015.html. Address all inquiries about the MMWR Series, including material to be considered for publication, to Executive Editor, MMWR Series, Mailstop E-90, CDC, 1600 Clifton Rd., N.E., Atlanta, GA 30329-4027 or to mmwrq@cdc.gov.

All material in the MMWR Series is in the public domain and may be used and reprinted without permission; citation as to source, however, is appreciated. Use of trade names and commercial sources is for identification only and does not imply endorsement by the U.S. Department of Health and Human Services.

References to non-CDC sites on the Internet are provided as a service to $M M W R$ readers and do not constitute or imply endorsement of these organizations or their programs by CDC or the U.S. Department of Health and Human Services. CDC is not responsible for the content of these sites. URL addresses listed in $M M W R$ were current as of the date of publication.

ISSN: 0149-2195 